INTERNATIONAL MONETARY FUND

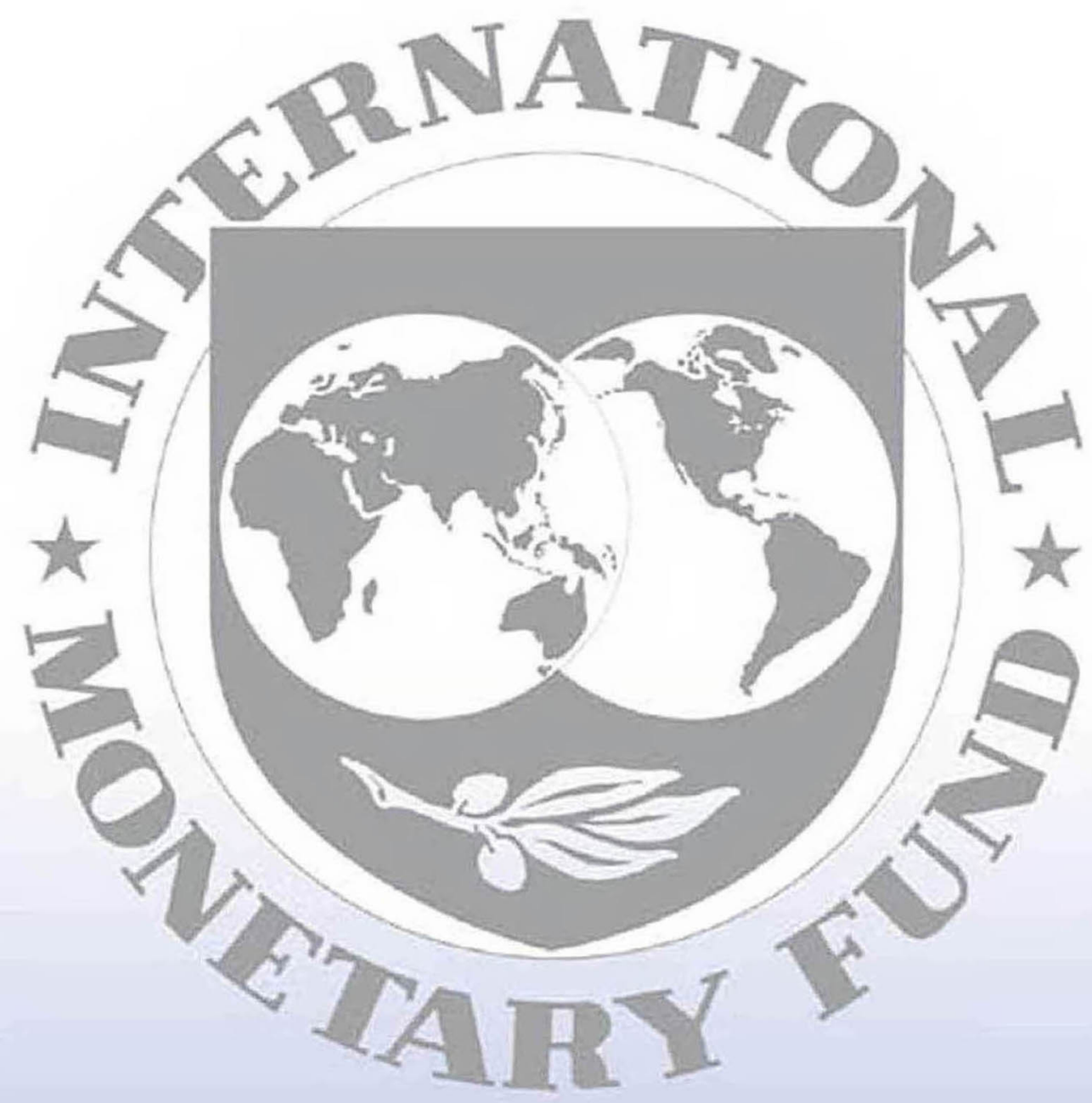

Staff

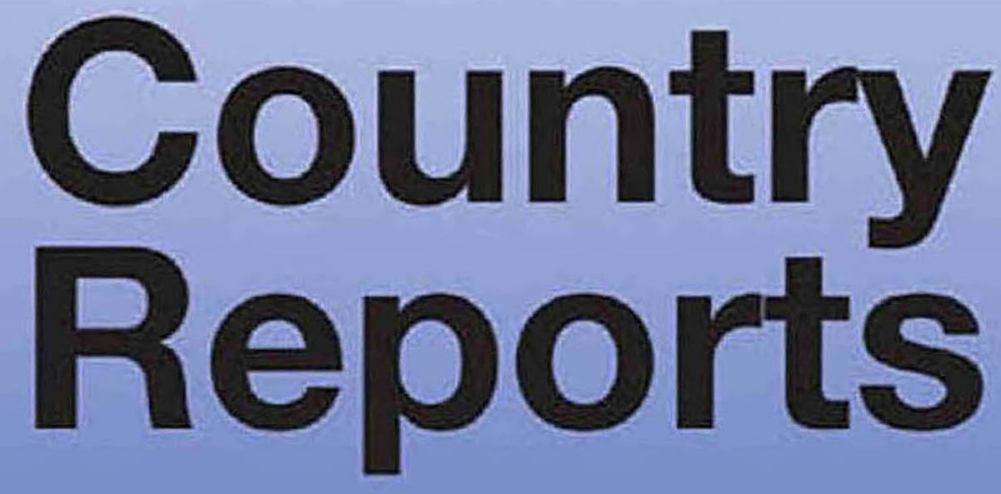




\section{Bosnia and Herzegovina: Second Review Under the Stand-By Arrangement and Requests for Waivers of Applicability and Modification of Performance Criteria - Staff Report; Press Release; and Statement by the Executive Director}

The following documents have been released and are included in this package:

- $\quad$ The staff report, prepared by a staff team of the IMF, following discussions that ended on February 26, 2013 with the officials of Bosnia and Herzegovina on economic developments and policies. Based on information available at the time of these discussions, the staff report was completed on April 23, 2013. The views expressed in the staff report are those of the staff team and do not necessarily reflect the views of the Executive Board of the IMF.

- $\quad$ A Press Release.

- $\quad$ A statement by the Executive Director for Bosnia and Herzegovina.

The document(s) listed below will be separately released.

Letter of Intent sent to the IMF by the authorities of Bosnia and Herzegovina* Technical Memorandum of Understanding*

*Also included in Staff Report

The policy of publication of staff reports and other documents allows for the deletion of market-sensitive information.

Copies of this report are available to the public from

International Monetary Fund • Publication Services

$70019^{\text {th }}$ Street, N.W. $\bullet$ Washington, D.C. 20431

Telephone: (202) 623-7430 • Telefax: (202) 623-7201

E-mail: publications@imf.org Internet: http://www.imf.org

\section{International Monetary Fund Washington, D.C.}




\section{INTERNATIONAL MONETARY FUND}

April 23, 2013

\section{BOSNIA AND HERZEGOVINA}

\section{SECOND REVIEW UNDER THE STAND-BY ARRANGEMENT AND REQUESTS FOR WAIVERS OF APPLICABILITY AND MODIFICATION OF PERFORMANCE CRITERIA}

\section{KEY ISSUES}

Stand-By Arrangement (SBA): The IMF Executive Board approved Bosnia and Herzegovina's $(\mathrm{BiH})$ request for a two-year SBA with access of SDR 338.2 million (200 percent of quota) on September 26, 2012. The first review was completed on December 19, 2012. SDR 101.46 million (60 percent of quota) has been disbursed so far and SDR 33.82 million (20 percent of quota) would become available after completion of the second review.

Program Performance: The second review was delayed to ensure passage in the Federation of a critical new law on privileged pensions that is more equitable and financially sustainable. As a result, this review should ideally be based on the now controlling end-March performance criteria, but data to assess all of these are not yet available. While the end-March performance criteria on contracting or guaranteeing new non-concessional debt and external payment arrears were both met, the authorities request waivers of applicability for the end-March performance criteria for which data are not yet available. Meanwhile, all end-2012 performance criteria were met, except that data to assess the criterion on the non-accumulation of domestic arrears by the general governments of the Federation and the Republika Srpska are not yet available, due to delays in data reporting by lower levels of government. In light of these reporting difficulties, the authorities request that going forward this performance criterion be modified to only apply to the Institutions of $\mathrm{BiH}$ and the central governments of the Federation and the Republika Srpska, while establishing indicative targets for the general governments of the Federation and the Republika Srpska. Progress was made in implementing structural measures, although several structural benchmarks were delayed and some are still in the process of obtaining parliamentary approval.

Outlook and risks: Following a mild recession in 2012, a modest recovery is projected for 2013. The external outlook remains clouded, but appears to have improved in recent months.

Domestic political risks loom large, however, and could complicate the timely implementation of key measures envisaged under the program.

Staff's view: On the basis of the performance so far and the authorities' economic policies for 2013, staff recommends the completion of the second review. Staff also supports the requests for waivers of applicability and modification of a performance criterion. 
Approved By

Aasim M. Husain and

Masato Miyazaki
A staff team comprising Messrs. van Rooden (head), Zhan, Llaudes (all EUR), Ms. Richmond, and Mr. Kapsoli (both FAD) visited Sarajevo and Banja Luka during February 13-26, 2013. Mr. Atoyan (resident representative) and local staff assisted the mission. Mr. Friedman (OED) attended most policy meetings. The team met with: at the State level: Central Bank Governor Kozarić and Deputy Minister of Finance and Treasury Đapo; in the Federation of BiH: Prime Minister Nikšić and Finance Minister Krajina; and in the Republika Srpska: Prime Minister Džombić and Finance Minister Tegeltija. Staff also met with other senior officials, members of the Federation of BiH parliament, and representatives of labor unions, the corporate sector, and the diplomatic community. Ms. Blasco and Ms. Nguyen (both EUR) assisted with the preparation of this report.

\section{CONTENTS}

RECENT DEVELOPMENTS, OUTLOOK, AND RISKS

POLICY DISCUSSIONS

A. Continued Fiscal Consolidation 7

B. Advancing Public Sector Reforms $\underline{8}$

C. Ensuring Financial Sector Stability $\underline{12}$

D. Enhancing Private Sector Development $\underline{14}$

E. Program Issues $\underline{16}$

STAFF APPRAISAL $\underline{16}$

\section{BOXES}

1. The Federation of BiH: Privileged Pensions

2. Republika Srpska: Reform of War Veteran Pensions

\section{FIGURES}

1. BiH: Selected Economic Indicators, 2007-14 


\section{TABLES}

1. Selected Economic Indicators, 2010-18 __

2. Real Sector Developments, 2010-18 __ 19

3. Balance of Payments, 2010-18__ $\underline{20}$

4. General Government Statement of Operations, 2010-18__ 21

5. General Government Statement of Operations, 2010-14_ 22

5a. Institutions of Bosnia and Herzegovina: Statement of Operations, 2010-14__ $\underline{23}$

5b. Federation of Bosnia and Herzegovina: General Government Statement of Operations, 2010-14

5c. Federation of Bosnia and Herzegovina: Central Government Statement of Operations, 2010-14 $\underline{25}$

5d. Republika Srpska: General Government Statement of Operations, 2010-14 $\underline{26}$

5e. Republika Srpska: Consolidated Central Government Statement of Operations, 2010-14 $\underline{27}$

6. Monetary Survey, 2010-14 __ $\underline{28}$

7. Schedule of Purchases Under the Stand-By Arrangement, 2012-14__ 29

8. Quantitative Performance Criteria and Indicative Target Under the 2012-14 Stand-By Arrangement, 2012-13__ $\underline{30}$

9. Structural Conditionality __ $\underline{31}$

10. Indicators of Capacity to Repay the Fund, 2011-19__ $\underline{32}$

11a. Gross Financing Requirements, 2013-18 (In millions of euros) ___

11b. Gross Financing Requirements, 2013-18 (In percent of GDP) __

12. Financial Soundness Indicators, 2008-12 __ 34

\section{APPENDIX}

I. Supplementary Letter of Intent

\section{ATTACHMENT}

1. Addendum to the Technical Memorandum of Understanding on

Definitions and Reporting Under the 2012-14 Stand-By Arrangement $\underline{45}$ 


\section{RECENT DEVELOPMENTS, OUTLOOK, AND RISKS}

\section{After two years of modest recovery, Bosnia and Herzegovina's (BiH) real GDP}

contracted in 2012. Economic activity remained weak in the last months of 2012. Staff estimates that real GDP contracted by about $1 / 2-1$ percent in 2012. Industrial production continued to decline, although appearing to bottom-out. Credit to the private sector grew only modestly-3 percent for 2012 as a whole-as banks have tightened lending standards and demand for credit remained subdued. Reflecting general weakness in European countries, exports from BiH fell by $4 \frac{1}{2}$ percent in 2012. This, together with a more modest decline in imports, led to a widening of the current account deficit to almost 10 percent of GDP. Inflation remained well contained at around 2 percent, despite higher food and energy prices, with core inflation low at around $1 / 2$ percent. Central bank reserves, boosted by Fund and EU disbursements and strengthened confidence, reached the highest level since the global financial $\mathrm{BiH}$ : Selected High-Frequency Indicators, 2011-13

\begin{tabular}{lrrrrrr}
\hline \multicolumn{1}{c}{ Indicator } & Dec-11 & Mar-12 & Jun-12 & Sep-12 & Dec-12 & Mar-13 \\
\hline & \multicolumn{7}{c}{ (Change, ytd, percent unless otherwise noted) } \\
& 0.0 & -0.9 & -0.6 & -0.9 & -0.6 & $\ldots$ \\
RS Real GDP & & & & & & \\
Industrial production (real) & 3.2 & -6.0 & -4.4 & -4.6 & -4.3 & 6.3 \\
$\quad$ Capital Goods & -3.2 & -16.9 & -8.3 & -1.0 & -0.5 & 36.9 \\
Private sector employment & -1.3 & -1.7 & -1.6 & -1.7 & -1.8 & -1.8 \\
Value-added tax revenues (gross) & 6.3 & -0.6 & -1.5 & 0.2 & -0.1 & 0.6 \\
Real net private sector wage & -1.2 & -0.4 & -0.7 & -0.8 & -4.5 & -1.4 \\
Imports (nominal), of which & 14.0 & 0.2 & -0.7 & -0.3 & -1.8 & 10.8 \\
$\quad$ Capital goods & 12.9 & -1.5 & 0.4 & -1.2 & -3.6 & 0.0 \\
$\quad$ Consumer non-durables & 6.3 & -1.5 & 0.0 & 1.5 & 1.7 & 6.3 \\
Exports (nominal) & 15.9 & -10.6 & -5.1 & -4.7 & -4.4 & 15.7 \\
Headline inflation & 3.7 & 2.3 & 2.2 & 2.1 & 2.0 & 1.0 \\
Core inflation & 0.3 & 0.6 & 0.6 & 0.6 & 0.6 & 0.2 \\
\hline
\end{tabular}

Sources: BiH authorities; and IMF staff estimates.

${ }^{1}$ Percent change over the same quarter in previous year.

${ }^{2}$ March 2013 or the latest available preliminary data. crisis in early 2013.

\section{With external and domestic demand likely to remain weak and no room for domestic} stimulus, modest growth is projected for 2013. The latest data on exports and industrial production suggest that economic activity is bottoming out, consistent with a modest recovery in 2013. Staff expects real GDP to expand by around $1 / 2$ percent, mainly benefiting from reduced stress in the euro area and a number of investment projects in the road and mining sectors, as well as a less harsh winter season and higher water levels that benefit hydro power generation. Inflation is expected to remain low at around 2 percent. The current account deficit is projected to narrow slightly, but to remain in the high single digits, financed largely by official flows and foreign direct investment.

3. Risks to the outlook remain significant. A challenging political situation poses significant risks to the timely implementation of policies envisaged under the program. Attempts to reshuffle the Federation government to reflect a shift in the parliamentary majority have met with legal obstacles and the ensuing impasse has made it difficult for the government to take major decisions. In the Republika Srpska, the prime minister and several ministers were replaced in late February in an effort to respond to growing discontent among the population about the weak economy. On the external front, while global market sentiment has improved, a re-intensification of the euro area crisis would significantly affect BiH's growth outlook. On the upside, a faster recovery in BiH's EU trading partners may boost external demand and private capital inflows. This, along with accelerated implementation of foreign-financed infrastructure projects, could support a faster upturn. 


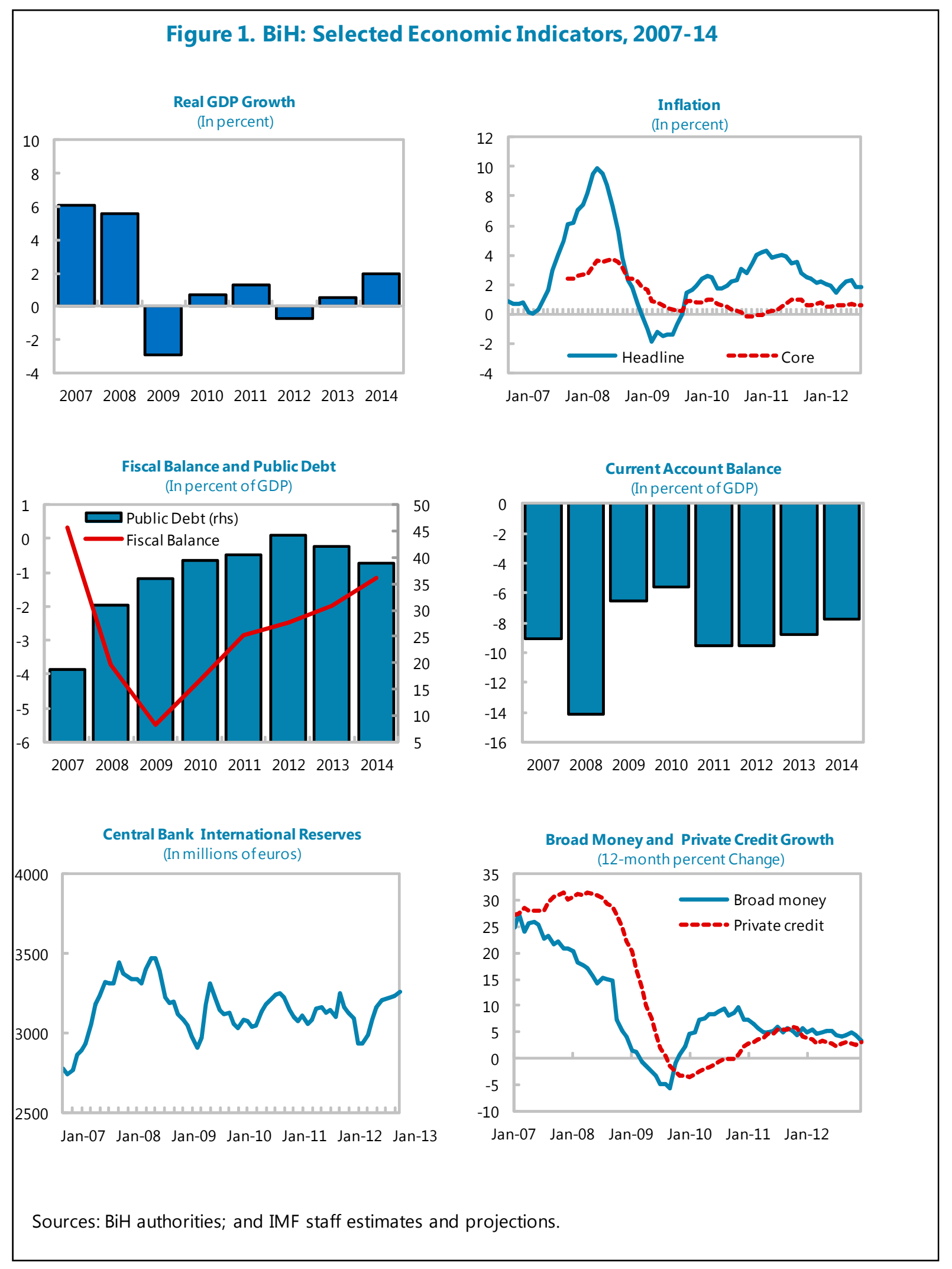




\section{PERFORMANCE UNDER THE PROGRAM}

4. Data to assess the end-March 2013 fiscal balances (net lending) and domestic arrears performance criteria are not yet available. There is no indication, however, that these performance criteria were not met. The authorities are therefore requesting waivers of applicability of these end-March performance criteria. Data are available for the end-March performance criteria on non-concessional short-term external debt and the continuous performance criterion on external payment arrears. The authorities did not contract or guarantee any new non-concessional shortterm external debt, nor did they accumulate any external payment arrears.

5. All end-2012 performance criteria on fiscal balances were met. Although revenues were slightly less than forecasted, strict expenditure control and an under-execution of investment projects at the central government level allowed for the end-year deficit targets to be met with comfortable margins.

6. The end-2012 general government overall deficit-an indicative target-appears to have been met based on available data. Prior to September 2012, expenditures by some parts of the general government, in particular the Federation Highway Fund and the Republika Srpska Health Fund, had been running ahead of financial plans. This trend was subsequently reversed, thanks to closer monitoring by the entity central governments and limited available financing. While final endyear data for the lower levels of government and public companies will only become available in the coming months, preliminary data suggest that the consolidated general government deficit narrowed to about $2 \frac{1}{2}$ percent of GDP in 2012 , half a percentage-point lower than envisaged at the time of the program request.

7. The determination of whether all components of the end-2012 performance criterion on the non-accumulation of domestic arrears were met is hampered by data lags. While the Institutions of $\mathrm{BiH}$, and the central governments of the Federation and the Republika Srpska did not accumulate any new arrears in 2012, complete data are not yet available for the general governments of the Federation and the Republika Srpska. Final end-year data have yet to become available for lower levels of government, extra-budgetary funds, and public companies. Given the long lags in data submission by lower levels of government, the authorities request that for endJune 2013 and going forward this performance criterion be modified to apply only to the Institutions of $\mathrm{BiH}$ and to the central governments of the Federation and the Republika Srpska. To ensure full coverage, they also propose to establish indicative ceilings on changes in "other accounts payable" for the general governments of the Federation and the Republika Srpska to align program targets directly to the reporting framework. In addition, the authorities are seeking technical assistance from the Fund to improve the timeliness and quality of fiscal reporting by lower levels of government, extra-budgetary funds, and public companies.

8. Steady albeit slower-than-planned progress was made toward implementing structural benchmarks. Most structural benchmarks were observed, although many with delays, while some are still awaiting parliamentary approval. The authorities continued to adhere to the currency board 
arrangement, and did not introduce any new privileged or special rights for retirement. ${ }^{1}$ The eligibility audits of war-benefit recipients continued and the summary reports for the fourth quarter of 2012 were posted on government web sites. Both the Federation and the Republika Srpska completed the payments-funded by a transfer from the Institutions of $\mathrm{BiH}$ budget-of accrued rights to decommissioned soldiers whose benefits had been repealed at the level of the Institutions of $\mathrm{BiH}$. Inter-entity payments to settle disputes through June 2012 regarding the allocation of indirect tax revenues were also completed. Amendments to the Law on Financing of the Institutions of $\mathrm{BiH}$, to ensure debt servicing in the absence of an approved budget, were adopted in April, and a Memorandum of Understanding (MOU) that regulates financial transactions with the IMF was signed by the central bank, the state and entity finance ministries, and the Indirect Taxation Authority (ITA). To align treatment of confidential information with EU standards, the Federation amended relevant legislation, while this process is expected to be finalized in the Republika Srpska before end-June. Similarly, amendments to the banking laws to limit the period of provisional administration are also awaiting approval by the entity parliaments, which is also expected in the coming months, with the delays reflecting a heavy legislative agenda. A new comprehensive law on privileged pensions was adopted in the Federation as a prior action for the completion of this review (see below).

\section{POLICY DISCUSSIONS}

\section{With the authorities' economic program broadly on track, policy discussions focused} on mitigating risks and stimulating private sector development. Policies are geared toward further fiscal consolidation, with an increasing focus on structural fiscal reforms; safeguarding financial sector stability through strengthening the legal and regulatory framework and enhancing capacity for bank supervision and crisis resolution; and creating a vibrant private sector that can provide more jobs by improving the business environment. The attached supplementary Letter of Intent describes the authorities' progress in implementing their economic program and additional policy measures for the remainder of 2013.

\section{A. Continued Fiscal Consolidation}

\section{Fiscal policy in $\mathbf{2 0 1 3}$ targets a further} reduction in the general government deficit to 2 percent of GDP. Budgets for 2013 for the Institutions of $\mathrm{BiH}$ and the central governments of the Federation and the Republika Srpska consistent with this objective were adopted in early December 2012. The further decline in the deficit-

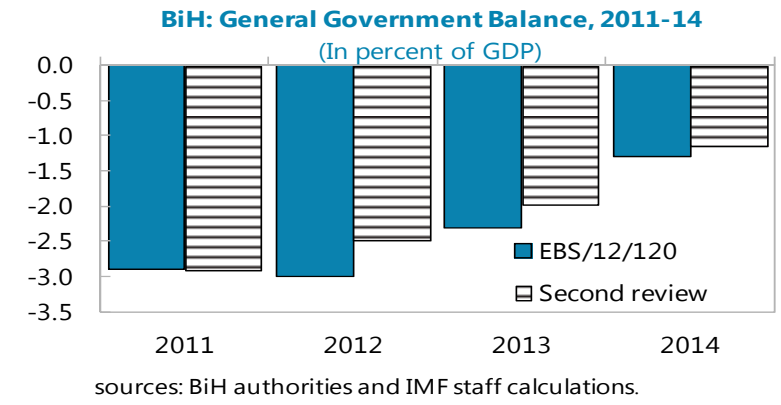

sources: BiH authorities and IMF staff calculations.

\footnotetext{
${ }^{1}$ The Federation parliament adopted a decision in late February confirming that a group of demobilized soldiers with two years or more of war participation would be covered under the new law on privileged pensions that was subsequently adopted in April. The RS had to provide budget resources to its pension fund to bridge the gap for a small group of officers retiring under existing law from the current Army of BiH until they become eligible for regular old-age pensions.
} 
striking a difficult balance between the need to ensure fiscal sustainability and support growth-is mainly achieved by curtailing current spending, notably the wage bill, but is also helped by an expected one-off dividend payment from the public electricity distribution company TRANSCO.

\section{The authorities agreed with the need to strictly adhere to the $\mathbf{2 0 1 3}$ spending}

envelopes. They acknowledged that financing constraints and sustainability considerations imply that there is no room for domestic stimulus. Downside risks to the economy are substantial, however, and while the budgets have been based on conservative revenue assumptions, automatic stabilizers could be allowed to work to some extent on the revenue side if these risks were to materialize. In that case, allowing the overall deficit to temporarily remain at close to $2 \frac{1}{2}$ percent of GDP would not materially alter BiH's medium-term debt outlook. In the event of a sharper downturn, possible contingency measures discussed with the authorities include a reduction in benefit levels, and delaying capital spending. On the other hand, should the economy grow faster than envisaged and revenues were to over-perform, adhering to the expenditure envelopes would allow for a faster reduction in the overall deficit.

\section{B. Advancing Public Sector Reforms}

\section{The authorities are gradually moving away from across-the-board spending cuts} toward structural fiscal reforms. Across-the-board austerity measures, such as freezing or even reducing government wages and reducing benefit levels, have approached their limits in terms of political and social tolerance. To make fiscal consolidation efforts more sustainable and more growth-friendly, consolidation efforts will need to focus on streamlining the size and structure of the government-including its wage structure-and further reform of entitlement programs, including pensions, health-care, and war-related benefits. Achieving structural savings in current spending will also help to create room for much-needed investment in infrastructure and human capital.

13. Substantial strides have been made in reforming war-related benefits. Benefits to veterans and demobilized soldiers, so-called privileged pensions, have risen in numbers and budgetary costs in recent years, especially in the Federation (Box 1). Benefit levels were substantially higher than regular pensions and allowed some veterans to retire at a relatively young age, discouraging labor market participation. Moreover, regular pension contributions have been used at times to fund these privileged pensions, undermining the financial health of the entity pension funds. The Republika Srpska implemented a major reform of its privileged pension system in early 2012 (Box 2) and a similar overhaul was implemented recently in the Federation: in consultation with Fund and World Bank staff, a new law on privileged pensions was adopted (a prior action for the completion of this review) with the aim to improve social fairness and contain the fiscal costs, including by:

- $\quad$ Separating the contributory portion of pensions from the privileged portion. Pension fund obligations will cover only pension entitlements based on beneficiaries' age and years of service, while any form of special benefits beyond that will be paid from the Federation central government budget; 


\section{Box 1. The Federation of BiH: Privileged Pensions}

Both Entities in $\mathrm{BiH}$ have introduced extensive benefit programs for participants in the 1992-95 war and to compensate individuals_as well as their families_for physical suffering. Among these benefits are privileged pensions, under which former soldiers are eligible for higher pensions or even early retirement. Given the size of the veteran population and a difficult political situation, the Federation has been facing major challenges to contain these privileged pensions.

A growing number of beneficiaries. Since 2004, the number of beneficiaries of privileged pensions in the Federation has increased seven fold, with the largest jumps taking place in 2007-09, largely financed by the VAT introduction in 2006 amid high economic growth prior to the global crisis. By December 2012, the number of beneficiaries had reached 23,400 (about 4 percent of the labor force) at an annual budgetary cost of 1.2 percent of Federation GDP.

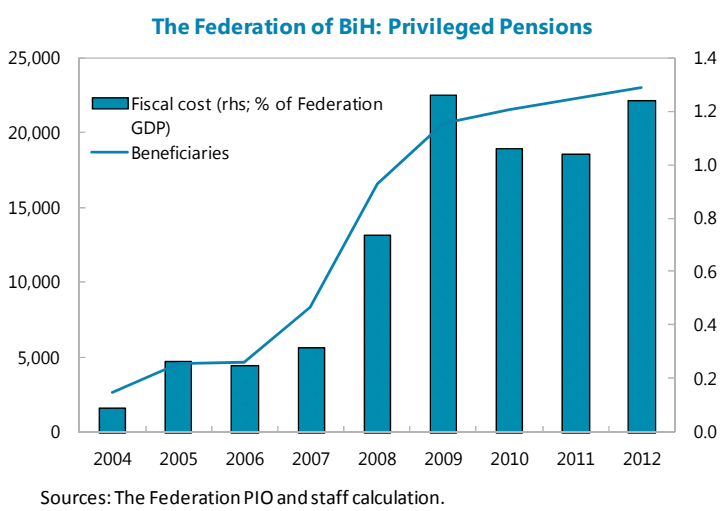

The Federation of $\mathrm{BiH}$ : Averages of Privileged Pensions

\begin{tabular}{|c|c|c|c|c|}
\hline \multirow[t]{2}{*}{ Categories } & \multicolumn{2}{|c|}{ March 2013} & \multicolumn{2}{|c|}{ Projected after the reform } \\
\hline & Beneficiaries & $\mathrm{KM} /$ month & Beneficiaries & $\mathrm{KM} /$ month \\
\hline Law on Confirming of Rights & 10,353 & 677 & 10,635 & 479 \\
\hline Decree 1 & 847 & 966 & 852 & 664 \\
\hline Decree 2 & 4,194 & 608 & 4,298 & 435 \\
\hline Decree 3 & 5,312 & 686 & 5,485 & 486 \\
\hline Demobilized soldiers $1 /$ & 8,939 & 279 & 8,939 & 279 \\
\hline War veterans and families 1 / & 3,451 & 260 & 3,451 & 260 \\
\hline Others & 321 & 754 & 321 & 754 \\
\hline New beneficiaries & & & about 6000 & about 311 \\
\hline \multicolumn{5}{|l|}{ Memo item: } \\
\hline Average regular pensions & & 341 & & 341 \\
\hline
\end{tabular}

Sources: The Federation authorities and staff calculation.

$1 /$ The Federation government makes additional transfers to bring the payments to these groups to the minimum pension level.

A complicated and unfair system. Privileged pensions are perceived as socially unjust because their level is on average 35 percent higher (close to 200 percent higher in some cases) than regular contributory pensions, which require contribution throughout working years and become payable only at age 65 for most people. In addition, privileged pensions were regulated by a number of different laws, varying significantly in terms of benefit levels even for persons with similar war participation and working experiences.

Constant pressure on the pension fund. Privileged pensions are administered by the pension fund. Although the laws require that a fixed share of the costs of privileged pension should be met by transfers from the central government budget, this obligation has not always been respected. In 2009, the government transferred less than half of its obligations, forcing the pension fund to use its reserves to pay privileged pensions. The government has recently agreed to replenish the pension fund reserves, starting with the 2013 budget.

Limited progress in reforms. A lack of financing had forced the government to control the expense on privileged pensions in recent years. Nevertheless, measures so far had been across-the-board cuts through applying rationing coefficients to all privileged pensioners (for instance, the 10 percent cut under the 2009 SBA). Earlier attempts to rationalize the privileged pensions had stalled due to a lack of political will and strong resistance from veteran groups. 


\section{Box 2. Republika Srpska: Reform of War Veteran Pensions}

Prior to the 2012 reform, more than 37,000 war veterans were eligible for retirement under special conditions. They were guaranteed monthly pensions, which in most cases were significantly higher than what would have earned based on years of service. In addition, war veterans benefited from an accelerated retirement scheme where one year of war participation was counted as two years of work history, allowing them to retire early. These features necessitated sizable budget transfers in order to protect the financial soundness of the pension fund as these pension benefits were not fully backed by contributions. They also encouraged early withdrawal from the formal labor market and working in the grey economy since only retired veterans were eligible for the benefits, while working veterans with otherwise similar characteristics were not. Despite efforts to tighten eligibility, the number of eligible veterans rose by 20 percent during $2008-11$, and the required monthly budget transfer based on the pension fund's calculation increased by about 16 percent in the same period.

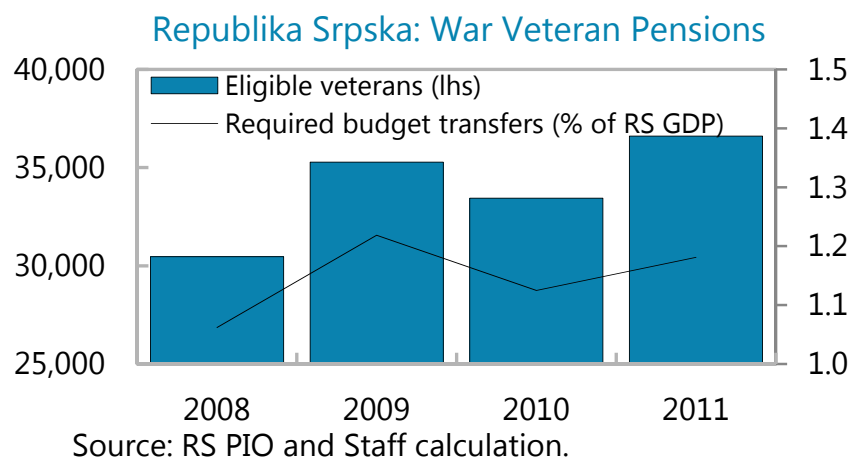

Effective January 1, 2012, a number of reform measures were introduced. The guaranteed higher pensions for veterans were abolished and pensions were to be calculated based on the same set of rules as regular pensioners, depending on age, years of service, and paid contributions, with the exception that every year of war participation still counts as two years of service. This resulted in a sizable reduction in monthly pension payments to veterans (on average by more than KM 100 per person). At the same time, a small monthly allowance for veterans 60 or older was introduced, which, regardless of the employment status of eligible veterans, is determined by an adjustable base (currently set at KM 1.6) and the duration of a beneficiary's war participation in months. As of end2012, over 50,000 veterans were eligible for this benefit, averaging KM 59 per month. An even smaller annual allowance (about KM 100) is paid to a group of veterans with the longest war participation until they reach 60 , after which they qualify for the monthly allowance.

Under the reformed system, a clear separation of contributory pensions paid by the pension fund and veteran allowances paid directly from the government budget helped improve budget transparency and the financial stability of the pension system. The new system also strengthened the government's control over its spending on veteran benefits as the base for the veterans' allowance is adjustable. While the accelerated retirement scheme was preserved, the new system removed the disincentives for labor market participation.

Despite covering a larger group of beneficiaries, the reform was designed to generate structural savings. Under pressure from veteran groups, however, a large part of these savings were used to provide temporary top-up payments to veterans whose overall benefit levels (i.e., the sum of pension and allowances) had been reduced the most. These additional payments are to be gradually phased out in the coming years. 
Harmonizing benefit levels across similar groups and reducing the average level of privileged pensions by 30 percent-bringing it much closer to the average level of contributory pensions - while adding penalties for early retirement. Further convergence toward the average level of regular pensions will be achieved by limiting the annual increase in individual benefits to less than the rate of inflation;

Adding benefits for segments of the veteran population in need of support. The reduction in benefit levels allowed for the inclusion of a sizable group of new beneficiaries, who, in the authorities' view, were unfairly excluded previously, including veterans who were disabled during the war and are currently unemployed and unemployed veterans close to the official retirement age. Also included was a group of decommissioned soldiers of the army of $\mathrm{BiH}$ whose benefits had been repealed at the state level, to ensure equal treatment with similar groups of veterans that had been granted benefits in the Federation. All new beneficiaries will receive only the minimum pension;

- Closing the system. Existing beneficiaries who had not already been audited will need to recertify their eligibility within the next four months, thus completing the audit process. Applications for benefits under the new categories will also need to be received before December 1, 2013 and no new applicants will be accepted after that date for any but two categories; ${ }^{2}$

- L Limiting the total budgetary costs to the amount included in the 2013 Federation central government budget and continuing to allow for the use of a rationing coefficient to guarantee that privileged pension payments remain within the overall budget allocation.

The new law is expected to generate some modest savings for the budget, while providing stronger safeguards for the financial health of the regular pension system. While the system will be closed, strong political will will continue to be required not to re-open it in the years ahead.

\section{The Federation authorities are close to finalizing a strategy for the reform of old-age} pensions. Given the challenging demographics, pension reform is imperative to ensure the longerterm sustainability of the system. The key objective of the reform will be to encourage workers to stay longer in the labor force and increase the number of contributors. The strategy envisages a gradual increase in the retirement age, in line with similar reforms adopted in the Republika Srpska in late 2011. The authorities plan to submit this strategy, together with an action plan, for discussion to parliament in May 2013.

15. The authorities recognize the need to address the rising costs of health care. In recent years, and notably in the Republika Srpska, health care costs have risen steadily due to the growing number of unemployed and pensioners. In the near term, the Republika Srpska authorities are trying to contain health care spending by reducing inefficiencies and administrative costs, including

\footnotetext{
${ }^{2}$ Veterans with at least three years of war participation and who have been at least one year unemployed will remain eligible once they reach 59, while a small group of former police commanders has until end-2015 to apply in order not to force them into early retirement.
} 
through wage cuts and by consolidating health care institutions and reviewing coverage levels. They have also requested the assistance of the World Bank to develop a strategy to ensure the sustainability of health care finances over the longer term.

\section{Controls over spending by lower level governments, extra-budgetary funds, and} public companies are being strengthened. A new Budget System Law was adopted in the Republika Srpska in December 2012 that introduced penalty clauses for undertaking commitments that exceed budget allocations. The Federation, which has a more decentralized structure and weaker expenditure control by the central government, is also preparing a new law on budgets, with the assistance of the Fund, aimed at strengthening control over-and monitoring of - spending by lower levels of government, extra-budgetary funds, and public companies. Given the time needed to include Fund staff recommendations in the draft law its adoption is now expected by end-May (a proposed new deadline for the structural benchmark originally targeted to be implemented by endMarch). In the meantime, the Federation authorities are increasing the number of staff of the unit in the finance ministry responsible for the collection and consolidation of lower-level government data, and, as noted above, have requested further technical assistance to improve the quality and timeliness of fiscal reporting.

17. With most reforms focusing on reducing expenditures, steps are also being taken to improve tax compliance. In this context, the Institutions of $\mathrm{BiH}$, the entities, and the Brčko District will, through a MOU, formalize the procedure for the exchange of taxpayer information among the tax authorities (a structural benchmark for end-May 2013). In addition, the ITA, with the approval from its Governing Board, will better align its resources to the activities with high yield, including by shifting resources to the Large Taxpayer Unit and by establishing a strategy and risk analysis unit with the mandate of detecting and coordinating the activities for the prevention of VAT fraud.

\section{Ensuring Financial Sector Stability}

\section{The banking system is relatively stable, but lending remains muted and non-} performing loans are creeping up. Financial sector indicators through end-2012 suggest that the banking system — which is predominantly owned by Austrian and Italian banks-remains profitable and adequately capitalized at the aggregate level. However, the headwinds from weak domestic activity are being more pronouncedly felt. Non-performing loans (NPLS) have edged up further, to over 13 percent by end-2012 and could rise even more in the near future, although provisioning stands at 67 percent of non-performing assets. While the latest stress tests did not reveal major weaknesses in the system, the banking agencies have been quick to engage some smaller banks that presented tighter capital positions under severe shock scenarios. Parent banks' exposure to their subsidiaries declined only moderately over the last several quarters. The loan-to-deposit ratio remains relatively high at around 125 percent. Credit growth remains subdued, however, at 3 percent in 2012, reflecting banks applying tighter credit standards and the weak economy. 


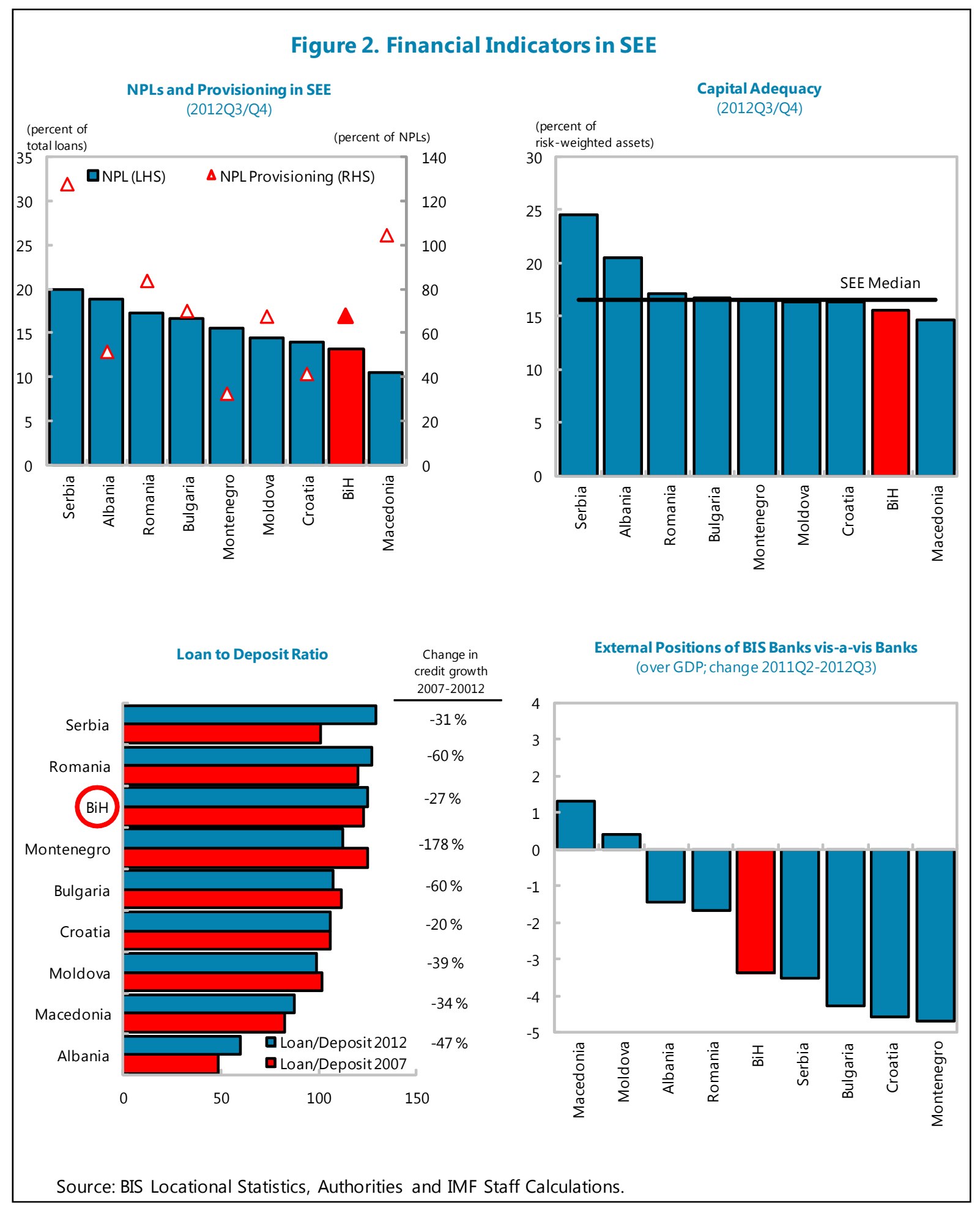




\section{Further progress is being made to strengthen bank supervision and the crisis resolution framework. Specifically:}

- The Federation authorities have amended the legal framework related to the treatment of confidential information to align it with EU requirements, while in the Republika Srpska this is awaiting parliamentary approval (an end-December 2012 structural benchmark that is now expected to be completed before end-June 2013, and which is the proposed new deadline for this benchmark). These changes would help to pave the way to sign MOUs with homecountry banking supervisors, aimed at enhancing cooperation. The authorities are also planning to host a cross-border forum in the near future, inviting home country supervisors and parent banks.

- Amendments to the entities' banking laws to limit the provisional administration of banks to one year, with a possible 6-month extension are also awaiting approval by the respective parliaments (structural benchmarks for end-December 2012 which are now expected to be completed before end-June 2013, which is also proposed as the new deadline for these benchmarks). A more comprehensive overhaul of both entities' banking laws is planned in order to fully harmonize them with EU legislation. This process is expected to be completed in the first half of 2014.

- $\quad$ A joint MOU between the Central Bank of Bosnia and Herzegovina ( $\mathrm{CBBH}$ ), and the banking agencies, which formalizes the procedures for top-down stress-testing has been prepared and was signed in mid March 2013.

- The authorities have established the criteria for identifying — and prepared a preliminary list of-those financial institutions that are considered systemically important and which will be subject to increased monitoring, including bottom-up stress tests.

- The authorities have requested Fund technical assistance to assess the NPL resolution framework and to identify steps to strengthen this framework by removing legal, tax, and institutional obstacles.

- The amendments to the law governing the DIA have been submitted to the BiH parliament. These amendments aim to ensure that: (i) coverage will be extended to small- and mediumsized enterprises; (ii) all banks will be members of the deposit insurance scheme, including those that may fall under provisional administration; and (iii) it is consistent with international standards (an end-March 2013 structural benchmark).

\section{Enhancing Private Sector Development}

20. The authorities are making progress in harmonizing agricultural export standards with EU requirements ahead of Croatia's accession to the EU. While the value of the affected agricultural exports is relatively limited, the sector provides many jobs. After initial delays due to political differences, improved policy coordination and cooperation has allowed work to proceed on a unified rule book on food and animal safety standards, which is expected to be completed in the 
coming months. Agreements have also been reached with Croatia and the EU that will allow BiH to continue to export to third countries via Croatia after July 2013.

21. Further EU integration still faces significant hurdles, however. The Stability and Association Agreement, signed in 2008, has yet to become effective pending implementation of election reforms, and only then could $\mathrm{BiH}$ submit an application for EU membership. A lack of coordination and differences in view about the role of the state have slowed progress, risking that $\mathrm{BiH}$ will increasingly lag behind its neighbors on the road toward EU integration.

\section{The authorities recognize the need to foster private sector development in order to} create more jobs. Unemployment-already high before the global crisis-has risen to 28 percent, with youth unemployment exceeding 60 percent, among the highest levels in the region. $\mathrm{BiH}$ lags regional peers in business environment indicators, and the large public sector, poor infrastructure, and labor market rigidities hamper the development of a vibrant private sector. To address these weaknesses, the authorities plan to take a multi-pronged approach in advancing labor market and regulatory reforms so as to improve job creation and enhance competitiveness, including:

Simplification of business registration and regulation. The process of creating a onestop shop for business registration is well under way in the Republika Srpska, and is expected to become operational by late this year. The Federation is preparing a new law on companies, also to simplify business registration and to improve corporate governance.

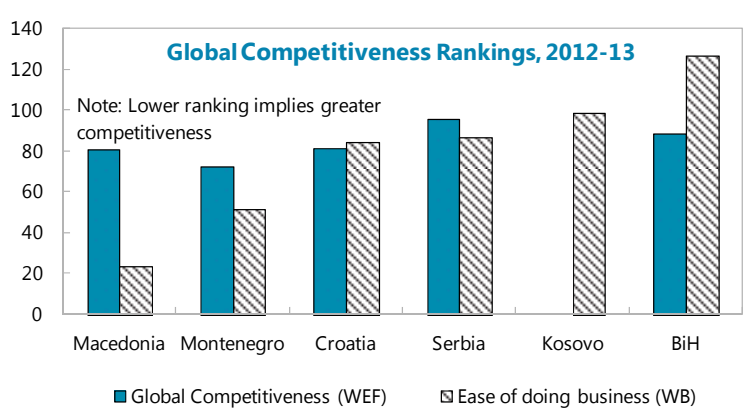

- Streamlining the tax and contribution payment procedures. The authorities of the Institutions of $\mathrm{BiH}$ have been working on enabling laws and regulations for digital signature and expect its application throughout $\mathrm{BiH}$ by early 2014. In the Federation, with a decentralized structure, taxes, fees, and employees' contributions presently have to be paid to different collection agencies, depending on residence and the purposes of the payments, which poses a significant burden for compliance, especially for small- and medium-sized enterprises. The Federation authorities, with help from USAID, are testing a more centralized collection and reporting system, with a view to streamlining this process and reducing compliance costs for businesses.

- $\quad$ Enhancing labor market legislation. The authorities in both entities will start the consultative process with trade unions and employers' organizations in preparation for amending the labor laws. The objective is to make it easier for employers to adjust staffing levels when circumstances change and shift workers from the grey economy to the formal sector. 


\section{E. Program Issues}

23. BiH has sufficient capacity to discharge its obligations to the Fund in a timely manner. By the end of the SBA, the level of Fund credit outstanding is projected to be slightly below 3 percent of GDP (121/4 percent of gross international reserves), and Fund repurchases and charges would peak at 41 percent of total debt service in 2013. The country so far has an excellent record of meeting Fund financial obligations. With the expectation that strong performance under the program will continue, BiH will return to a sustainable medium-term growth path. This provides assurances that $\mathrm{BiH}$ should continue to be able to service its obligations to the Fund on time.

24. The authorities have taken further measures to strengthen the external debt servicing framework. As noted above, the amendments to the Law on Financing of the Institutions of $\mathrm{BiH}$ were adopted to ensure that foreign debt obligations can be met even in the absence of an adopted budget (a structural benchmark for end-December 2012). In addition, the BiH Ministry of Finance and Treasury, entity Ministries of Finance, the ITA, and the $\mathrm{CBBH}$ signed a MOU to regulate the disbursements from and servicing of obligations to the Fund (a structural benchmark for endDecember 2012).

25. BiH joined the General Data Dissemination System (GDDS) in April. While data are generally adequate for surveillance and program monitoring and considerable progress has been made over the last few years to improve fiscal reporting in particular, weaknesses in the quality and timeliness of data remain. BiH's participation in the GDDS is an important milestone in the authorities' efforts to produce and disseminate more reliable and timely statistics.

\section{STAFF APPRAISAL}

26. The authorities of Bosnia and Herzegovina continue to make good progress under the SBA. Fiscal consolidation is proceeding at a faster pace than envisaged earlier, and its focus is gradually shifting to the structural fiscal reforms that could generate medium- to long-term savings, ensuring medium-term sustainability and creating much-needed space for investments in infrastructure and human capital. In the financial sector, the capacity to supervise banks and address potential difficulties has increased, mitigating risks. Data to assess all the controlling end-March 2013 performance criteria are not yet available, but the two for which data are available were met. Moreover, all end-2012 performance criteria-excluding the performance criterion on domestic arrears for which complete data is not available-were met, and steady progress has also been made in observing structural benchmarks, albeit with delays.

\section{The need to ensure medium-term fiscal sustainability leaves no room for fiscal}

stimulus. Despite the low rate of economic growth expected for 2013, it is critical to strictly adhere to the spending envelopes in the 2013 budgets. A slightly slower pace of fiscal consolidation could be allowed, however, should revenues disappoint due to weaker-than-expected growth. Conversely, should the economy grow faster than envisaged, adhering to the spending envelopes would allow for a faster pace of fiscal consolidation. 


\section{Ensuring medium-term fiscal sustainability also requires moving ahead with fiscal} structural reforms. Across-the-board spending cuts have reached their limits and further consolidation efforts will need to focus more on generating structural savings. The reform of warrelated benefit programs, first in the Republika Srpska and now also in the Federation, are welcome and bold steps. Other key areas for reform include streamlining the size and structure of the government and reducing the cost of health care.

29. BiH's banking sector remains stable, but continued vigilance is warranted. Further progress is being made in strengthening banking supervision, including by formalizing stress testing procedures and identifying systemically important institutions. Nevertheless, the rise in NPL warrants close monitoring of banks' health. The review of the NPL resolution framework will help the authorities define measures that would enable banks address their large portfolio of NPLs. Close coordination and cooperation with home country supervisors-given the ownership structure of the banking sector-remains crucial to ensure financial sector stability. The authorities are also urged to implement a number of delayed program benchmarks designed to strengthen the financial sector.

\section{Creating a vibrant private sector is key to creating more jobs and reducing}

unemployment. The authorities should move ahead rapidly with improving the business environment and enhancing labor market flexibility to make $\mathrm{BiH}$ a more attractive place to invest and increase competitiveness. Urgent action is also needed to avoid $\mathrm{BiH}$ falling behind further on the road toward EU integration.

31. Risks to the program remain large. While the external economic environment appears to have started to improve, a re-intensification of the euro area crisis remains a risk and would significantly affect BiH's economic outlook through its impact on exports, remittances, and capital flows. In addition, domestic political risks loom large and political instability could hamper program implementation and weaken support for key structural reforms.

\section{Despite these risks, in view of the authorities' good performance to date and their} policies for the remainder of $\mathbf{2 0 1 3}$ as summarized in the attached supplementary Letter of Intent of April 23, 2013, staff supports the authorities' request for the completion of the second review under the Stand-By Arrangement. Staff also supports the authorities' request for waivers of applicability of the end-March 2013 performance criteria on the floor on net lending (fiscal balances) and the ceiling on the accumulation of domestic arrears, as data are not yet available while there is no evidence that these were not met and the program is expected to be successfully implemented, and their request to modify the performance criterion on the nonaccumulation of domestic arrears for end-June 2013 and going forward. Against this backdrop, staff encourages the authorities to step up their efforts to improve the quality and timeliness of fiscal reporting by lower levels of government, with the assistance from the Fund. 


\begin{tabular}{|c|c|c|c|c|c|c|c|c|c|c|c|c|}
\hline & \multirow[t]{2}{*}{2010} & \multirow[t]{2}{*}{2011} & \multicolumn{3}{|c|}{2012} & \multicolumn{2}{|c|}{2013} & \multirow[t]{2}{*}{2014} & \multirow[t]{2}{*}{2015} & \multirow{2}{*}{$\begin{array}{l}2016 \\
\text { Proj. }\end{array}$} & \multirow[t]{2}{*}{2017} & \multirow[t]{2}{*}{2018} \\
\hline & & & $\mathrm{EBS} / 12 / 120$ & $\mathrm{EBS} / 12 / 161$ & Prel. & $\mathrm{EBS} / 12 / 161$ & Proj. & & & & & \\
\hline Nominal GDP (KM million) & 24,773 & 25,666 & 25,970 & 25,885 & 26,362 & 26,797 & 27,841 & 29,263 & 31,082 & 33,308 & 35,583 & 38,000 \\
\hline Gross national saving (in percent of GDP) & 12.2 & 6.9 & 10.9 & 9.0 & 6.5 & 10.0 & 7.3 & 8.5 & 9.6 & 10.6 & 11.7 & 12.9 \\
\hline Gross investment (in percent of GDP) & 17.1 & \multicolumn{10}{|c|}{ (Percent change) } & 17.9 \\
\hline Real GDP & 0.7 & 1.3 & 0.0 & -0.7 & -0.7 & 0.5 & 0.5 & 2.0 & 3.5 & 4.0 & 4.0 & 4.0 \\
\hline CPI (period average) & 2.1 & 3.7 & 2.2 & 2.5 & 2.0 & 2.4 & 1.8 & 1.8 & 1.9 & 2.0 & 2.2 & 2.2 \\
\hline \multicolumn{13}{|l|}{ Money and credit (end of period) } \\
\hline Broad money & 7.2 & 5.8 & 1.9 & 1.6 & 3.4 & 3.5 & 4.9 & 5.1 & 6.2 & 7.2 & 7.1 & 7.1 \\
\hline Credit to the private sector & 2.1 & 4.2 & 1.0 & 0.8 & 2.8 & 3.5 & 5.6 & 5.9 & 7.0 & 8.0 & 7.6 & 7.7 \\
\hline & \multicolumn{12}{|c|}{ (In percent of GDP) } \\
\hline \multicolumn{13}{|l|}{ Operations of the general government } \\
\hline Revenue & 46.9 & 46.6 & 46.5 & 46.4 & 45.7 & 46.3 & 44.5 & 44.8 & 44.9 & 45.0 & 45.2 & 45.3 \\
\hline Of which: grants & 2.4 & 2.1 & 2.1 & 2.2 & 2.2 & 2.2 & 2.1 & 2.1 & 2.2 & 2.3 & 2.5 & 2.6 \\
\hline Expenditure & 51.0 & 49.0 & 49.5 & 49.5 & 48.2 & 48.4 & 46.5 & 46.0 & 45.6 & 44.9 & 44.7 & 44.0 \\
\hline Of which: investment expenditure & 7.9 & 6.3 & 6.4 & 6.7 & 6.5 & 6.6 & 6.4 & 6.6 & 6.8 & 6.9 & 7.2 & 7.4 \\
\hline Net lending & -4.2 & -2.4 & -3.0 & -3.0 & -2.5 & -2.0 & -2.0 & -1.2 & -0.7 & 0.1 & 0.4 & 1.3 \\
\hline Net lending, excluding interest payment & -3.5 & -1.8 & -2.1 & -2.2 & -1.8 & -1.1 & -1.1 & -0.3 & 0.2 & 1.0 & 1.3 & 1.7 \\
\hline Total public debt & 39.3 & 40.4 & 43.1 & 43.9 & 44.3 & 43.0 & 42.1 & 39.4 & 37.0 & 34.2 & 31.5 & 31.2 \\
\hline Domestic public debt & 13.9 & 14.5 & 14.9 & 15.4 & 16.7 & 13.5 & 13.8 & 11.2 & 9.9 & 8.5 & 7.7 & 7.6 \\
\hline \multirow[t]{2}{*}{ External public debt } & 25.4 & 25.9 & 28.2 & 28.5 & 27.6 & 29.5 & 28.4 & 28.1 & 27.1 & 25.7 & 23.8 & 23.6 \\
\hline & \multicolumn{12}{|c|}{ (In millions of euros) } \\
\hline \multicolumn{13}{|l|}{ Balance of payments } \\
\hline Exports of goods and services & 3,701 & 4,106 & 5,471 & 3,953 & 3,921 & 4,265 & 4,118 & 4,462 & 4,815 & 5,178 & 5,591 & 5,970 \\
\hline Imports of goods and services & 6,522 & 7,714 & 8,539 & 7,264 & 7,041 & 7,573 & 7,445 & 7,858 & 8,297 & 8,774 & 9,322 & 9,830 \\
\hline Current transfers, net & 1,796 & 1,792 & 1,789 & 1,824 & 1,824 & 1,859 & 1,851 & 1,939 & 2,049 & 2,175 & 2,313 & 2,455 \\
\hline Current account balance & -702 & $-1,247$ & $-1,008$ & $-1,310$ & $-1,302$ & $-1,237$ & $-1,245$ & $-1,186$ & $-1,152$ & $-1,088$ & $-1,045$ & -977 \\
\hline (In percent of GDP) & -5.5 & -9.5 & -7.6 & -9.9 & -9.7 & -9.0 & -8.7 & -7.9 & -7.2 & -6.4 & -5.7 & -5.0 \\
\hline Foreign direct investment & -185.9 & -273.2 & 200.0 & -404.0 & -404.0 & -346.9 & -346.9 & -304.4 & -316.5 & -329.0 & -341.9 & -355.1 \\
\hline (In percent of GDP) & -1.5 & -2.1 & 1.5 & -3.1 & -3.0 & -2.5 & -2.4 & -2.0 & -2.0 & -1.9 & -1.9 & -1.8 \\
\hline Gross official reserves & 3,303 & 3,285 & 3,229 & 3,245 & 3,326 & 3,285 & 3,399 & 3,558 & 3,695 & 3,864 & 3,988 & 4,337 \\
\hline (In months of imports) & 5.4 & 5.5 & 4.3 & 5.1 & 5.4 & 5.0 & 5.2 & 5.2 & 5.1 & 5.0 & 4.9 & 5.1 \\
\hline External debt, percent of GDP & 51.6 & 49.0 & 51.6 & 52.5 & 51.9 & 54.0 & 51.4 & 51.6 & 50.8 & 49.4 & 47.5 & 47.3 \\
\hline External debt service/GNFS exports (percent) & 19.7 & 14.9 & 9.8 & 13.2 & 13.1 & 17.4 & 17.2 & 17.4 & 15.7 & 15.2 & 16.9 & 11.2 \\
\hline
\end{tabular}




\begin{tabular}{|c|c|c|c|c|c|c|c|c|c|}
\hline \multicolumn{10}{|c|}{ Table 2. Bosnia and Herzegovina: Real Sector Developments, 2010-18 } \\
\hline & 2010 & 2011 & 2012 & 2013 & 2014 & 2015 & 2016 & 2017 & 2018 \\
\hline & & & Est. & \multicolumn{6}{|c|}{ Proj. } \\
\hline Real aggregates & \multicolumn{9}{|c|}{ (Percent change) } \\
\hline \multicolumn{10}{|l|}{ Growth rates } \\
\hline GDP at constant 2005 prices & 0.7 & 1.3 & -0.7 & 0.5 & 2.0 & 3.5 & 4.0 & 4.0 & 4.0 \\
\hline Domestic demand & -3.0 & 1.4 & -0.8 & 1.6 & 2.6 & 3.7 & 4.6 & 4.1 & 4.0 \\
\hline Private & -4.9 & 3.2 & -0.9 & 1.9 & 2.6 & 3.5 & 4.6 & 3.8 & 3.8 \\
\hline Public & 3.0 & -3.5 & -0.5 & 0.6 & 2.8 & 4.4 & 4.8 & 5.1 & 4.7 \\
\hline Consumption & 0.2 & 3.3 & -1.3 & 1.2 & 2.0 & 2.8 & 4.0 & 3.2 & 3.1 \\
\hline Private & -0.1 & 3.2 & -1.2 & 1.5 & 2.2 & 2.8 & 4.1 & 3.2 & 3.2 \\
\hline Public & 1.3 & 3.6 & -1.8 & 0.1 & 1.1 & 3.0 & 3.4 & 3.2 & 2.7 \\
\hline Gross capital formation & -15.9 & -7.7 & 2.3 & 3.7 & 6.2 & 8.0 & 7.7 & 8.2 & 8.2 \\
\hline Private & -29.2 & 3.2 & 1.5 & 4.7 & 5.2 & 7.7 & 7.4 & 7.1 & 7.5 \\
\hline Public & 7.5 & -20.4 & 3.6 & 2.1 & 7.6 & 8.4 & 8.3 & 9.8 & 9.2 \\
\hline \multicolumn{10}{|l|}{ Net Exports } \\
\hline Exports of goods and services & 10.1 & 3.3 & -7.5 & 6.7 & 9.3 & 7.9 & 6.6 & 6.7 & 5.4 \\
\hline Imports of goods and services & -2.6 & 2.8 & -4.8 & 6.3 & 7.4 & 6.4 & 6.7 & 5.8 & 4.8 \\
\hline Contributions to real GDP growth & \multicolumn{9}{|c|}{ (Year-on-year change over real GDP in previous year, in percent) } \\
\hline GDP at constant 2005 prices & 0.7 & 1.3 & -0.7 & 0.5 & 2.0 & 3.5 & 4.0 & 4.0 & 4.0 \\
\hline Domestic demand & -3.8 & 1.8 & -1.0 & 2.0 & 3.3 & 4.7 & 5.9 & 5.3 & 5.2 \\
\hline Private & -4.8 & 2.9 & -0.8 & 1.8 & 2.5 & 3.3 & 4.4 & 3.7 & 3.6 \\
\hline Public & 1.0 & -1.1 & -0.2 & 0.2 & 0.9 & 1.4 & 1.5 & 1.6 & 1.5 \\
\hline Consumption & 0.2 & 3.4 & -1.4 & 1.3 & 2.1 & 3.0 & 4.2 & 3.4 & 3.2 \\
\hline Private & -0.1 & 2.6 & -1.0 & 1.3 & 1.8 & 2.3 & 3.4 & 2.7 & 2.6 \\
\hline Public & 0.3 & 0.8 & -0.4 & 0.0 & 0.3 & 0.7 & 0.8 & 0.7 & 0.6 \\
\hline Gross capital formation & -4.0 & -1.6 & 0.4 & 0.7 & 1.3 & 1.7 & 1.7 & 1.9 & 2.0 \\
\hline Private & -4.7 & 0.4 & 0.2 & 0.6 & 0.6 & 1.0 & 1.0 & 1.0 & 1.0 \\
\hline Public & 0.7 & -2.0 & 0.3 & 0.2 & 0.6 & 0.7 & 0.7 & 0.9 & 0.9 \\
\hline Net Exports & 4.6 & -0.5 & 0.3 & -1.5 & -1.3 & -1.2 & -1.9 & -1.3 & -1.2 \\
\hline Exports of goods and services & 3.0 & 1.1 & -2.5 & 2.0 & 3.0 & 2.8 & 2.4 & 2.5 & 2.1 \\
\hline Imports of goods and services & -1.6 & 1.6 & -2.8 & 3.5 & 4.4 & 4.0 & 4.3 & 3.8 & 3.2 \\
\hline Deflators & \multicolumn{9}{|c|}{ (Percent Change) } \\
\hline GDP & 1.6 & 2.3 & 3.4 & 5.1 & 3.0 & 2.6 & 3.0 & 2.7 & 2.7 \\
\hline Domestic demand & 3.6 & 4.1 & 3.6 & 2.9 & 1.8 & 1.8 & 1.8 & 2.1 & 2.1 \\
\hline Consumption & 3.2 & 3.8 & 3.8 & 3.2 & 2.6 & 2.1 & 2.1 & 2.4 & 2.5 \\
\hline Investment & 2.3 & 3.7 & 2.9 & 1.2 & 1.2 & 0.6 & 0.6 & 1.3 & 1.4 \\
\hline Exports of goods and services & 9.4 & 7.2 & 3.2 & -1.6 & -0.9 & 0.0 & 0.9 & 1.1 & 1.4 \\
\hline Imports of goods and services & 9.7 & 9.3 & 3.7 & -3.3 & -1.8 & -0.8 & -0.9 & 0.4 & 0.6 \\
\hline \multicolumn{10}{|l|}{ Nominal aggregates } \\
\hline \multirow[t]{2}{*}{ Nominal GDP (KM million) } & 24,773 & 25,666 & 26,362 & 27,841 & 29,263 & 31,082 & 33,308 & 35,583 & 38,000 \\
\hline & \multicolumn{9}{|c|}{ (In percent of GDP) } \\
\hline Consumption & 105.0 & 108.6 & 108.3 & 107.2 & 106.1 & 104.9 & 103.9 & 102.9 & 101.8 \\
\hline Private & 83.6 & 86.6 & 86.8 & 86.4 & 85.8 & 84.8 & 84.2 & 83.4 & 82.6 \\
\hline Public & 21.4 & 22.1 & 21.5 & 20.8 & 20.3 & 20.1 & 19.8 & 19.5 & 19.2 \\
\hline Gross capital formation & 17.1 & 15.8 & 16.2 & 16.1 & 16.4 & 16.8 & 17.0 & 17.4 & 17.9 \\
\hline Private & 9.2 & 9.5 & 9.7 & 9.7 & 9.8 & 10.0 & 10.1 & 10.3 & 10.5 \\
\hline Public & 7.9 & 6.3 & 6.5 & 6.4 & 6.6 & 6.8 & 6.9 & 7.2 & 7.4 \\
\hline National Savings & 12.2 & 6.9 & 6.5 & 7.3 & 8.5 & 9.6 & 10.6 & 11.7 & 12.9 \\
\hline Private & 9.2 & 4.2 & 3.8 & 3.4 & 3.9 & 4.2 & 4.4 & 4.8 & 6.2 \\
\hline Public & 2.9 & 2.7 & 2.8 & 4.0 & 4.6 & 5.3 & 6.2 & 6.9 & 6.7 \\
\hline Saving-Investment balance & -4.9 & -8.9 & -9.7 & -8.7 & -7.9 & -7.2 & -6.4 & -5.7 & -5.0 \\
\hline Current account balance & -5.6 & -9.5 & -9.7 & -8.7 & -7.9 & -7.2 & -6.4 & -5.7 & -5.0 \\
\hline Labor market & \multicolumn{9}{|c|}{ (In percent) } \\
\hline Unemployment rate (ILO definition) ${ }^{1}$ & 27.2 & 27.6 & 28.0 & 27.0 & $\ldots$ & $\ldots$ & $\ldots$ & $\ldots$ & $\ldots$ \\
\hline $\begin{array}{l}\text { Source: } \mathrm{BiH}, \mathrm{FBiH} \text { and RS Statistical Agen } \\
\text { Notes: Nominal and real GDP series are } \\
{ }^{1} \text { Based on the } \mathrm{BiH} \text { Labor Survey. The une } \\
\text { is significantly higher. }\end{array}$ & $\begin{array}{l}\text { staff e } \\
\text { produc } \\
\text { te bas }\end{array}$ & $\begin{array}{l}\text { ates. } \\
\text { appro } \\
\text { n the }\end{array}$ & er of $u$ & ed $\mathrm{p}$ & regi & in $L$ & oym & fices & \\
\hline
\end{tabular}




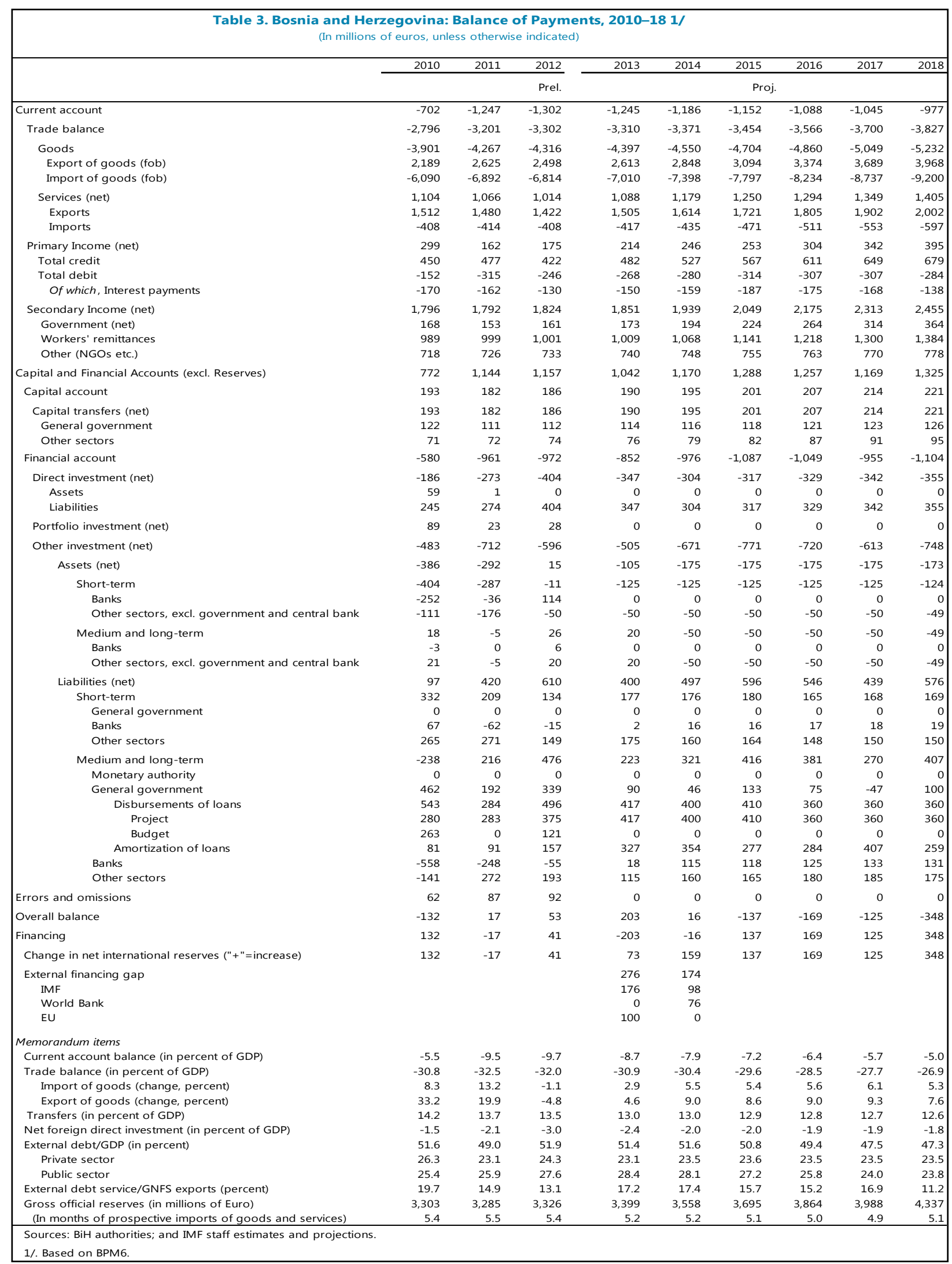

CInternational Monetary Fund. Not for Redistribution 


\begin{tabular}{|c|c|c|c|c|c|c|c|c|c|c|c|}
\hline \multicolumn{12}{|c|}{$\begin{array}{l}\text { Table 4. Bosnia and Herzegovina: General Government Statement of Operations, 2010-18 } \\
\text { (Percent of GDP) }\end{array}$} \\
\hline & \multirow[t]{2}{*}{2010} & \multicolumn{3}{|c|}{2012} & \multicolumn{2}{|c|}{2013} & \multirow[t]{2}{*}{2014} & \multirow[t]{2}{*}{2015} & \multirow[t]{2}{*}{2016} & \multirow[t]{2}{*}{2017} & 2018 \\
\hline & & & $\mathrm{EBS} / 12 / 120$ & Proj. & EBS/12/161 & Proj. & & & & & \\
\hline \begin{tabular}{|l|} 
Revenue \\
\end{tabular} & 46.4 & 46.1 & 46.5 & 45.7 & 46.3 & 44.5 & 44.8 & 44.9 & 45.0 & 45.2 & 45.3 \\
\hline Taxes & 23.0 & 23.1 & 22.9 & 22.6 & 22.7 & 21.6 & 21.7 & 21.8 & 21.8 & 21.8 & 21.8 \\
\hline Direct taxes & 3.6 & 3.5 & 3.6 & 3.5 & 3.6 & 3.4 & 3.4 & 3.4 & 3.4 & 3.4 & 3.4 \\
\hline Indirect taxes & 19.4 & 19.5 & 19.3 & 19.1 & 19.0 & 18.2 & 18.3 & 18.3 & 18.3 & 18.3 & 18.3 \\
\hline Other taxes & 0.0 & 0.1 & 0.0 & 0.1 & 0.1 & 0.1 & 0.0 & 0.0 & 0.0 & 0.0 & 0.0 \\
\hline Social security contributions & 15.4 & 15.8 & 15.7 & 15.4 & 15.4 & 14.9 & 15.3 & 15.3 & 15.3 & 15.3 & 15.3 \\
\hline Grants & 2.4 & 2.1 & 2.1 & 2.2 & 2.2 & 2.1 & 2.1 & 2.2 & 2.3 & 2.5 & 2.6 \\
\hline Other revenue & 5.6 & 5.1 & 5.8 & 5.5 & 6.1 & 6.0 & 5.7 & 5.7 & 5.7 & 5.7 & 5.7 \\
\hline Expenditure & 50.5 & 49.0 & 49.5 & 48.2 & 48.4 & 46.5 & 46.0 & 45.6 & 44.9 & 44.7 & 44.0 \\
\hline Expense & 42.6 & 42.7 & 43.1 & 41.7 & 41.8 & 40.1 & 39.4 & 38.8 & 38.1 & 37.6 & 36.6 \\
\hline Compensation of employees & 12.8 & 13.0 & 13.1 & 12.7 & 12.4 & 11.9 & 11.5 & 11.2 & 10.9 & 10.7 & 10.4 \\
\hline Use of goods and services & 10.1 & 10.6 & 10.6 & 10.3 & 10.6 & 10.3 & 10.2 & 10.2 & 10.2 & 10.1 & 10.1 \\
\hline Social benefits & 14.9 & 14.6 & 14.6 & 14.3 & 14.4 & 13.8 & 13.4 & 13.1 & 12.8 & 12.7 & 12.6 \\
\hline Interest & 0.6 & 0.6 & 0.9 & 0.8 & 0.9 & 0.9 & 1.0 & 0.9 & 0.9 & 0.8 & 0.4 \\
\hline Subsidies & 1.7 & 1.7 & 1.6 & 1.5 & 1.5 & 1.4 & 1.4 & 1.3 & 1.3 & 1.3 & 1.2 \\
\hline Other expense & 2.6 & 2.1 & 2.3 & 2.2 & 2.0 & 1.9 & 2.0 & 2.0 & 2.0 & 1.9 & 1.9 \\
\hline Net acquisition of nonfinancial assets & 7.9 & 6.3 & 6.4 & 6.5 & 6.6 & 6.4 & 6.6 & 6.8 & 6.9 & 7.2 & 7.4 \\
\hline Acquisition of nonfinancial assets & 7.9 & 6.4 & 6.7 & 6.7 & 7.1 & 6.8 & 6.7 & 6.9 & 7.0 & 7.3 & 7.5 \\
\hline Foreign financed capital spending & 4.2 & 3.7 & 4.1 & 3.9 & 4.1 & 4.1 & 4.0 & 4.0 & 4.0 & 4.1 & 4.1 \\
\hline Domestically financed capital spending & 3.7 & 2.7 & 2.6 & 2.8 & 3.0 & 2.8 & 2.8 & 2.9 & 3.0 & 3.2 & 3.5 \\
\hline Disposal of nonfinancial assets & 0.0 & 0.1 & 0.3 & 0.2 & 0.5 & 0.5 & 0.1 & 0.1 & 0.1 & 0.1 & 0.1 \\
\hline Gross / Net Operating Balance (revenue minus expense) & 3.7 & 3.4 & 3.4 & 4.0 & 4.6 & 4.4 & 5.4 & 6.1 & 7.0 & 7.6 & 8.8 \\
\hline Net lending/borrowing (revenue minus expenditure) & -4.2 & -2.9 & -3.0 & -2.5 & -2.0 & -2.0 & -1.2 & -0.7 & 0.1 & 0.4 & 1.3 \\
\hline Net acquisition of financial assets & 0.1 & -1.0 & -0.1 & 0.2 & -0.5 & -0.2 & -0.1 & 0.4 & 0.6 & 0.4 & 1.6 \\
\hline Domestic assets & 0.1 & -0.5 & -0.1 & 0.2 & -0.4 & -0.2 & -0.1 & 0.4 & 0.6 & 0.4 & 1.6 \\
\hline Currency and deposits & 0.0 & -1.1 & -0.9 & -0.4 & -1.2 & -0.9 & -0.1 & 0.6 & 0.8 & 0.6 & 1.6 \\
\hline Debt securities & 0.0 & 0.0 & 0.0 & 0.0 & 0.0 & 0.0 & 0.0 & 0.0 & 0.0 & 0.0 & 0.0 \\
\hline Loans & 0.3 & 0.2 & 0.8 & 0.4 & 0.6 & 0.6 & 0.0 & -0.1 & -0.1 & -0.2 & -0.1 \\
\hline Equity and investment fund shares & -0.2 & 0.3 & 0.0 & 0.2 & 0.1 & 0.1 & 0.0 & 0.0 & 0.0 & 0.0 & 0.0 \\
\hline Insurance, pensions, and standardized guarantee schemes & 0.0 & 0.0 & 0.0 & 0.0 & 0.0 & 0.0 & 0.0 & 0.0 & 0.0 & 0.0 & 0.0 \\
\hline Financial derivatives and employee stock options & 0.0 & 0.0 & 0.0 & 0.0 & 0.0 & 0.0 & 0.0 & 0.0 & 0.0 & 0.0 & 0.0 \\
\hline Other accounts receivable & 0.0 & 0.0 & 0.0 & 0.0 & 0.0 & 0.0 & 0.0 & 0.0 & 0.0 & 0.0 & 0.0 \\
\hline Foreign assets & 0.0 & -0.5 & 0.0 & 0.0 & -0.1 & 0.0 & 0.0 & 0.0 & 0.0 & 0.0 & 0.0 \\
\hline Net incurrence of liabilities & 4.4 & 1.9 & 1.7 & 2.0 & -0.2 & -0.2 & 0.0 & 1.1 & 0.6 & 0.0 & 0.2 \\
\hline Domestic liabilities & 1.4 & 0.7 & -0.7 & 0.5 & -0.8 & -0.8 & -0.4 & 0.2 & -0.1 & 0.0 & -0.7 \\
\hline Currency and deposits & 0.0 & 0.0 & 0.0 & 0.0 & 0.0 & 0.0 & 0.0 & 0.0 & 0.0 & 0.0 & 0.0 \\
\hline Debt securities & 0.0 & 1.0 & 0.3 & 0.3 & -0.1 & -0.1 & 0.1 & 0.8 & 0.6 & 0.2 & -0.3 \\
\hline Issuance & 0.0 & 1.2 & 1.4 & 1.4 & 0.7 & 0.7 & 0.6 & 1.6 & 0.8 & 0.4 & 0.2 \\
\hline Amortization & 0.0 & 0.2 & -1.1 & -1.1 & 0.2 & 0.2 & -0.1 & -0.3 & 0.2 & 0.1 & 0.5 \\
\hline Government obligations under the Law on Internal Debt, & & & & & & & & & & & \\
\hline issued guarantees, and other obligations from previous years & -0.6 & -1.0 & -1.1 & -0.9 & -1.0 & -1.0 & -0.8 & -0.9 & -0.8 & -0.4 & -0.2 \\
\hline Loans & 2.2 & 0.5 & 0.6 & 0.8 & 0.4 & 0.6 & 0.4 & 0.3 & 0.0 & 0.3 & -0.2 \\
\hline Equity and investment fund shares & 0.0 & 0.0 & 0.0 & 0.0 & 0.0 & 0.0 & 0.0 & 0.0 & 0.0 & 0.0 & 0.0 \\
\hline Insurance, pensions, and standardized guarantee schemes & 0.0 & 0.0 & 0.0 & 0.0 & 0.0 & 0.0 & 0.0 & 0.0 & 0.0 & 0.0 & 0.0 \\
\hline Financial derivatives and employee stock options & 0.0 & 0.0 & 0.0 & 0.0 & 0.0 & 0.0 & 0.0 & 0.0 & 0.0 & 0.0 & 0.0 \\
\hline Other accounts payable & -0.3 & 0.2 & -0.5 & 0.2 & -0.1 & -0.4 & 0.0 & 0.0 & 0.0 & 0.0 & 0.0 \\
\hline Foreign liabilities & 3.0 & 1.2 & 2.4 & 1.5 & 0.6 & 0.6 & 0.3 & 0.9 & 0.7 & 0.0 & 1.0 \\
\hline Currency and deposits & 0.0 & 0.0 & 0.0 & 0.0 & 0.0 & 0.0 & 0.0 & 0.0 & 0.0 & 0.0 & 0.0 \\
\hline Debt securities & 0.0 & 0.0 & 0.0 & 0.0 & 0.0 & 0.0 & 0.0 & 0.0 & 0.0 & 0.0 & 0.0 \\
\hline Loans & 3.0 & 1.2 & 2.4 & 1.5 & 0.6 & 0.6 & 0.3 & 0.9 & 0.7 & 0.0 & 1.0 \\
\hline Drawings & 3.9 & 2.1 & 3.6 & 2.7 & 3.0 & 2.9 & 2.7 & 2.6 & 2.4 & 2.2 & 2.1 \\
\hline Amortization & 0.9 & 0.9 & 1.2 & 1.2 & 2.4 & 2.3 & 2.4 & 1.7 & 1.7 & 2.2 & 1.1 \\
\hline Equity and investment fund shares & 0.0 & 0.0 & 0.0 & 0.0 & 0.0 & 0.0 & 0.0 & 0.0 & 0.0 & 0.0 & 0.0 \\
\hline Insurance, pensions, and standardized guarantee schemes & 0.0 & 0.0 & 0.0 & 0.0 & 0.0 & 0.0 & 0.0 & 0.0 & 0.0 & 0.0 & 0.0 \\
\hline Financial derivatives and employee stock options & 0.0 & 0.0 & 0.0 & 0.0 & 0.0 & 0.0 & 0.0 & 0.0 & 0.0 & 0.0 & 0.0 \\
\hline Other accounts payable & 0.0 & 0.0 & 0.0 & 0.0 & 0.0 & 0.0 & 0.0 & 0.0 & 0.0 & 0.0 & 0.0 \\
\hline Financing gap & 0.0 & 0.0 & 1.3 & 0.9 & 1.7 & 1.9 & 1.2 & 0.0 & 0.0 & 0.0 & 0.0 \\
\hline Identified financing & 0.0 & 0.0 & 1.3 & 0.9 & 1.7 & 1.9 & 1.2 & 0.0 & 0.0 & 0.0 & 0.0 \\
\hline IMF & 0.0 & 0.0 & 0.9 & 0.9 & 1.4 & 1.2 & 0.7 & 0.0 & 0.0 & 0.0 & 0.0 \\
\hline WB & 0.0 & 0.0 & 0.0 & 0.0 & 0.0 & 0.0 & 0.5 & 0.0 & 0.0 & 0.0 & 0.0 \\
\hline EU & 0.0 & 0.0 & 0.4 & 0.0 & 0.4 & 0.7 & 0.0 & 0.0 & 0.0 & 0.0 & 0.0 \\
\hline Other & 0.0 & 0.0 & 0.0 & 0.0 & 0.0 & 0.0 & 0.0 & 0.0 & 0.0 & 0.0 & 0.0 \\
\hline Undentified financing & 0.0 & 0.0 & 0.0 & 0.0 & 0.0 & 0.0 & 0.0 & 0.0 & 0.0 & 0.0 & 0.0 \\
\hline Statistical discrepancy & -0.2 & -0.1 & 0.0 & -0.2 & 0.0 & 0.0 & 0.0 & 0.0 & 0.0 & 0.0 & 0.0 \\
\hline Memorandum items & & & & & & & & & & & \\
\hline Indirect revenues & 19.4 & 19.5 & 19.3 & 19.1 & 19.0 & 18.2 & 18.3 & 18.3 & 18.3 & 18.3 & 18.3 \\
\hline Net lending excluding externally-financed operations & -2.3 & -1.2 & -0.9 & -0.7 & -0.1 & 0.1 & 0.7 & 1.2 & 1.8 & 2.1 & 2.9 \\
\hline Structural balance (\% of potential GDP) & -4.2 & -2.5 & -1.7 & -0.8 & -0.2 & -0.2 & 0.8 & 0.7 & $\ldots$ & $\ldots$ & $\ldots$ \\
\hline
\end{tabular}




\begin{tabular}{|c|c|c|c|c|c|c|c|c|c|c|c|c|c|}
\hline \multicolumn{14}{|c|}{$\begin{array}{l}\text { Table 5. Bosnia and Herzegovina: General Government Statement of Operations, 2010-14 } \\
\text { (KM million) }\end{array}$} \\
\hline & \multirow[t]{3}{*}{2010} & \multirow[t]{3}{*}{2011} & \multicolumn{2}{|c|}{2012} & \multirow{2}{*}{\multicolumn{2}{|c|}{ Mar. }} & \multicolumn{4}{|c|}{2013} & \multirow{2}{*}{\multicolumn{2}{|c|}{ Dec. }} & \multirow[t]{3}{*}{2014} \\
\hline & & & \multicolumn{2}{|c|}{ Dec. } & & & \multicolumn{2}{|c|}{ Jun. } & \multicolumn{2}{|l|}{ Sep. } & & & \\
\hline & & & $\mathrm{EBS} / 12 / 120$ & Proj. & $\mathrm{EBS} / 12 / 161$ & Proj. & EBS/12/161 & Proj. & $\mathrm{EBS} / 12 / 161$ & Proj. & EBS/12/161 & Proj. & \\
\hline Revenue & 11486.4 & 11834.4 & 12080.1 & 12043.6 & 2766.5 & 2758.5 & 5884.4 & 5878.3 & 9040.4 & 9002.3 & 12413.9 & 12396.5 & 13100.2 \\
\hline Taxes & 5693.1 & 5929.1 & 5958.8 & 5959.6 & 1370.1 & 1361.8 & 2892.4 & 2875.0 & 4486.3 & 4436.7 & 6069.8 & 6026.7 & 6353.2 \\
\hline Direct taxes & 890.2 & 907.2 & 944.5 & 923.4 & 240.8 & 240.9 & 488.1 & 487.7 & 678.8 & 678.1 & 954.5 & 947.7 & 990.3 \\
\hline Indirect taxes & 4802.9 & 5004.6 & 5002.1 & 5022.9 & 1127.4 & 1119.2 & 2401.0 & 2384.4 & 3802.5 & 3754.2 & 5100.6 & 5064.5 & 5349.2 \\
\hline Other taxes & 0.0 & 17.3 & 12.3 & 13.3 & 1.9 & 1.6 & 3.3 & 2.9 & 5.0 & 4.3 & 14.7 & 14.5 & 13.7 \\
\hline Social security contributions & 3804.0 & 4046.3 & 4080.5 & 4061.8 & 948.7 & 942.0 & 2015.8 & 2001.9 & 3006.4 & 2985.2 & 4134.2 & 4135.3 & 4464.5 \\
\hline Grants & 593.1 & 539.7 & 539.1 & 577.6 & 156.1 & 155.9 & 324.6 & 324.6 & 498.6 & 496.8 & 576.8 & 576.6 & 622.6 \\
\hline Other revenue & 1396.2 & 1319.4 & 1501.7 & 1444.7 & 291.6 & 298.8 & 651.5 & 676.8 & 1049.1 & 1083.6 & 1633.0 & 1657.8 & 1660.0 \\
\hline Expenditure & 12515.7 & 12566.5 & 12861.2 & 12708.6 & 2893.9 & 2887.8 & 6059.8 & 6058.3 & 9386.6 & 9358.5 & 12961.1 & 12946.4 & 13456.6 \\
\hline Expense & 10563.9 & 10954.6 & 11189.7 & 10990.6 & 2589.3 & 2584.6 & 5285.7 & 5293.5 & 8050.4 & 8047.7 & 11188.7 & 11170.7 & 11523.4 \\
\hline Compensation of employees & 3165.6 & 3337.3 & 3397.3 & 3345.9 & 815.1 & 817.2 & 1614.4 & 1618.7 & 2409.9 & 2416.6 & 3311.6 & 3310.7 & 3358.5 \\
\hline Use of goods and services & 2498.5 & 2711.4 & 2754.6 & 2713.7 & 658.8 & 659.0 & 1348.3 & 1350.6 & 2036.6 & 2042.2 & 2833.5 & 2861.6 & 2993.8 \\
\hline Social benefits & 3679.8 & 3749.9 & 3792.2 & 3759.2 & 915.9 & 915.3 & 1829.5 & 1838.6 & 2820.4 & 2823.2 & 3854.1 & 3841.2 & 3908.8 \\
\hline Interest & 150.0 & 164.7 & 225.9 & 199.0 & 42.6 & 47.1 & 109.7 & 119.9 & 152.9 & 166.7 & 245.1 & 240.5 & 283.1 \\
\hline Subsidies & 426.1 & 440.7 & 423.0 & 390.9 & 94.7 & 86.5 & 203.7 & 190.9 & 312.2 & 288.2 & 407.7 & 386.8 & 399.6 \\
\hline Grants & 0.0 & 10.2 & 11.6 & 18.1 & 2.0 & 2.0 & 4.0 & 4.0 & 7.0 & 7.0 & 12.0 & 19.1 & 20.0 \\
\hline Other expense & 643.9 & 550.6 & 596.7 & 581.9 & 62.2 & 59.6 & 180.1 & 174.8 & 318.4 & 310.8 & 536.7 & 529.9 & 579.5 \\
\hline Net acquisition of nonfinancial assets & 1951.8 & 1612.0 & 1671.6 & 1717.9 & 304.6 & 303.2 & 774.1 & 764.8 & 1336.2 & 1310.8 & 1772.4 & 1775.7 & 1933.1 \\
\hline Acquisition of nonfinancial assets & 1951.8 & 1643.0 & 1742.7 & 1758.7 & 312.3 & 317.9 & 790.0 & 785.4 & 1360.0 & 1345.8 & 1907.5 & 1903.8 & 1966.0 \\
\hline Foreign financed capital spending & 1030.8 & 937.6 & 1057.4 & 1018.0 & 231.6 & 237.9 & 469.3 & 481.0 & 738.4 & 758.8 & 1091.5 & 1133.8 & 1156.2 \\
\hline Domestically financed capital spending & 921.0 & 705.4 & 685.2 & 740.7 & 80.7 & 80.0 & 320.7 & 304.4 & 621.6 & 587.0 & 816.1 & 770.0 & 809.8 \\
\hline Disposal of nonfinancial assets & 0.0 & 31.1 & 71.1 & 40.8 & 7.7 & 14.7 & 15.9 & 20.6 & 23.8 & 35.0 & 135.1 & 128.1 & 32.9 \\
\hline Gross / Net Operating Balance (revenue minus expense) & 922.6 & 879.9 & 890.5 & 1053.0 & 177.1 & 173.9 & 598.7 & 584.8 & 990.0 & 954.5 & 1225.2 & 1225.8 & 1576.8 \\
\hline Net lending/borrowing (revenue minus expenditure) & -1029.2 & -732.1 & -781.1 & -664.9 & -127.5 & -129.3 & -175.4 & -180.0 & -346.2 & -356.3 & -547.2 & -549.9 & -356.3 \\
\hline Net acquisition of financial assets & 29.2 & -267.0 & -13.5 & 43.2 & 15.6 & -15.6 & -21.0 & -70.5 & -95.9 & -188.8 & -126.5 & -67.2 & -28.9 \\
\hline Domestic assets & 29.2 & -132.0 & -13.5 & 43.2 & 30.9 & -10.4 & -5.2 & -65.8 & -80.1 & -185.1 & -109.4 & -59.9 & -17.0 \\
\hline Currency and deposits & 0.0 & -276.2 & -227.6 & -109.2 & -37.1 & -86.2 & -118.1 & -155.9 & -211.0 & -297.5 & -310.7 & -253.9 & -16.1 \\
\hline Debt securities & 0.0 & 0.4 & 0.0 & 0.0 & 0.0 & 0.0 & 0.0 & 0.0 & 0.0 & 0.0 & 0.0 & 0.0 & 0.0 \\
\hline Loans & 77.7 & 63.3 & 201.3 & 111.4 & 63.2 & 82.7 & 90.2 & 80.2 & 101.3 & 104.8 & 173.6 & 180.1 & 7.2 \\
\hline Equity and investment fund shares & -48.5 & 71.0 & 12.7 & 41.9 & 4.9 & 2.8 & 22.7 & 22.1 & 29.6 & 22.1 & 27.7 & 21.7 & 0.1 \\
\hline Other accounts receivable & 0.0 & 9.6 & 0.0 & -0.9 & 0.0 & -9.7 & 0.0 & -12.2 & 0.0 & -14.6 & 0.0 & -7.7 & -8.1 \\
\hline Foreign assets & 0.0 & -135.0 & 0.0 & 0.0 & -15.3 & -5.2 & -15.8 & -4.7 & -15.8 & -3.7 & -17.1 & -7.3 & -11.9 \\
\hline Net incurrence of liabilities & 1096.7 & 484.6 & 432.9 & 527.8 & 62.3 & -60.9 & -7.0 & -141.6 & -12.1 & -179.6 & -40.3 & -58.0 & -13.5 \\
\hline Domestic liabilities & 347.7 & 176.2 & -181.7 & 124.8 & 20.8 & -104.6 & 12.7 & -122.9 & 4.9 & -164.1 & -208.6 & -225.7 & -111.2 \\
\hline Debt securities & 0.0 & 256.2 & 69.6 & 87.3 & 4.9 & -4.7 & 4.0 & -9.4 & -13.0 & -33.2 & -16.7 & -16.7 & 20.1 \\
\hline Amortization & -140.5 & -261.0 & -282.5 & -236.7 & -76.0 & -81.1 & -88.7 & -93.4 & -217.7 & -240.3 & -267.7 & -267.7 & -232.0 \\
\hline Loans & 556.2 & 124.6 & 160.8 & 210.2 & -6.5 & -7.6 & 25.6 & 30.7 & 17.2 & 14.5 & 103.5 & 175.7 & 108.8 \\
\hline Other accounts payable & -68.0 & 56.3 & -129.6 & 64.1 & 98.4 & -11.1 & 71.9 & -50.9 & 218.3 & 94.9 & -27.6 & -116.9 & -8.2 \\
\hline Foreign liabilities & 749.0 & 308.5 & 614.6 & 403.0 & 41.6 & 43.7 & -19.7 & -18.7 & -16.9 & -15.4 & 168.3 & 167.7 & 97.8 \\
\hline Debt securities & 0.0 & 0.0 & 0.0 & 0.0 & 0.0 & 0.0 & 0.0 & 0.0 & 0.0 & 0.0 & 0.0 & 0.0 & 0.0 \\
\hline Loans & 749.0 & 310.7 & 613.2 & 403.0 & 41.6 & 43.7 & -19.7 & -18.7 & -16.9 & -15.4 & 168.3 & 167.7 & 97.8 \\
\hline Drawings & 963.0 & 550.5 & 932.1 & 715.5 & 138.6 & 138.6 & 270.9 & 270.9 & 407.9 & 407.9 & 808.9 & 808.9 & 787.1 \\
\hline Amortization & 214.0 & 239.8 & 318.8 & 312.4 & 97.1 & 94.9 & 290.6 & 289.6 & 424.8 & 423.3 & 640.6 & 641.2 & 689.3 \\
\hline Other accounts payable & 0.0 & -2.2 & 1.4 & 0.0 & 0.0 & 0.0 & 0.0 & 0.0 & 0.0 & 0.0 & 0.0 & 0.0 & 0.0 \\
\hline Financing gap & 0.0 & 0.0 & 334.7 & 236.4 & 80.7 & 174.5 & 161.5 & 251.1 & 262.4 & 347.0 & 461.0 & 540.6 & 340.9 \\
\hline Identified financing & 0.0 & 0.0 & 334.7 & 236.4 & 80.7 & 174.5 & 161.4 & 251.2 & 262.3 & 347.0 & 461.0 & 540.6 & 340.9 \\
\hline IMF & 0.0 & 0.0 & 236.9 & 236.4 & 80.7 & 76.7 & 161.4 & 153.4 & 262.3 & 249.2 & 363.2 & 345.1 & 192.5 \\
\hline WB & 0.0 & 0.0 & 0.0 & 0.0 & 0.0 & 0.0 & 0.0 & 0.0 & 0.0 & 0.0 & 0.0 & 0.0 & 148.5 \\
\hline EU & 0.0 & 0.0 & 97.8 & 0.0 & 0.0 & 97.8 & 0.0 & 97.8 & 0.0 & 97.8 & 97.8 & 195.6 & 0.0 \\
\hline Other & 0.0 & 0.0 & 0.0 & 0.0 & 0.0 & 0.0 & 0.0 & 0.0 & 0.0 & 0.0 & 0.0 & 0.0 & 0.0 \\
\hline Undentified financing & 0.0 & 0.0 & 0.0 & 0.0 & 0.0 & 0.0 & 0.0 & 0.0 & 0.0 & 0.0 & 0.0 & 0.0 & 0.0 \\
\hline Statistical discrepancy & -38.2 & -19.6 & 0.0 & -56.1 & 0.0 & 0.0 & 0.0 & 0.0 & 0.0 & 0.0 & 0.0 & 0.0 & 0.0 \\
\hline \multicolumn{14}{|l|}{ Memorandum items } \\
\hline Indirect revenues & 4802.9 & 5004.6 & 5002.1 & 5022.9 & 1127.4 & 1119.2 & 2401.0 & 2384.4 & 3802.5 & 3754.2 & 5100.6 & 5064.5 & 5349.2 \\
\hline Net lending excluding externally-financed operations & -565.8 & -314.1 & -237.6 & -192.6 & -50.9 & -46.4 & -24.6 & -17.4 & -97.1 & -86.8 & -17.1 & 22.8 & 193.2 \\
\hline
\end{tabular}




\begin{tabular}{|c|c|c|c|c|c|c|c|c|c|c|c|c|c|}
\hline \multicolumn{14}{|c|}{$\begin{array}{l}\text { Table 5a. Institutions of Bosnia and Herzegovina: Statement of Operations, 2010-14 } \\
\qquad \text { (KM million) }\end{array}$} \\
\hline & \multirow[t]{3}{*}{2010} & \multirow[t]{3}{*}{2011} & \multicolumn{2}{|c|}{2012} & \multicolumn{8}{|c|}{2013} & \multirow[t]{3}{*}{2014} \\
\hline & & & \multicolumn{2}{|c|}{ Dec. } & \multicolumn{2}{|c|}{ Mar. } & \multicolumn{2}{|l|}{ Jun. } & \multicolumn{2}{|c|}{ Sep. } & \multicolumn{2}{|c|}{ Dec. } & \\
\hline & & & $\mathrm{EBS} / 12 / 120$ & Prel. & $E B S / 12 / 161$ & Proj. & $\mathrm{EBS} / 12 / 161$ & Proj. & EBS/12/161 & Proj. & EBS/12/161 & Proj. & \\
\hline Revenue & 885.4 & 848.3 & 909.7 & 924.4 & 193.1 & 192.5 & 445.8 & 444.6 & 676.3 & 672.1 & 923.2 & 923.2 & 937.5 \\
\hline Taxes & 689.0 & 689.0 & 750.0 & 750.0 & 167.6 & 167.6 & 367.8 & 367.8 & 558.9 & 558.9 & 750.0 & 750.0 & 750.0 \\
\hline Direct taxes & 0.0 & 0.0 & 0.0 & 0.0 & 0.0 & 0.0 & 0.0 & 0.0 & 0.0 & 0.0 & 0.0 & 0.0 & 0.0 \\
\hline Indirect taxes & 689.0 & 689.0 & 750.0 & 750.0 & 167.6 & 167.6 & 367.8 & 367.8 & 558.9 & 558.9 & 750.0 & 750.0 & 750.0 \\
\hline Other taxes & 0.0 & 0.0 & 0.0 & 0.0 & 0.0 & 0.0 & 0.0 & 0.0 & 0.0 & 0.0 & 0.0 & 0.0 & 0.0 \\
\hline Social security contributions & 0.0 & 0.0 & 0.0 & 0.0 & 0.0 & 0.0 & 0.0 & 0.0 & 0.0 & 0.0 & 0.0 & 0.0 & 0.0 \\
\hline Grants & 22.0 & 17.7 & 15.0 & 21.7 & 0.7 & 0.5 & 5.0 & 5.0 & 5.8 & 4.0 & 7.2 & 7.2 & 7.6 \\
\hline Other revenue & 174.4 & 141.6 & 144.7 & 151.7 & 24.8 & 24.4 & 73.0 & 71.8 & 111.6 & 109.2 & 166.0 & 166.0 & 179.9 \\
\hline Transfers from other general government units & 0.0 & 1.2 & 0.0 & 1.1 & 0.0 & 0.0 & 0.0 & 0.0 & 0.0 & 0.0 & 0.0 & 0.0 & 0.0 \\
\hline Expenditure & 972.7 & 898.7 & 950.0 & 882.1 & 208.4 & 207.4 & 461.5 & 459.5 & 697.6 & 691.5 & 950.0 & 950.0 & 950.0 \\
\hline Expense & 904.5 & 877.3 & 889.7 & 844.5 & 200.1 & 200.4 & 415.0 & 415.4 & 630.5 & 630.9 & 877.9 & 877.9 & 888.7 \\
\hline Compensation of employees & 634.0 & 648.4 & 635.5 & 628.3 & 160.6 & 161.6 & 317.0 & 318.9 & 476.3 & 479.1 & 636.2 & 636.2 & 645.0 \\
\hline Use of goods and services & 204.7 & 179.3 & 179.9 & 162.4 & 35.0 & 34.4 & 80.7 & 79.4 & 128.3 & 126.3 & 193.7 & 193.7 & 194.2 \\
\hline Social benefits & 0.0 & 38.5 & 12.0 & 11.5 & 0.6 & 0.6 & 5.8 & 6.1 & 8.8 & 9.1 & 11.5 & 11.5 & 11.5 \\
\hline Interest & 0.5 & 0.3 & 0.7 & 0.0 & 0.0 & 0.0 & 0.0 & 0.0 & 0.0 & 0.0 & 0.5 & 0.5 & 3.4 \\
\hline Transfers to other general government units & -3.0 & -1.2 & 19.9 & 19.5 & 0.0 & 0.0 & 0.0 & 0.0 & 0.0 & 0.0 & 0.0 & 0.0 & 0.0 \\
\hline Other expense & 68.2 & 12.1 & 41.7 & 22.8 & 3.9 & 3.7 & 11.5 & 11.0 & 17.1 & 16.3 & 35.9 & 35.9 & 34.5 \\
\hline Net acquisition of nonfinancial assets & 68.3 & 21.4 & 60.3 & 37.6 & 8.3 & 7.0 & 46.5 & 44.1 & 67.1 & 60.5 & 72.1 & 72.1 & 61.3 \\
\hline Acquisition of nonfinancial assets & 68.3 & 21.9 & 67.7 & 45.3 & 8.3 & 7.1 & 46.5 & 44.1 & 67.1 & 60.5 & 72.8 & 72.8 & 61.3 \\
\hline Foreign financed capital spending & 0.0 & 3.4 & 2.1 & 2.2 & 0.3 & 0.5 & 0.8 & 1.0 & 1.3 & 1.7 & 1.8 & 1.8 & 0.0 \\
\hline Domestically financed capital spending & 68.3 & 18.5 & 65.6 & 43.0 & 7.9 & 6.6 & 45.7 & 43.1 & 65.8 & 58.9 & 71.0 & 71.0 & 61.3 \\
\hline Disposal of nonfinancial assets & 0.0 & 0.6 & 7.4 & 7.7 & 0.0 & 0.0 & 0.0 & 0.0 & 0.0 & 0.0 & 0.7 & 0.7 & 0.0 \\
\hline Gross / Net Operating Balance (revenue minus expense) & -19.1 & -29.0 & 20.0 & 79.9 & -7.0 & -7.9 & 30.8 & 29.2 & 45.9 & 41.2 & 45.3 & 45.3 & 48.8 \\
\hline Net lending/borrowing (revenue minus expenditure) & -87.3 & -50.4 & -40.3 & 42.3 & -15.3 & -15.0 & -15.7 & -14.9 & -21.2 & -19.4 & -26.8 & -26.8 & -12.5 \\
\hline Net acquisition of financial assets & -17.5 & -83.0 & -25.1 & 8.0 & -15.3 & -5.2 & -15.8 & -4.7 & -15.8 & -3.7 & -17.1 & -7.3 & -12.5 \\
\hline Domestic assets & -17.5 & 52.0 & -25.1 & 8.0 & 0.0 & 0.0 & 0.0 & 0.0 & 0.0 & 0.0 & 0.0 & 0.0 & -0.6 \\
\hline Currency and deposits & 0.0 & 49.0 & -25.1 & 16.0 & 0.0 & 0.0 & 0.0 & 0.0 & 0.0 & 0.0 & 0.0 & 0.0 & -0.6 \\
\hline Debt securities & 0.0 & 0.0 & 0.0 & 0.0 & 0.0 & 0.0 & 0.0 & 0.0 & 0.0 & 0.0 & 0.0 & 0.0 & 0.0 \\
\hline Loans & 0.0 & 0.0 & 0.0 & 0.0 & 0.0 & 0.0 & 0.0 & 0.0 & 0.0 & 0.0 & 0.0 & 0.0 & 0.0 \\
\hline Equity and investment fund shares & -17.5 & -1.0 & 0.0 & 0.0 & 0.0 & 0.0 & 0.0 & 0.0 & 0.0 & 0.0 & 0.0 & 0.0 & 0.0 \\
\hline Other accounts receivable & 0.0 & 4.0 & 0.0 & -8.0 & 0.0 & 0.0 & 0.0 & 0.0 & 0.0 & 0.0 & 0.0 & 0.0 & 0.0 \\
\hline Foreign assets & 0.0 & -135.0 & 0.0 & 0.0 & -15.3 & -5.2 & -15.8 & -4.7 & -15.8 & -3.7 & -17.1 & -7.3 & -11.9 \\
\hline Net incurrence of liabilities & 34.6 & -34.1 & 5.4 & -34.0 & 0.0 & 0.0 & -0.1 & 0.5 & 5.4 & 5.9 & 0.0 & 0.0 & 0.0 \\
\hline Domestic liabilities & 36.7 & -33.0 & 0.0 & -34.0 & 0.0 & 0.0 & -0.1 & 0.5 & 5.4 & 5.9 & 0.0 & 0.0 & 0.0 \\
\hline Debt securities & 0.0 & 0.0 & 0.0 & 0.0 & 0.0 & 0.0 & 0.0 & 0.0 & 0.0 & 0.0 & 0.0 & 0.0 & 0.0 \\
\hline Issuance & 0.0 & 0.0 & 0.0 & 0.0 & 0.0 & 0.0 & 0.0 & 0.0 & 0.0 & 0.0 & 0.0 & 0.0 & 0.0 \\
\hline Amortization & 0.0 & 0.0 & 0.0 & 0.0 & 0.0 & 0.0 & 0.0 & 0.0 & 0.0 & 0.0 & 0.0 & 0.0 & 0.0 \\
\hline Government obligations under the Law on Internal Debt & & & & & & & & & & & & & \\
\hline guarantees, and other obligations from previous years & 0.0 & 0.0 & 0.0 & 0.0 & 0.0 & 0.0 & 0.0 & 0.0 & 0.0 & 0.0 & 0.0 & 0.0 & 0.0 \\
\hline Loans & 43.7 & 0.0 & 0.0 & 0.0 & 0.0 & 0.0 & 0.0 & 0.0 & 0.0 & 0.0 & 0.0 & 0.0 & 0.0 \\
\hline Other accounts payable & -7.0 & -33.0 & 0.0 & -34.0 & 0.0 & 0.0 & -0.1 & 0.5 & 5.4 & 5.9 & 0.0 & 0.0 & 0.0 \\
\hline Foreign liabilities & -2.1 & -1.1 & 5.4 & 0.0 & 0.0 & 0.0 & 0.0 & 0.0 & 0.0 & 0.0 & 0.0 & 0.0 & 0.0 \\
\hline Debt securities & 0.0 & 0.0 & 0.0 & 0.0 & 0.0 & 0.0 & 0.0 & 0.0 & 0.0 & 0.0 & 0.0 & 0.0 & 0.0 \\
\hline Loans & -2.1 & -1.1 & 5.4 & 0.0 & 0.0 & 0.0 & 0.0 & 0.0 & 0.0 & 0.0 & 0.0 & 0.0 & 0.0 \\
\hline Drawings & 0.0 & 0.0 & 5.4 & 0.0 & 0.0 & 0.0 & 0.0 & 0.0 & 0.0 & 0.0 & 0.0 & 0.0 & 0.0 \\
\hline Amortization & 2.1 & 1.1 & 0.0 & 0.0 & 0.0 & 0.0 & 0.0 & 0.0 & 0.0 & 0.0 & 0.0 & 0.0 & 0.0 \\
\hline Other accounts payable & 0.0 & 0.0 & 0.0 & 0.0 & 0.0 & 0.0 & 0.0 & 0.0 & 0.0 & 0.0 & 0.0 & 0.0 & 0.0 \\
\hline Financing gap & 0.0 & 0.0 & 9.8 & 0.0 & 0.0 & 9.8 & 0.0 & 9.7 & 0.0 & 9.8 & 9.8 & 19.6 & 0.0 \\
\hline Identified financing & 0.0 & 0.0 & 9.8 & 0.0 & 0.0 & 9.8 & 0.0 & 9.8 & 0.0 & 9.8 & 9.8 & 19.6 & 0.0 \\
\hline IMF & 0.0 & 0.0 & 0.0 & 0.0 & 0.0 & 0.0 & 0.0 & 0.0 & 0.0 & 0.0 & 0.0 & 0.0 & 0.0 \\
\hline WB & 0.0 & 0.0 & 0.0 & 0.0 & 0.0 & 0.0 & 0.0 & 0.0 & 0.0 & 0.0 & 0.0 & 0.0 & 0.0 \\
\hline EU & 0.0 & 0.0 & 9.8 & 0.0 & 0.0 & 9.8 & 0.0 & 9.8 & 0.0 & 9.8 & 9.8 & 19.6 & 0.0 \\
\hline Other & 0.0 & 0.0 & 0.0 & 0.0 & 0.0 & 0.0 & 0.0 & 0.0 & 0.0 & 0.0 & 0.0 & 0.0 & 0.0 \\
\hline Undentified financing & 0.0 & 0.0 & 0.0 & 0.0 & 0.0 & 0.0 & 0.0 & 0.0 & 0.0 & 0.0 & 0.0 & 0.0 & 0.0 \\
\hline Statistical discrepancy & 35.3 & 1.5 & 0.0 & 0.3 & 0.0 & 0.0 & 0.0 & 0.0 & 0.0 & 0.0 & 0.0 & 0.0 & 0.0 \\
\hline Memorandum items & & & & & & & & & & & & & \\
\hline Indirect revenues & 689.0 & 689.0 & 750.0 & 750.0 & 167.6 & 167.6 & 367.8 & 367.8 & 558.9 & 558.9 & 750.0 & 750.0 & 750.0 \\
\hline Net lending excluding externally-financed operations & -87.3 & -47.0 & -38.2 & 44.5 & -15.0 & -14.5 & -15.0 & -13.9 & -20.0 & -17.7 & -25.0 & -25.0 & -12.5 \\
\hline
\end{tabular}




\begin{tabular}{|c|c|c|c|c|c|c|c|c|c|c|c|c|c|}
\hline \multicolumn{14}{|c|}{$\begin{array}{l}\text { Table 5b. Federation of Bosnia and Herzegovina: General } \\
\text { (KM million) }\end{array}$} \\
\hline & \multirow[t]{3}{*}{2010} & \multirow[t]{3}{*}{2011} & \multicolumn{2}{|c|}{2012} & \multicolumn{8}{|c|}{2013} & \multirow[t]{3}{*}{2014} \\
\hline & & & \multicolumn{2}{|c|}{ Dec. } & \multicolumn{2}{|c|}{ Mar. } & \multicolumn{2}{|c|}{ Jun. } & \multicolumn{2}{|c|}{ Sep. } & \multicolumn{2}{|c|}{ Dec. } & \\
\hline & & & EBS/12/120 & Proj. & EBS/12/161 & Proj. & EBS/12/161 & Proj. & $\mathrm{EBS} / 12 / 161$ & Proj. & EBS/12/161 & Proj. & \\
\hline Revenue & 6918.5 & 6926.5 & 7079.1 & 7057.3 & 1641.2 & 1631.4 & 3453.8 & 3440.6 & 5355.5 & 5317.4 & 7287.5 & 7271.5 & 7725.2 \\
\hline Taxes & 3161.2 & 3177.8 & 3172.5 & 3168.5 & 737.2 & 733.4 & 1541.8 & 1533.3 & 2405.2 & 2377.1 & 3250.5 & 3228.3 & 3427.8 \\
\hline Direct taxes & 529.5 & 468.8 & 495.3 & 478.5 & 133.4 & 134.8 & 263.1 & 265.0 & 365.6 & 367.9 & 507.2 & 507.6 & 527.7 \\
\hline Indirect taxes & 2631.7 & 2700.2 & 2668.8 & 2682.7 & 602.9 & 597.7 & 1277.1 & 1266.7 & 2037.3 & 2007.0 & 2732.3 & 2709.7 & 2888.7 \\
\hline Other taxes & 0.0 & 8.9 & 8.5 & 7.3 & 0.9 & 0.9 & 1.6 & 1.6 & 2.3 & 2.3 & 11.0 & 11.0 & 11.3 \\
\hline Social security contributions & 2615.5 & 2649.0 & 2660.0 & 2680.0 & 630.5 & 622.2 & 1315.9 & 1298.7 & 1996.2 & 1970.1 & 2703.9 & 2697.3 & 2930.6 \\
\hline Foreign grants & 382.0 & 352.3 & 352.7 & 365.9 & 108.7 & 108.7 & 226.1 & 226.1 & 352.5 & 352.5 & 382.4 & 382.4 & 412.8 \\
\hline Other revenue & 759.8 & 747.4 & 872.3 & 842.9 & 164.9 & 167.1 & 370.0 & 382.5 & 601.7 & 617.8 & 950.7 & 963.4 & 954.0 \\
\hline Expenditure & 7279.8 & 7317.5 & 7577.6 & 7542.5 & 1745.1 & 1752.8 & 3590.1 & 3607.8 & 5525.8 & 5558.3 & 7691.9 & 7697.3 & 8019.4 \\
\hline Expense & 6280.8 & 6424.2 & 6602.7 & 6471.5 & 1526.2 & 1534.3 & 3093.6 & 3112.9 & 4700.6 & 4729.8 & 6548.0 & 6551.6 & 6832.5 \\
\hline Compensation of employees & 1621.7 & 1675.5 & 1726.3 & 1685.7 & 415.6 & 417.9 & 810.3 & 815.1 & 1207.0 & 1214.3 & 1696.3 & 1698.7 & 1764.7 \\
\hline Use of goods and services & 1457.5 & 1528.5 & 1547.6 & 1506.5 & 390.8 & 390.0 & 784.9 & 784.5 & 1154.3 & 1155.6 & 1583.0 & 1581.7 & 1657.9 \\
\hline Social benefits & 2421.3 & 2467.4 & 2522.0 & 2514.4 & 609.5 & 613.3 & 1214.1 & 1221.4 & 1874.1 & 1883.4 & 2519.7 & 2532.8 & 2587.0 \\
\hline Interest & 92.1 & 96.6 & 121.8 & 107.8 & 21.5 & 24.2 & 55.6 & 63.1 & 78.6 & 88.8 & 128.2 & 128.2 & 164.0 \\
\hline Subsidies & 261.2 & 250.5 & 280.0 & 254.3 & 50.9 & 50.9 & 119.8 & 119.8 & 175.9 & 175.9 & 241.9 & 241.9 & 247.4 \\
\hline Other expense & 379.7 & 405.7 & 405.1 & 402.8 & 37.9 & 37.9 & 108.9 & 109.1 & 210.7 & 211.8 & 378.7 & 368.3 & 411.4 \\
\hline Net acquisition of nonfinancial assets & 999.0 & 893.3 & 974.9 & 1071.0 & 218.9 & 218.5 & 496.5 & 494.8 & 825.2 & 828.5 & 1144.0 & 1145.7 & 1187.0 \\
\hline Acquisition of nonfinancial assets & 999.0 & 900.8 & 1011.9 & 1082.6 & 220.0 & 219.7 & 500.2 & 498.6 & 831.9 & 835.3 & 1201.2 & 1203.2 & 1198.1 \\
\hline Foreign financed capital spending & 680.2 & 638.5 & 693.3 & 707.5 & 177.6 & 177.6 & 360.3 & 360.3 & 553.0 & 553.0 & 818.3 & 818.3 & 805.8 \\
\hline Domestically financed capital spending & 318.8 & 262.3 & 318.6 & 375.1 & 42.4 & 42.1 & 139.9 & 138.3 & 278.9 & 282.4 & 382.9 & 384.8 & 392.3 \\
\hline Disposal of nonfinancial assets & 0.0 & 7.6 & 37.0 & 11.6 & 1.1 & 1.2 & 3.7 & 3.8 & 6.7 & 6.8 & 57.2 & 57.5 & 11.1 \\
\hline Gross / Net Operating Balance (revenue minus expense) & 637.7 & 489.1 & 476.4 & 585.8 & 115.0 & 97.1 & 360.2 & 327.6 & 654.9 & 587.6 & 739.6 & 719.9 & 892.7 \\
\hline Net lending/borrowing (revenue minus expenditure) & -361.3 & -404.2 & -498.4 & -485.2 & -103.9 & -121.4 & -136.3 & -167.2 & -170.3 & -240.9 & -404.4 & -425.9 & -294.3 \\
\hline Net acquisition of financial assets & -44.2 & -288.4 & -321.9 & -146.6 & -22.3 & -87.9 & -78.4 & -156.7 & -149.3 & -286.7 & -220.3 & -243.1 & -189.0 \\
\hline Domestic assets & -44.2 & -288.4 & -321.9 & -146.6 & -22.3 & -87.9 & -78.4 & -156.7 & -149.3 & -286.7 & -220.3 & -243.1 & -189.0 \\
\hline Currency and deposits & 0.0 & -213.0 & -229.8 & -102.3 & -22.6 & -89.5 & -78.9 & -159.3 & -151.9 & -290.5 & -219.6 & -253.1 & -94.7 \\
\hline Debt securities & 0.0 & 0.0 & 0.0 & 0.0 & 0.0 & 0.0 & 0.0 & 0.0 & 0.0 & 0.0 & 0.0 & 0.0 & 0.0 \\
\hline Loans & -38.4 & -69.2 & -89.1 & -42.7 & -0.1 & 1.5 & -0.2 & 2.6 & -0.3 & 3.9 & 6.4 & 9.9 & -94.3 \\
\hline Equity and investment fund shares & -5.8 & -6.2 & -3.0 & -1.6 & 0.3 & 0.0 & 0.6 & 0.0 & 3.0 & 0.0 & -7.0 & 0.1 & 0.1 \\
\hline Insurance, pensions, and standardized guarantee schemes & 0.0 & -0.1 & 0.0 & 0.0 & 0.0 & 0.0 & 0.0 & 0.0 & 0.0 & 0.0 & 0.0 & 0.0 & 0.0 \\
\hline Financial derivatives and employee stock options & 0.0 & 0.0 & 0.0 & 0.0 & 0.0 & 0.0 & 0.0 & 0.0 & 0.0 & 0.0 & 0.0 & 0.0 & 0.0 \\
\hline Other accounts receivable & 0.0 & 0.0 & 0.0 & 0.0 & 0.0 & 0.0 & 0.0 & 0.0 & 0.0 & 0.0 & 0.0 & 0.0 & 0.0 \\
\hline Foreign assets & 0.0 & 0.0 & 0.0 & 0.0 & 0.0 & 0.0 & 0.0 & 0.0 & 0.0 & 0.0 & 0.0 & 0.0 & 0.0 \\
\hline Net incurrence of liabilities & 374.5 & 199.0 & -17.8 & 186.7 & 27.7 & -76.3 & -49.7 & -150.4 & -154.0 & -270.6 & -116.7 & -164.7 & -122.0 \\
\hline Domestic liabilities & -116.8 & 49.5 & -165.1 & 30.7 & 23.9 & -82.3 & 5.8 & -95.8 & -78.5 & -196.6 & -139.9 & -187.4 & -70.3 \\
\hline Currency and deposits & 0.0 & 0.0 & 0.0 & 0.0 & 0.0 & 0.0 & 0.0 & 0.0 & 0.0 & 0.0 & 0.0 & 0.0 & 0.0 \\
\hline Debt securities & 0.0 & 89.7 & 42.9 & 101.2 & 4.9 & -4.7 & 5.3 & -8.1 & -11.7 & -31.9 & 40.0 & 40.0 & 3.9 \\
\hline Amortization & -77.4 & -95.1 & -134.5 & -115.5 & -36.2 & -42.1 & -37.0 & -42.9 & -146.7 & -171.5 & -175.9 & -175.9 & -146.0 \\
\hline Loans & 21.5 & 6.0 & 56.1 & 28.1 & 4.1 & 2.1 & 35.2 & 32.0 & 38.3 & 34.9 & 23.4 & 11.8 & 71.7 \\
\hline Equity and investment fund shares & 0.0 & 0.0 & 0.0 & 0.0 & 0.0 & 0.0 & 0.0 & 0.0 & 0.0 & 0.0 & 0.0 & 0.0 & 0.0 \\
\hline Insurance, pensions, and standardized guarantee schemes & 0.0 & 0.0 & 0.0 & 0.0 & 0.0 & 0.0 & 0.0 & 0.0 & 0.0 & 0.0 & 0.0 & 0.0 & 0.0 \\
\hline Financial derivatives and employee stock options & 0.0 & 0.0 & 0.0 & 0.0 & 0.0 & 0.0 & 0.0 & 0.0 & 0.0 & 0.0 & 0.0 & 0.0 & 0.0 \\
\hline Other accounts payable & -60.9 & 48.9 & -129.6 & 16.9 & 51.1 & -37.6 & 2.3 & -76.8 & 41.6 & -28.1 & -27.5 & -63.3 & 0.0 \\
\hline Foreign liabilities & 491.3 & 149.5 & 147.3 & 156.0 & 3.8 & 6.0 & -55.5 & -54.5 & -75.4 & -73.9 & 23.3 & 22.7 & -51.7 \\
\hline Currency and deposits & 0.0 & 0.0 & 0.0 & 0.0 & 0.0 & 0.0 & 0.0 & 0.0 & 0.0 & 0.0 & 0.0 & 0.0 & 0.0 \\
\hline Debt securities & 0.0 & 0.0 & 0.0 & 0.0 & 0.0 & 0.0 & 0.0 & 0.0 & 0.0 & 0.0 & 0.0 & 0.0 & 0.0 \\
\hline Loans & 491.3 & 151.7 & 147.3 & 156.0 & 3.8 & 6.0 & -55.5 & -54.5 & -75.4 & -73.9 & 23.3 & 22.7 & -51.7 \\
\hline Drawings & 624.7 & 295.3 & 350.8 & 351.8 & 69.3 & 69.3 & 135.4 & 135.4 & 203.9 & 203.9 & 447.8 & 447.8 & 406.4 \\
\hline Amortization & 133.4 & 143.6 & 203.5 & 195.8 & 65.5 & 63.4 & 191.0 & 190.0 & 279.4 & 277.9 & 424.5 & 425.1 & 458.1 \\
\hline Equity and investment fund shares & 0.0 & 0.0 & 0.0 & 0.0 & 0.0 & 0.0 & 0.0 & 0.0 & 0.0 & 0.0 & 0.0 & 0.0 & 0.0 \\
\hline Insurance, pensions, and standardized guarantee schemes & 0.0 & 0.0 & 0.0 & 0.0 & 0.0 & 0.0 & 0.0 & 0.0 & 0.0 & 0.0 & 0.0 & 0.0 & 0.0 \\
\hline Financial derivatives and employee stock options & 0.0 & 0.0 & 0.0 & 0.0 & 0.0 & 0.0 & 0.0 & 0.0 & 0.0 & 0.0 & 0.0 & 0.0 & 0.0 \\
\hline Other accounts payable & 0.0 & -2.2 & 0.0 & 0.0 & 0.0 & 0.0 & 0.0 & 0.0 & 0.0 & 0.0 & 0.0 & 0.0 & 0.0 \\
\hline Statistical discrepancy / financing gap & -57.4 & -83.2 & 194.3 & 151.9 & 53.8 & 109.8 & 107.6 & 160.9 & 174.9 & 224.8 & 300.8 & 347.4 & 227.3 \\
\hline
\end{tabular}




\begin{tabular}{|c|c|c|c|c|c|c|c|c|c|c|c|c|c|}
\hline \multicolumn{14}{|c|}{$\begin{array}{l}\text { Table 5c. Federation of Bosnia and Herzegovina: Central Government Statement of Operations, 2010-14 } \\
\qquad \text { (KM million) }\end{array}$} \\
\hline & \multirow[t]{3}{*}{2010} & \multirow[t]{3}{*}{2011} & \multicolumn{2}{|c|}{2012} & \multicolumn{8}{|c|}{2013} & \multirow[t]{3}{*}{2014} \\
\hline & & & $\mathrm{De}$ & & $\mathrm{Ma}$ & & Jun & & Sep & & Dec & & \\
\hline & & & :12/120 & Prel. & $12 / 161$ & Proj. & $\mathrm{EBS} / 12 / 161$ & Proj. & EBS/12/161 & Proj. & EBS/12/161 & Proj. & \\
\hline Revenue & 1810.8 & 1672.3 & 1804.8 & 1817.3 & 434.5 & 431.2 & 982.3 & 984.7 & 1532.5 & 1533.3 & 2042.9 & 2031.7 & 2119.0 \\
\hline Taxes & 1218.2 & 1137.5 & 1190.8 & 1171.2 & 290.6 & 289.0 & 637.1 & 635.1 & 978.6 & 970.2 & 1342.7 & 1335.3 & 1428.5 \\
\hline Direct taxes & 95.4 & 46.6 & 64.9 & 47.1 & 24.4 & 25.6 & 34.2 & 35.9 & 40.4 & 42.4 & 51.7 & 51.7 & 54.6 \\
\hline Indirect taxes & 1122.8 & 1090.8 & 1125.9 & 1124.1 & 266.2 & 263.4 & 602.9 & 599.2 & 938.3 & 927.8 & 1291.1 & 1283.6 & 1373.9 \\
\hline Other taxes & 0.0 & 0.2 & 0.0 & 0.0 & 0.0 & 0.0 & 0.0 & 0.0 & 0.0 & 0.0 & 0.0 & 0.0 & 0.0 \\
\hline Social security contributions & 0.0 & 0.0 & 0.0 & 0.0 & 0.0 & 0.0 & 0.0 & 0.0 & 0.0 & 0.0 & 0.0 & 0.0 & 0.0 \\
\hline Grants & 378.2 & 343.5 & 342.5 & 355.7 & 108.3 & 108.3 & 224.9 & 224.9 & 349.0 & 349.0 & 374.1 & 374.1 & 404.4 \\
\hline Other revenue & 214.4 & 191.3 & 271.5 & 290.3 & 35.7 & 33.9 & 120.3 & 124.7 & 204.8 & 214.1 & 326.2 & 322.4 & 286.1 \\
\hline Expenditure & 2054.9 & 1955.1 & 2029.4 & 1934.2 & 493.1 & 489.0 & 1004.5 & 1026.1 & 1537.8 & 1530.5 & 2204.1 & 2191.8 & 2221.0 \\
\hline Expense & 1339.6 & 1372.0 & 1399.6 & 1377.3 & 319.6 & 316.4 & 669.5 & 674.7 & 1018.5 & 1020.8 & 1436.2 & 1427.7 & 1456.9 \\
\hline Compensation of employees & 220.0 & 239.7 & 232.5 & 225.9 & 57.6 & 59.3 & 114.4 & 117.7 & 170.6 & 175.6 & 237.8 & 237.8 & 242.1 \\
\hline Use of goods and services & 85.7 & 67.0 & 63.0 & 66.4 & 35.0 & 34.0 & 45.0 & 44.0 & 58.9 & 54.4 & 93.1 & 90.6 & 66.0 \\
\hline Social benefits & 480.5 & 468.7 & 460.7 & 460.9 & 107.1 & 107.8 & 216.0 & 216.9 & 350.4 & 350.1 & 456.1 & 456.1 & 457.5 \\
\hline Interest & 81.4 & 84.7 & 105.8 & 91.8 & 19.1 & 21.7 & 49.7 & 57.2 & 69.5 & 79.7 & 110.1 & 110.1 & 145.3 \\
\hline Subsidies & 131.9 & 115.5 & 127.5 & 128.6 & 26.2 & 26.2 & 70.0 & 70.0 & 100.0 & 100.0 & 130.5 & 130.5 & 130.5 \\
\hline Transfers to other general government units & 276.8 & 327.6 & 272.3 & 308.3 & 62.4 & 55.2 & 139.7 & 134.2 & 192.9 & 184.9 & 272.1 & 276.6 & 285.9 \\
\hline Other expense & 63.2 & 69.0 & 137.8 & 95.4 & 12.3 & 12.3 & 34.8 & 34.7 & 76.2 & 76.1 & 136.5 & 126.0 & 129.5 \\
\hline Net acquisition of nonfinancial assets & 715.3 & 583.1 & 629.9 & 556.9 & 173.5 & 172.6 & 335.0 & 351.3 & 519.2 & 509.6 & 767.9 & 764.1 & 764.2 \\
\hline Acquisition of nonfinancial assets & 715.3 & 583.1 & 629.9 & 558.5 & 173.5 & 172.6 & 335.0 & 351.3 & 519.2 & 509.6 & 767.9 & 764.1 & 764.2 \\
\hline Foreign financed capital spending & 632.2 & 569.4 & 611.1 & 547.5 & 166.8 & 166.8 & 307.1 & 327.1 & 474.3 & 467.1 & 714.2 & 714.2 & 711.8 \\
\hline Domestically financed capital spending & 83.1 & 13.7 & 18.8 & 11.0 & 6.7 & 5.7 & 27.9 & 24.3 & 44.9 & 42.5 & 53.7 & 49.9 & 52.4 \\
\hline Disposal of nonfinancial assets & 0.0 & 0.0 & 0.0 & 1.6 & 0.0 & 0.0 & 0.0 & 0.0 & 0.0 & 0.0 & 0.0 & 0.0 & 0.0 \\
\hline Gross / Net Operating Balance (revenue minus expense) & 471.2 & 300.3 & 405.2 & 440.0 & 115.0 & 114.8 & 312.8 & 310.0 & 513.9 & 512.5 & 606.7 & 604.0 & 662.2 \\
\hline Net lending/borrowing (revenue minus expenditure) & -244.1 & -282.8 & -224.6 & -116.9 & -58.6 & -57.8 & -22.2 & -41.3 & -5.3 & 2.9 & -161.2 & -160.1 & -102.0 \\
\hline Net acquisition of financial assets & -26.5 & -238.0 & -52.3 & 48.1 & -20.6 & -21.0 & -41.3 & -41.9 & -59.9 & -62.9 & -109.0 & -72.6 & -146.7 \\
\hline Domestic assets & -26.5 & -238.0 & -52.3 & 48.1 & -20.6 & -21.0 & -41.3 & -41.9 & -59.9 & -62.9 & -109.0 & -72.6 & -146.7 \\
\hline Currency and deposits & 0.0 & -162.6 & 3.0 & 87.0 & 0.0 & 0.0 & 0.0 & 0.0 & 0.0 & 0.0 & -27.0 & 0.0 & 0.0 \\
\hline Debt securities & 0.0 & 0.0 & 0.0 & 0.0 & 0.0 & 0.0 & 0.0 & 0.0 & 0.0 & 0.0 & 0.0 & 0.0 & 0.0 \\
\hline Loans & -38.5 & -69.7 & -54.8 & -39.9 & -21.0 & -21.0 & -41.9 & -41.9 & -62.9 & -62.9 & -74.9 & -72.6 & -146.7 \\
\hline Equity and investment fund shares & 12.0 & -5.6 & -0.5 & 1.0 & 0.3 & 0.0 & 0.6 & 0.0 & 3.0 & 0.0 & -7.1 & 0.0 & 0.0 \\
\hline Insurance, pensions, and standardized guarantee schemes & 0.0 & 0.0 & 0.0 & 0.0 & 0.0 & 0.0 & 0.0 & 0.0 & 0.0 & 0.0 & 0.0 & 0.0 & 0.0 \\
\hline Financial derivatives and employee stock options & 0.0 & 0.0 & 0.0 & 0.0 & 0.0 & 0.0 & 0.0 & 0.0 & 0.0 & 0.0 & 0.0 & 0.0 & 0.0 \\
\hline Other accounts receivable & 0.0 & 0.0 & 0.0 & 0.0 & 0.0 & 0.0 & 0.0 & 0.0 & 0.0 & 0.0 & 0.0 & 0.0 & 0.0 \\
\hline Foreign assets & 0.0 & 0.0 & 0.0 & 0.0 & 0.0 & 0.0 & 0.0 & 0.0 & 0.0 & 0.0 & 0.0 & 0.0 & 0.0 \\
\hline Net incurrence of liabilities & 171.7 & 69.8 & -44.2 & 11.7 & -15.9 & -73.0 & -126.7 & -161.5 & -229.5 & -290.5 & -248.7 & -259.9 & -271.9 \\
\hline Domestic liabilities & -271.5 & -8.2 & -111.5 & 13.5 & -9.1 & -68.3 & -18.4 & -74.2 & -76.2 & -131.5 & -166.5 & -177.2 & -124.4 \\
\hline Debt securities & 0.0 & 89.0 & 42.1 & 100.4 & 4.9 & -4.7 & 5.3 & -8.0 & -11.8 & -32.0 & 40.0 & 40.0 & 3.9 \\
\hline Issuance & 0.0 & 89.0 & 250.0 & 248.6 & 29.7 & 30.0 & 39.5 & 40.0 & 39.5 & 40.0 & 120.0 & 120.0 & 103.9 \\
\hline Amortization & 0.0 & 0.0 & -207.9 & -148.3 & -24.7 & -34.7 & -34.2 & -48.0 & -51.3 & -72.0 & -80.0 & -80.0 & -100.0 \\
\hline Government obligations under the Law on Internal Debt, iss & & & & & & & & & & & & & \\
\hline guarantees, and other obligations from previous years & -72.9 & -93.3 & -129.3 & -110.2 & -33.7 & -39.6 & -34.2 & -40.1 & -143.4 & -168.2 & -174.0 & -174.0 & -144.1 \\
\hline Loans & -96.5 & -8.8 & 0.0 & -5.6 & 0.0 & -1.6 & 0.0 & -0.7 & 0.0 & -0.4 & -5.0 & -15.7 & 15.8 \\
\hline Equity and investment fund shares & 0.0 & 0.0 & 0.0 & 0.0 & 0.0 & 0.0 & 0.0 & 0.0 & 0.0 & 0.0 & 0.0 & 0.0 & 0.0 \\
\hline Insurance, pensions, and standardized guarantee schemes & 0.0 & 0.0 & 0.0 & 0.0 & 0.0 & 0.0 & 0.0 & 0.0 & 0.0 & 0.0 & 0.0 & 0.0 & 0.0 \\
\hline Financial derivatives and employee stock options & 0.0 & 0.0 & 0.0 & 0.0 & 0.0 & 0.0 & 0.0 & 0.0 & 0.0 & 0.0 & 0.0 & 0.0 & 0.0 \\
\hline Other accounts payable & -102.2 & 4.9 & -24.3 & 29.0 & 19.7 & -22.5 & 10.4 & -25.4 & 79.0 & 69.2 & -27.5 & -27.4 & 0.0 \\
\hline Foreign liabilities & 443.2 & 78.0 & 67.3 & -1.8 & -6.8 & -4.6 & -108.2 & -87.3 & -153.3 & -159.1 & -82.1 & -82.7 & -147.5 \\
\hline Debt securities & 0.0 & 0.0 & 0.0 & 0.0 & 0.0 & 0.0 & 0.0 & 0.0 & 0.0 & 0.0 & 0.0 & 0.0 & 0.0 \\
\hline Loans & 443.2 & 78.0 & 67.3 & -1.8 & -6.8 & -4.6 & -108.2 & -87.3 & -153.3 & -159.1 & -82.1 & -82.7 & -147.5 \\
\hline Drawings & 576.7 & 226.0 & 268.6 & 191.8 & 58.5 & 58.5 & 82.3 & 102.2 & 125.3 & 118.1 & 340.2 & 340.2 & 307.4 \\
\hline For budget support ${ }^{1}$ & 322.7 & 0.1 & 0.0 & 0.0 & 0.0 & 0.0 & 0.0 & 0.0 & 0.0 & 0.0 & 0.0 & 0.0 & 0.0 \\
\hline For investment projects & 254.0 & 225.9 & 268.6 & 191.8 & 58.5 & 58.5 & 82.3 & 102.2 & 125.3 & 118.1 & 340.2 & 340.2 & 307.4 \\
\hline Amortization & 133.4 & 148.0 & 201.4 & 193.6 & 65.3 & 63.2 & 190.5 & 189.5 & 278.6 & 277.1 & 422.3 & 422.9 & 454.9 \\
\hline Equity and investment fund shares & 0.0 & 0.0 & 0.0 & 0.0 & 0.0 & 0.0 & 0.0 & 0.0 & 0.0 & 0.0 & 0.0 & 0.0 & 0.0 \\
\hline Insurance, pensions, and standardized guarantee schemes & 0.0 & 0.0 & 0.0 & 0.0 & 0.0 & 0.0 & 0.0 & 0.0 & 0.0 & 0.0 & 0.0 & 0.0 & 0.0 \\
\hline Financial derivatives and employee stock options & 0.0 & 0.0 & 0.0 & 0.0 & 0.0 & 0.0 & 0.0 & 0.0 & 0.0 & 0.0 & 0.0 & 0.0 & 0.0 \\
\hline Other accounts payable & 0.0 & 0.0 & 0.0 & 0.0 & 0.0 & 0.0 & 0.0 & 0.0 & 0.0 & 0.0 & 0.0 & 0.0 & 0.0 \\
\hline Financing gap & 0.0 & 0.0 & 216.6 & 157.6 & 53.8 & 109.8 & 107.6 & 160.9 & 174.9 & 224.8 & 300.8 & 347.4 & 227.3 \\
\hline Identified financing & 0.0 & 0.0 & 216.6 & 157.6 & 53.8 & 109.8 & 107.6 & 160.9 & 174.9 & 224.8 & 300.8 & 347.4 & 227.3 \\
\hline IMF & 0.0 & 0.0 & 157.9 & 157.6 & 53.8 & 51.1 & 107.6 & 102.2 & 174.9 & 166.1 & 242.1 & 230.0 & 128.3 \\
\hline WB & 0.0 & 0.0 & 0.0 & 0.0 & 0.0 & 0.0 & 0.0 & 0.0 & 0.0 & 0.0 & 0.0 & 0.0 & 99.0 \\
\hline EU & 0.0 & 0.0 & 58.7 & 0.0 & 0.0 & 58.7 & 0.0 & 58.7 & 0.0 & 58.7 & 58.7 & 117.4 & 0.0 \\
\hline Other & 0.0 & 0.0 & 0.0 & 0.0 & 0.0 & 0.0 & 0.0 & 0.0 & 0.0 & 0.0 & 0.0 & 0.0 & 0.0 \\
\hline Unidentified financing & 0.0 & 0.0 & 0.0 & 0.0 & 0.0 & 0.0 & 0.0 & 0.0 & 0.0 & 0.0 & 0.0 & 0.0 & 0.0 \\
\hline Statistical discrepancy & 45.8 & -25.0 & 0.0 & -4.3 & 0.0 & 0.0 & 0.0 & 0.0 & 0.0 & 0.0 & 0.0 & 0.0 & 0.0 \\
\hline Memorandum items & & & & & & & & & & & & & \\
\hline Indirect revenues & 1122.8 & 1090.8 & 1125.9 & 1124.1 & 266.2 & 263.4 & 602.9 & 599.2 & 938.3 & 927.8 & 1291.1 & 1283.6 & 1373.9 \\
\hline Net lending excluding externally-financed operations & 9.9 & -57.0 & 44.0 & 74.8 & 0.0 & 0.8 & 60.0 & 60.9 & 120.0 & 120.9 & 179.0 & 180.1 & 205.3 \\
\hline
\end{tabular}




\begin{tabular}{|c|c|c|c|c|c|c|c|c|c|c|c|c|c|}
\hline \multicolumn{14}{|c|}{$\begin{array}{l}\text { Table 5d. Republika Srpska: General Government Statement of Operations, 2010-14 } \\
\text { (KM million) }\end{array}$} \\
\hline & \multirow[t]{3}{*}{2010} & \multirow[t]{3}{*}{2011} & \multicolumn{2}{|c|}{2012} & \multicolumn{8}{|c|}{2013} & \multirow[t]{3}{*}{2014} \\
\hline & & & \multicolumn{2}{|c|}{ Dec. } & \multicolumn{2}{|c|}{ Mar. } & \multicolumn{2}{|c|}{ Jun. } & \multicolumn{2}{|c|}{ Sep. } & \multicolumn{2}{|c|}{ Dec. } & \\
\hline & & & $\mathrm{EBS} / 12 / 120$ & Prel. & EBS/12/161 & Proj. & EBS/12/161 & Proj. & $\mathrm{EBS} / 12 / 161$ & Proj. & EBS/12/161 & Proj. & \\
\hline Revenue & 3407.8 & 3873.7 & 3862.9 & 3823.7 & 884.0 & 886.5 & 1885.3 & 1893.8 & 2843.3 & 2848.4 & 3948.2 & 3936.2 & 4156.1 \\
\hline Taxes & 1638.5 & 1881.6 & 1857.1 & 1857.2 & 424.2 & 420.0 & 895.7 & 887.2 & 1381.6 & 1361.3 & 1886.0 & 1860.5 & 1975.7 \\
\hline Direct taxes & 304.4 & 421.6 & 431.6 & 422.3 & 102.7 & 101.4 & 215.0 & 212.4 & 295.5 & 292.1 & 429.0 & 416.3 & 437.5 \\
\hline Indirect taxes & 1334.1 & 1452.4 & 1422.7 & 1430.2 & 320.8 & 318.1 & 679.6 & 674.1 & 1084.2 & 1068.1 & 1454.2 & 1442.1 & 1537.3 \\
\hline Other taxes & 0.0 & 7.5 & 2.8 & 4.7 & 0.7 & 0.5 & 1.1 & 0.7 & 1.9 & 1.2 & 2.7 & 2.1 & 0.9 \\
\hline Social security contributions & 1154.0 & 1365.7 & 1392.1 & 1346.2 & 318.2 & 319.8 & 699.9 & 703.2 & 1010.2 & 1015.2 & 1400.9 & 1400.4 & 1494.3 \\
\hline Grants & 189.1 & 176.0 & 171.2 & 190.0 & 46.8 & 46.8 & 93.5 & 93.5 & 140.3 & 140.3 & 187.0 & 187.0 & 202.2 \\
\hline Other revenue & 426.1 & 460.7 & 439.1 & 430.3 & 94.7 & 100.1 & 196.2 & 209.9 & 311.2 & 331.6 & 474.3 & 488.2 & 483.8 \\
\hline Expenditure & 4056.3 & 4133.4 & 4105.8 & 4111.5 & 895.7 & 893.5 & 1922.1 & 1917.1 & 3018.1 & 2996.6 & 4056.6 & 4079.1 & 4259.7 \\
\hline Expense & 3175.8 & 3443.8 & 3492.8 & 3507.5 & 823.2 & 820.9 & 1702.9 & 1703.1 & 2596.6 & 2592.8 & 3532.7 & 3543.7 & 3598.4 \\
\hline Compensation of employees & 829.1 & 934.1 & 949.4 & 950.3 & 218.8 & 216.9 & 446.8 & 442.7 & 666.2 & 660.0 & 891.9 & 889.4 & 861.4 \\
\hline Use of goods and services & 757.9 & 928.1 & 943.7 & 970.2 & 223.1 & 224.5 & 462.7 & 466.6 & 714.0 & 720.2 & 970.4 & 1007.4 & 1058.9 \\
\hline Social benefits & 1225.4 & 1211.9 & 1225.8 & 1233.3 & 299.7 & 307.7 & 602.0 & 618.1 & 928.5 & 953.1 & 1289.3 & 1296.8 & 1310.3 \\
\hline Interest & 57.4 & 67.4 & 102.4 & 90.7 & 20.4 & 21.3 & 53.7 & 55.8 & 74.1 & 77.4 & 115.6 & 111.0 & 115.1 \\
\hline Subsidies & 158.0 & 180.1 & 133.2 & 124.8 & 42.7 & 34.6 & 82.0 & 69.1 & 130.3 & 106.3 & 155.6 & 132.4 & 139.2 \\
\hline Other expense & 148.0 & 122.2 & 138.2 & 138.2 & 18.5 & 15.9 & 55.8 & 50.8 & 83.6 & 75.7 & 110.0 & 106.6 & 113.5 \\
\hline Net acquisition of nonfinancial assets & 880.5 & 689.6 & 613.1 & 604.1 & 72.4 & 72.6 & 219.2 & 214.0 & 421.5 & 403.7 & 523.9 & 535.4 & 661.3 \\
\hline Acquisition of nonfinancial assets & 880.5 & 712.5 & 639.8 & 625.6 & 79.0 & 86.1 & 231.4 & 230.8 & 438.6 & 431.9 & 601.1 & 605.4 & 683.0 \\
\hline Foreign financed capital spending & 350.6 & 295.6 & 362.1 & 308.3 & 53.6 & 59.8 & 108.2 & 119.7 & 184.1 & 204.2 & 271.3 & 313.7 & 350.3 \\
\hline Domestically financed capital spending & 530.0 & 416.9 & 277.8 & 317.3 & 25.4 & 26.3 & 123.2 & 111.1 & 254.5 & 227.8 & 329.7 & 291.7 & 332.7 \\
\hline Disposal of nonfinancial assets & 0.0 & 22.9 & 26.7 & 21.5 & 6.6 & 13.5 & 12.2 & 16.8 & 17.1 & 28.2 & 77.2 & 70.0 & 21.7 \\
\hline Gross / Net Operating Balance (revenue minus expense) & 232.0 & 429.9 & 370.1 & 316.2 & 60.7 & 65.7 & 182.4 & 190.7 & 246.7 & 255.5 & 415.5 & 392.4 & 557.7 \\
\hline Net lending/borrowing (revenue minus expenditure) & -648.5 & -259.7 & -242.9 & -287.8 & -11.7 & -6.9 & -36.8 & -23.3 & -174.8 & -148.2 & -108.4 & -143.0 & -103.6 \\
\hline Net acquisition of financial assets & 120.1 & 94.2 & 315.6 & 182.1 & 54.1 & 74.5 & 69.9 & 83.3 & 64.4 & 88.7 & 127.9 & 154.1 & 135.9 \\
\hline Domestic assets & 120.1 & 94.2 & 315.6 & 182.1 & 54.1 & 74.5 & 69.9 & 83.3 & 64.4 & 88.7 & 127.9 & 154.1 & 135.9 \\
\hline Currency and deposits & 0.0 & -113.9 & 9.0 & -22.9 & -13.7 & 0.3 & -42.5 & -4.2 & -63.9 & -19.7 & -77.0 & -32.8 & 39.5 \\
\hline Debt securities & 0.0 & 0.4 & 0.0 & 0.0 & 0.0 & 0.0 & 0.0 & 0.0 & 0.0 & 0.0 & 0.0 & 0.0 & 0.0 \\
\hline Loans & 116.1 & 106.7 & 290.8 & 154.4 & 63.2 & 81.1 & 90.3 & 77.5 & 101.6 & 101.0 & 170.1 & 173.0 & 104.5 \\
\hline Equity and investment fund shares & 4.0 & 78.2 & 15.7 & 43.4 & 4.6 & 2.8 & 22.1 & 22.1 & 26.6 & 22.1 & 34.7 & 21.6 & 0.0 \\
\hline Insurance, pensions, and standardized guarantee schemes & 0.0 & 0.0 & 0.0 & 0.0 & 0.0 & 0.0 & 0.0 & 0.0 & 0.0 & 0.0 & 0.0 & 0.0 & 0.0 \\
\hline Financial derivatives and employee stock options & 0.0 & 0.0 & 0.0 & 0.0 & 0.0 & 0.0 & 0.0 & 0.0 & 0.0 & 0.0 & 0.0 & 0.0 & 0.0 \\
\hline Other accounts receivable & 0.0 & 5.6 & 0.0 & 7.1 & 0.0 & -9.7 & 0.0 & -12.2 & 0.0 & -14.6 & 0.0 & -7.7 & -8.1 \\
\hline Foreign assets & 0.0 & 0.0 & 0.0 & 0.0 & 0.0 & 0.0 & 0.0 & 0.0 & 0.0 & 0.0 & 0.0 & 0.0 & 0.0 \\
\hline Net incurrence of liabilities & 711.8 & 326.1 & 450.3 & 383.3 & 38.9 & 26.6 & 52.9 & 26.0 & 151.8 & 124.5 & 85.8 & 123.3 & 125.8 \\
\hline Domestic liabilities & 452.0 & 166.1 & -10.9 & 136.3 & 1.2 & -11.2 & 17.1 & -9.8 & 93.3 & 66.0 & -59.2 & -21.7 & -23.7 \\
\hline Debt securities & 0.0 & 166.5 & 25.2 & -13.8 & 0.0 & 0.0 & -1.3 & -1.3 & -1.3 & -1.3 & -56.8 & -56.8 & 16.2 \\
\hline Issuance & 0.0 & 207.7 & 107.2 & 128.7 & 24.6 & 24.6 & 67.0 & 67.0 & 67.0 & 67.0 & 67.0 & 67.0 & 84.5 \\
\hline Amortization & 0.0 & 41.2 & -82.0 & -142.6 & 24.6 & 24.6 & 68.3 & 68.3 & 68.3 & 68.3 & 123.8 & 123.8 & 68.3 \\
\hline \multicolumn{14}{|l|}{$\begin{array}{l}\text { Government obligations under the Law on Internal Debt, } \\
\text { issued guarantees, and other obligations from previous years }\end{array}$} \\
\hline & -58.1 & -159.6 & -140.8 & -113.1 & -39.8 & -39.1 & -51.8 & -50.5 & -71.0 & -68.8 & -82.4 & -82.4 & -76.0 \\
\hline Loans & 510.3 & 117.7 & 104.7 & 182.0 & -10.6 & -1.0 & -9.6 & 11.4 & -21.0 & 11.1 & 80.0 & 163.8 & 36.3 \\
\hline Equity and investment fund shares & 0.0 & 0.0 & 0.0 & 0.0 & 0.0 & 0.0 & 0.0 & 0.0 & 0.0 & 0.0 & 0.0 & 0.0 & 0.0 \\
\hline Insurance, pensions, and standardized guarantee schemes & 0.0 & 0.0 & 0.0 & 0.0 & 0.0 & 0.0 & 0.0 & 0.0 & 0.0 & 0.0 & 0.0 & 0.0 & 0.0 \\
\hline Financial derivatives and employee stock options & 0.0 & 0.0 & 0.0 & 0.0 & 0.0 & 0.0 & 0.0 & 0.0 & 0.0 & 0.0 & 0.0 & 0.0 & 0.0 \\
\hline Other accounts payable & -0.2 & 40.5 & 0.0 & 81.2 & 51.5 & 28.9 & 79.8 & 30.7 & 186.6 & 125.0 & -0.1 & -46.3 & -0.2 \\
\hline Foreign liabilities & 259.8 & 160.0 & 461.2 & 247.0 & 37.7 & 37.7 & 35.8 & 35.8 & 58.5 & 58.5 & 145.0 & 145.0 & 149.5 \\
\hline Debt securities & 0.0 & 0.0 & 0.0 & 0.0 & 0.0 & 0.0 & 0.0 & 0.0 & 0.0 & 0.0 & 0.0 & 0.0 & 0.0 \\
\hline Loans & 259.8 & 160.0 & 460.5 & 247.0 & 37.7 & 37.7 & 35.8 & 35.8 & 58.5 & 58.5 & 145.0 & 145.0 & 149.5 \\
\hline Drawings & 338.3 & 255.1 & 575.8 & 363.7 & 69.3 & 69.3 & 135.4 & 135.4 & 203.9 & 203.9 & 361.1 & 361.1 & 380.7 \\
\hline For budget support & 176.8 & 0.0 & 0.0 & 0.0 & 0.0 & 0.0 & 0.0 & 0.0 & 0.0 & 0.0 & 0.0 & 0.0 & 0.0 \\
\hline For investment projects & 161.5 & 255.1 & 575.8 & 363.7 & 69.3 & 69.3 & 135.4 & 135.4 & 203.9 & 203.9 & 361.1 & 361.1 & 380.7 \\
\hline Amortization & 78.4 & 95.1 & 115.3 & 116.7 & 31.6 & 31.6 & 99.6 & 99.6 & 145.4 & 145.4 & 216.1 & 216.1 & 231.3 \\
\hline Equity and investment fund shares & 0.0 & 0.0 & 0.0 & 0.0 & 0.0 & 0.0 & 0.0 & 0.0 & 0.0 & 0.0 & 0.0 & 0.0 & 0.0 \\
\hline Insurance, pensions, and standardized guarantee schemes & 0.0 & 0.0 & 0.0 & 0.0 & 0.0 & 0.0 & 0.0 & 0.0 & 0.0 & 0.0 & 0.0 & 0.0 & 0.0 \\
\hline Financial derivatives and employee stock options & 0.0 & 0.0 & 0.0 & 0.0 & 0.0 & 0.0 & 0.0 & 0.0 & 0.0 & 0.0 & 0.0 & 0.0 & 0.0 \\
\hline Other accounts payable & 0.0 & 0.0 & 0.7 & 0.0 & 0.0 & 0.0 & 0.0 & 0.0 & 0.0 & 0.0 & 0.0 & 0.0 & 0.0 \\
\hline Statistical discrepancy / financing gap & 56.8 & 27.7 & 108.3 & 86.7 & 26.9 & 54.9 & 53.8 & 80.5 & 87.4 & 112.4 & 150.5 & 173.7 & 113.6 \\
\hline
\end{tabular}




\begin{tabular}{|c|c|c|c|c|c|c|c|c|c|c|c|c|c|}
\hline \multicolumn{14}{|c|}{$\begin{array}{l}\text { Table 5e.Republika Srpska: Consolidated Central Government Statement of Operations, 2010-14 } \\
\qquad \text { (KM million) }\end{array}$} \\
\hline & \multirow[t]{3}{*}{2010} & \multirow[t]{3}{*}{2011} & \multirow{2}{*}{\multicolumn{2}{|c|}{$\frac{2012}{\text { Dec. }}$}} & \multirow{2}{*}{\multicolumn{2}{|c|}{ Mar. }} & \multicolumn{4}{|c|}{2013} & & & 2014 \\
\hline & & & & & & & Jun. & & Sep. & & Dec. & & \\
\hline & & & EBS/12/120 & Prel. & EBS/12/161 & Proj. & EBS/12/161 & Proj. & $\mathrm{EBS} / 12 / 161$ & Proj. & EBS/12/161 & Proj. & \\
\hline Revenue & 1620.1 & 1880.4 & 1776.6 & 1860.9 & 414.2 & 409.3 & 871.9 & 862.2 & 1345.6 & 1325.7 & 1861.7 & 1863.5 & 1946.3 \\
\hline Taxes & 1252.5 & 1440.0 & 1380.6 & 1437.1 & 323.3 & 319.4 & 691.3 & 683.7 & 1050.6 & 1034.0 & 1426.9 & 1418.6 & 1507.6 \\
\hline Direct taxes & 246.7 & 340.3 & 340.3 & 345.0 & 86.6 & 84.9 & 179.6 & 176.4 & 239.6 & 235.1 & 334.6 & 334.6 & 351.7 \\
\hline Indirect taxes & 1005.8 & 1094.7 & 1038.9 & 1088.2 & 236.3 & 234.3 & 511.1 & 507.1 & 809.9 & 798.5 & 1091.0 & 1082.8 & 1156.0 \\
\hline Other taxes & 0.0 & 5.0 & 1.4 & 3.9 & 0.4 & 0.1 & 0.6 & 0.2 & 1.1 & 0.4 & 1.3 & 1.3 & 0.0 \\
\hline Social security contributions & 0.0 & 0.0 & 0.0 & 0.0 & 0.0 & 0.0 & 0.0 & 0.0 & 0.0 & 0.0 & 0.0 & 0.0 & 0.0 \\
\hline Grants & 189.1 & 171.7 & 171.2 & 177.9 & 46.8 & 46.8 & 93.5 & 93.5 & 140.3 & 140.3 & 187.0 & 187.0 & 202.2 \\
\hline Other revenue & 178.5 & 268.7 & 224.7 & 246.0 & 44.1 & 43.1 & 87.1 & 85.1 & 154.6 & 151.4 & 247.8 & 257.8 & 236.4 \\
\hline Expenditure & 2059.1 & 2013.1 & 1941.5 & 1935.2 & 407.6 & 405.7 & 871.4 & 868.6 & 1334.0 & 1325.4 & 1804.2 & 1805.4 & 1932.8 \\
\hline Expense & 1547.1 & 1729.8 & 1614.3 & 1653.8 & 355.9 & 353.0 & 744.0 & 737.0 & 1143.0 & 1132.9 & 1566.2 & 1566.2 & 1592.9 \\
\hline Compensation of employees & 620.3 & 713.4 & 716.2 & 721.4 & 164.9 & 163.7 & 332.1 & 329.7 & 493.0 & 489.4 & 659.7 & 659.7 & 659.7 \\
\hline Use of goods and services & 93.1 & 163.1 & 150.1 & 149.8 & 19.9 & 18.9 & 55.9 & 54.9 & 108.7 & 107.8 & 155.5 & 155.5 & 163.5 \\
\hline Social benefits & 206.7 & 275.9 & 250.2 & 250.3 & 60.9 & 61.5 & 103.5 & 104.3 & 169.5 & 170.8 & 255.0 & 255.0 & 258.7 \\
\hline Interest & 36.2 & 46.0 & 63.6 & 68.2 & 15.8 & 15.7 & 42.2 & 42.1 & 56.9 & 56.7 & 83.4 & 83.4 & 86.1 \\
\hline Subsidies & 157.9 & 165.6 & 117.5 & 107.6 & 30.0 & 30.0 & 60.0 & 60.0 & 92.6 & 92.6 & 114.2 & 114.2 & 120.0 \\
\hline Transfers to other general government units & 350.7 & 304.4 & 253.7 & 282.9 & 61.0 & 60.4 & 125.0 & 123.5 & 189.2 & 186.8 & 254.8 & 254.8 & 259.5 \\
\hline Other expense & 82.1 & 61.4 & 63.0 & 73.6 & 3.4 & 2.8 & 25.3 & 22.4 & 33.1 & 28.7 & 43.7 & 43.7 & 45.5 \\
\hline Net acquisition of nonfinancial assets & 512.0 & 283.4 & 327.2 & 281.3 & 51.7 & 52.8 & 127.5 & 131.7 & 191.0 & 192.5 & 238.0 & 239.2 & 340.0 \\
\hline Acquisition of nonfinancial assets & 512.0 & 293.8 & 332.2 & 288.4 & 52.7 & 60.6 & 130.9 & 139.6 & 195.6 & 207.9 & 292.7 & 293.9 & 345.7 \\
\hline Foreign financed capital spending & 292.8 & 201.3 & 258.5 & 219.1 & 50.2 & 54.2 & 103.0 & 111.2 & 158.7 & 171.3 & 249.5 & 249.5 & 282.9 \\
\hline Domestically financed capital spending & 219.2 & 92.5 & 73.8 & 69.3 & 2.5 & 6.4 & 27.9 & 28.4 & 36.9 & 36.6 & 43.2 & 44.4 & 62.7 \\
\hline Disposal of nonfinancial assets & 0.0 & 10.5 & 5.1 & 7.1 & 1.0 & 7.9 & 3.4 & 7.9 & 4.6 & 15.4 & 54.7 & 54.7 & 5.7 \\
\hline Gross / Net Operating Balance (revenue minus expense) & 73.0 & 150.6 & 162.2 & 207.1 & 58.2 & 56.4 & 127.9 & 125.3 & 202.6 & 192.7 & 295.5 & 297.3 & 353.4 \\
\hline Net lending/borrowing (revenue minus expenditure) & -439.0 & -132.8 & -164.9 & -74.2 & 6.6 & 3.6 & 0.5 & -6.4 & 11.6 & 0.3 & 57.5 & 58.1 & 13.4 \\
\hline Net acquisition of financial assets & 121.4 & 217.6 & 295.7 & 350.2 & 37.0 & 75.3 & 63.6 & 68.5 & 68.0 & 80.2 & 106.7 & 130.0 & 129.8 \\
\hline Domestic assets & 121.4 & 217.6 & 295.7 & 350.2 & 37.0 & 75.3 & 63.6 & 68.5 & 68.0 & 80.2 & 106.7 & 130.0 & 129.8 \\
\hline Currency and deposits & 0.0 & -127.6 & -80.9 & -34.2 & -21.9 & 0.0 & -21.9 & 0.0 & -21.9 & 0.0 & -36.4 & 0.0 & 0.0 \\
\hline Debt securities & 0.0 & 0.4 & 0.0 & 0.0 & 0.0 & 0.0 & 0.0 & 0.0 & 0.0 & 0.0 & 0.0 & 0.0 & 0.0 \\
\hline Loans & 117.4 & 282.1 & 360.9 & 322.3 & 54.3 & 72.4 & 63.4 & 46.4 & 63.3 & 58.1 & 108.4 & 108.4 & 129.8 \\
\hline Equity and investment fund shares & 4.0 & 75.4 & 15.7 & 43.4 & 4.6 & 2.8 & 22.1 & 22.1 & 26.6 & 22.1 & 34.7 & 21.6 & 0.0 \\
\hline Insurance, pensions, and standardized guarantee schemes & 0.0 & 0.0 & 0.0 & 0.0 & 0.0 & 0.0 & 0.0 & 0.0 & 0.0 & 0.0 & 0.0 & 0.0 & 0.0 \\
\hline Financial derivatives and employee stock options & 0.0 & 0.0 & 0.0 & 0.0 & 0.0 & 0.0 & 0.0 & 0.0 & 0.0 & 0.0 & 0.0 & 0.0 & 0.0 \\
\hline Other accounts receivable & 0.0 & -12.6 & 0.0 & 18.7 & 0.0 & 0.0 & 0.0 & 0.0 & 0.0 & 0.0 & 0.0 & 18.7 & 0.0 \\
\hline Foreign assets & 0.0 & 0.0 & 0.0 & 0.0 & 0.0 & 0.0 & 0.0 & 0.0 & 0.0 & 0.0 & 0.0 & 0.0 & 0.0 \\
\hline Net incurrence of liabilities & 576.9 & 343.1 & 352.4 & 339.8 & 3.5 & 16.8 & 9.3 & -5.6 & -31.0 & -32.5 & -101.2 & -101.8 & 2.7 \\
\hline Domestic liabilities & 374.9 & 177.7 & 7.1 & 139.5 & -34.3 & -21.0 & -26.5 & -41.4 & -89.5 & -91.1 & -156.2 & -156.8 & -56.7 \\
\hline Debt securities & 0.0 & 161.3 & 20.5 & -13.9 & 0.0 & 0.0 & -1.3 & -1.3 & -1.3 & -1.3 & -56.8 & -56.8 & 16.2 \\
\hline Issuance & 0.0 & 196.9 & 100.0 & 125.0 & 24.6 & 24.6 & 67.0 & 67.0 & 67.0 & 67.0 & 67.0 & 67.0 & 84.5 \\
\hline Amortization & 0.0 & 35.6 & 79.5 & 138.9 & 24.6 & 24.6 & 68.3 & 68.3 & 68.3 & 68.3 & 123.8 & 123.8 & 68.3 \\
\hline Government obligations under the Law on Internal Debt, & & & & & & & & & & & & & \\
\hline issued guarantees, and other obligations from previous years & -58.1 & -88.5 & -77.9 & -62.0 & -38.7 & -38.7 & -50.0 & -50.0 & -67.8 & -67.8 & -77.4 & -77.4 & -70.3 \\
\hline Loans & 461.3 & 73.0 & 64.5 & 147.1 & -11.1 & -12.1 & -10.6 & -11.8 & -22.5 & -23.8 & -22.0 & -22.6 & -2.6 \\
\hline Equity and investment fund shares & 0.0 & 0.0 & 0.0 & 0.0 & 0.0 & 0.0 & 0.0 & 0.0 & 0.0 & 0.0 & 0.0 & -0.6 & 0.0 \\
\hline Insurance, pensions, and standardized guarantee schemes & 0.0 & 0.0 & 0.0 & 0.0 & 0.0 & 0.0 & 0.0 & 0.0 & 0.0 & 0.0 & 0.0 & 0.0 & 0.0 \\
\hline Financial derivatives and employee stock options & 0.0 & 0.0 & 0.0 & 0.0 & 0.0 & 0.0 & 0.0 & 0.0 & 0.0 & 0.0 & 0.0 & 0.0 & 0.0 \\
\hline Other accounts payable & -28.3 & 31.9 & 0.0 & 68.3 & 15.6 & 29.9 & 35.4 & 21.7 & 2.0 & 1.8 & 0.0 & 0.0 & 0.0 \\
\hline Foreign liabilities & 202.0 & 165.3 & 345.3 & 200.3 & 37.7 & 37.7 & 35.8 & 35.8 & 58.5 & 58.5 & 55.0 & 55.0 & 59.5 \\
\hline Debt securities & 0.0 & 0.0 & 0.0 & 0.0 & 0.0 & 0.0 & 0.0 & 0.0 & 0.0 & 0.0 & 0.0 & 0.0 & 0.0 \\
\hline Loans & 202.0 & 165.3 & 345.3 & 200.3 & 37.7 & 37.7 & 35.8 & 35.8 & 58.5 & 58.5 & 55.0 & 55.0 & 59.5 \\
\hline Drawings & 280.5 & 255.9 & 455.8 & 312.2 & 69.3 & 69.3 & 135.4 & 135.4 & 203.9 & 203.9 & 271.1 & 271.1 & 290.7 \\
\hline For budget support & 176.8 & 0.0 & 0.0 & 0.0 & 0.0 & 0.0 & 0.0 & 0.0 & 0.0 & 0.0 & 0.0 & 0.0 & 0.0 \\
\hline For investment projects & 103.7 & 255.9 & 455.8 & 312.2 & 69.3 & 69.3 & 135.4 & 135.4 & 203.9 & 203.9 & 271.1 & 271.1 & 290.7 \\
\hline Amortization & 78.4 & 90.6 & 110.5 & 111.9 & 31.6 & 31.6 & 99.6 & 99.6 & 145.4 & 145.4 & 216.1 & 216.1 & 231.3 \\
\hline Equity and investment fund shares & 0.0 & 0.0 & 0.0 & 0.0 & 0.0 & 0.0 & 0.0 & 0.0 & 0.0 & 0.0 & 0.0 & 0.0 & 0.0 \\
\hline Insurance, pensions, and standardized guarantee schemes & 0.0 & 0.0 & 0.0 & 0.0 & 0.0 & 0.0 & 0.0 & 0.0 & 0.0 & 0.0 & 0.0 & 0.0 & 0.0 \\
\hline Financial derivatives and employee stock options & 0.0 & 0.0 & 0.0 & 0.0 & 0.0 & 0.0 & 0.0 & 0.0 & 0.0 & 0.0 & 0.0 & 0.0 & 0.0 \\
\hline Other accounts payable & 0.0 & 0.0 & 0.0 & 0.0 & 0.0 & 0.0 & 0.0 & 0.0 & 0.0 & 0.0 & 0.0 & 0.0 & 0.0 \\
\hline Financing gap & 0.0 & 0.0 & 108.3 & 78.8 & 26.9 & 54.9 & 53.8 & 80.4 & 87.4 & 112.4 & 150.4 & 173.7 & 113.6 \\
\hline Identified financing & 0.0 & 0.0 & 108.3 & 78.8 & 26.9 & 54.9 & 53.8 & 80.5 & 87.4 & 112.4 & 150.4 & 173.7 & 113.6 \\
\hline IMF & 0.0 & 0.0 & 79.0 & 78.8 & 26.9 & 25.6 & 53.8 & 51.1 & 87.4 & 83.1 & 121.1 & 115.0 & 64.2 \\
\hline WB & 0.0 & 0.0 & 0.0 & 0.0 & 0.0 & 0.0 & 0.0 & 0.0 & 0.0 & 0.0 & 0.0 & 0.0 & 49.5 \\
\hline EU & 0.0 & 0.0 & 29.3 & 0.0 & 0.0 & 29.3 & 0.0 & 29.3 & 0.0 & 29.3 & 29.3 & 58.7 & 0.0 \\
\hline Other & 0.0 & 0.0 & 0.0 & 0.0 & 0.0 & 0.0 & 0.0 & 0.0 & 0.0 & 0.0 & 0.0 & 0.0 & 0.0 \\
\hline Undentified financing & 0.0 & 0.0 & 0.0 & 0.0 & 0.0 & 0.0 & 0.0 & 0.0 & 0.0 & 0.0 & 0.0 & 0.0 & 0.0 \\
\hline Statistical discrepancy & -16.5 & 7.3 & 0.0 & 5.8 & 0.0 & 0.0 & 0.0 & 0.0 & 0.0 & 0.0 & 0.0 & 0.0 & 0.0 \\
\hline Memorandum items & & & & & & & & & & & & & \\
\hline Indirect revenues & 1005.8 & 1094.7 & 1038.9 & 1088.2 & 236.3 & 234.3 & 511.1 & 507.1 & 809.9 & 798.5 & 1091.0 & 1082.8 & 1156.0 \\
\hline Net lending excluding externally-financed operations & -335.3 & -103.1 & -77.7 & -33.0 & 10.0 & 11.0 & 10.0 & 11.3 & 30.0 & 31.3 & 120.0 & 120.6 & 94.1 \\
\hline
\end{tabular}




\begin{tabular}{|c|c|c|c|c|c|}
\hline \multicolumn{6}{|c|}{ Table 6. Bosnia and Herzegovina: Monetary Survey, 2010-14 } \\
\hline & 2010 & 2011 & 2012 & 2013 & 2014 \\
\hline & $\mathrm{Dec}$ & $\mathrm{Dec}$ & $\mathrm{Dec}$ & \multicolumn{2}{|c|}{ Dec } \\
\hline & & & & \multicolumn{2}{|c|}{ Proj. } \\
\hline & \multicolumn{5}{|c|}{ (Million $\mathrm{KM}$, end of period) } \\
\hline Net foreign assets & 4,518 & 4,999 & 5,102 & 5,206 & 5,261 \\
\hline Foreign assets & 9,302 & 9,177 & 9,034 & 9,177 & 9,488 \\
\hline Foreign liabilities & 4,784 & 4,177 & 3,932 & 3,971 & 4,227 \\
\hline Net domestic assets & 9,110 & 9,420 & 9,811 & 10,434 & 11,177 \\
\hline Domestic credit & 13,494 & 14,683 & 15,423 & 16,256 & 16,883 \\
\hline Claims on general government (net) & -726 & -117 & 204 & 228 & -40 \\
\hline Claims on nongovernment & 14,219 & 14,800 & 15,219 & 16,029 & 16,924 \\
\hline Other items (net) & $-4,383$ & $-5,263$ & $-5,612$ & $-5,822$ & $-5,706$ \\
\hline Broad money (M2) & 13,628 & 14,418 & 14,910 & 15,640 & 16,439 \\
\hline Narrow money (M1) & 5,900 & 6,185 & 6,142 & 6,750 & 7,056 \\
\hline Currency & 2,211 & 2,366 & 2,414 & 2,792 & 2,878 \\
\hline Demand deposits & 3,689 & 3,819 & 3,727 & 3,959 & 4,178 \\
\hline Quasi-money (M1) & 7,728 & 8,233 & 8,768 & 8,889 & 9,383 \\
\hline Time and savings deposits & 1,991 & 2,286 & 2,673 & 2,549 & 2,690 \\
\hline \multirow[t]{2}{*}{ Foreign currency deposits } & 5,737 & 5,947 & 6,095 & 6,340 & 6,692 \\
\hline & \multicolumn{5}{|c|}{ (12-month change over broad money in same period last year, in percent) } \\
\hline Net foreign assets & 6.6 & 3.5 & 0.7 & 0.7 & 0.4 \\
\hline Net domestic assets & 0.6 & 2.3 & 2.7 & 4.2 & 4.8 \\
\hline Domestic credit & 6.0 & 8.7 & 5.1 & 5.6 & 4.0 \\
\hline Claims on general government (net) & 2.9 & 4.5 & 2.2 & 0.2 & -1.7 \\
\hline Claims on nongovernment & 3.0 & 4.3 & 2.9 & 5.4 & 5.7 \\
\hline Other items (net) & -5.3 & -6.5 & -2.4 & -1.4 & 0.7 \\
\hline Broad money (M2) & 7.2 & 5.8 & 3.4 & 4.9 & 5.1 \\
\hline \multicolumn{6}{|l|}{ Memorandum items: } \\
\hline & \multicolumn{5}{|c|}{ (Annual percent change) } \\
\hline Broad money (M2) & 7.2 & 5.8 & 3.4 & 4.9 & 5.1 \\
\hline Reserve money (RM) & 4.4 & -0.9 & -0.8 & 1.9 & 6.7 \\
\hline \multirow[t]{2}{*}{ Credit to the private sector ${ }^{1}$} & 2.1 & 4.2 & 2.8 & 5.6 & 5.9 \\
\hline & \multicolumn{5}{|c|}{ (Percent) } \\
\hline Credit to the private sector (in percent of GDP) & 54.4 & 54.7 & 54.7 & 54.7 & 55.1 \\
\hline Broad money (in percent of GDP) & 55.0 & 56.2 & 56.6 & 56.2 & 56.2 \\
\hline \multirow[t]{2}{*}{ Central bank net foreign assets (in percent of monetary } & 109.9 & 110.3 & 112.6 & 112.9 & 110.7 \\
\hline & \multicolumn{5}{|c|}{ (Ratio) } \\
\hline Velocity (GDP/end-of-period M2) & 1.8 & 1.8 & 1.8 & 1.8 & 1.8 \\
\hline Reserve money multiplier (M2/RM) & 2.3 & 2.5 & 2.6 & 2.6 & 2.6 \\
\hline
\end{tabular}




\begin{tabular}{|c|c|c|c|}
\hline \multicolumn{4}{|c|}{$\begin{array}{l}\text { Table 7. Bosnia and Herzegovina: Schedule of Purchases } \\
\text { Under the Stand-By Arrangement, 2012-14 }\end{array}$} \\
\hline \multirow[b]{2}{*}{$\begin{array}{l}\text { Available on } \\
\text { or after }\end{array}$} & \multicolumn{2}{|c|}{ Amount of Purchase } & \multirow[b]{2}{*}{ Conditions } \\
\hline & $\begin{array}{l}\text { In millions } \\
\text { of SDRs }\end{array}$ & $\begin{array}{l}\text { In percent } \\
\text { of quota }^{1}\end{array}$ & \\
\hline 1 September 26, 2012 & 50.730 & 30 & Board approval of the arrangement. \\
\hline 2 December 15, 2012 & 50.730 & 30 & $\begin{array}{l}\text { Observance of end-September } 2012 \text { performance criteria and } \\
\text { completion of the first program review. }\end{array}$ \\
\hline 3 March 15, 2013 & 33.820 & 20 & $\begin{array}{l}\text { Observance of end-December } 2012 \text { performance criteria, and } \\
\text { completion of the quarterly program review. }\end{array}$ \\
\hline 4 June 15, 2013 & 33.820 & 20 & $\begin{array}{l}\text { Observance of end-March } 2013 \text { performance criteria and } \\
\text { completion of the quarterly program review. }\end{array}$ \\
\hline 5 September 15, 2013 & 42.275 & 25 & $\begin{array}{l}\text { Observance of end-June } 2013 \text { performance criteria and } \\
\text { completion of the quarterly program review. }\end{array}$ \\
\hline 6 December 15, 2013 & 42.275 & 25 & $\begin{array}{l}\text { Observance of end-September } 2013 \text { performance criteria and } \\
\text { completion of the quarterly program review. }\end{array}$ \\
\hline 7 March 15, 2014 & 42.275 & 25 & $\begin{array}{l}\text { Observance of end-December } 2013 \text { performance criteria and } \\
\text { completion of the quarterly program review. }\end{array}$ \\
\hline 8 June 15, 2014 & 42.275 & 25 & $\begin{array}{l}\text { Observance of end-March } 2014 \text { performance criteria and } \\
\text { completion of the quarterly program review. }\end{array}$ \\
\hline Total & 338.20 & 200.00 & \\
\hline
\end{tabular}




\begin{tabular}{|c|c|c|c|c|c|c|c|c|c|}
\hline \multicolumn{10}{|c|}{$\begin{array}{l}\text { Table 8. Bosnia and Herzegovina: Quantitative Performance Criteria and Indicative Target Under th } \\
\text { (Cumulative flow since the end of the previous year; in millions of KM) }\end{array}$} \\
\hline & \multicolumn{4}{|c|}{2012} & \multicolumn{5}{|c|}{2013} \\
\hline & \multicolumn{2}{|c|}{ End-September } & \multicolumn{2}{|c|}{ End-December } & \multicolumn{2}{|c|}{ End-March } & \multirow[t]{2}{*}{ End-June } & \multirow{2}{*}{$\begin{array}{c}\text { End-September } \\
\text { EBS/12/161 } \\
\end{array}$} & \multirow[t]{2}{*}{ End-December } \\
\hline & $\begin{array}{l}\mathrm{EBS} / 12 / 120 \\
\end{array}$ & Act. & EBS/12/120 & Act. & $\begin{array}{ll}\mathrm{EBS} / 12 / 161 \\
\end{array}$ & Act. & & & \\
\hline \multicolumn{10}{|l|}{ Performance Criteria } \\
\hline \multicolumn{10}{|l|}{ Floor on the net lending of $1 /$} \\
\hline Institutions of $\mathrm{BiH}$ & 10.7 & 47.6 & -38.2 & 44.5 & -15.0 & $\ldots$ & -15.0 & -20.0 & -25.0 \\
\hline Federation central government & 180.4 & 146.8 & 44.0 & 74.8 & 0.0 & $\ldots$ & 60.0 & 120.0 & 179.0 \\
\hline RS central government & 57.8 & 88.4 & -77.7 & -33.0 & 10.0 & $\ldots$ & 10.0 & 30.0 & 120.0 \\
\hline \multicolumn{10}{|c|}{$\begin{array}{l}\text { Ceiling on contracting and guaranteeing of new nonconcessional short-term external debt } \\
\text { by }\end{array}$} \\
\hline Institutions of $\mathrm{BiH}$ & 0 & 0 & 0 & 0 & 0 & 0 & 0 & 0 & 0 \\
\hline Federation general government & 0 & 0 & 0 & 0 & 0 & 0 & 0 & 0 & 0 \\
\hline RS general government & 0 & 0 & 0 & 0 & 0 & 0 & 0 & 0 & 0 \\
\hline $\mathrm{CBBH}$ & 0 & 0 & 0 & 0 & 0 & 0 & 0 & 0 & 0 \\
\hline \multicolumn{10}{|l|}{ Ceiling on accumulation of domestic arrears by $2 /$} \\
\hline Institutions of BiH & 0 & 0 & 0 & 0 & 0 & $\ldots$ & $\ldots$ & $\ldots$ & $\ldots$ \\
\hline Federation general government & 0 & 0 & 0 & $\ldots$ & 0 & $\ldots$ & $\ldots$ & $\ldots$ & $\ldots$ \\
\hline RS general government & 0 & 0 & 0 & $\ldots$ & 0 & $\ldots$ & $\ldots$ & $\ldots$ & $\ldots$ \\
\hline \multicolumn{10}{|l|}{ Ceiling on accumulation of domestic arrears by $3 /$} \\
\hline Institutions of $\mathrm{BiH}$ & $\ldots$ & $\ldots$ & $\ldots$ & 0 & 0 & $\ldots$ & 0 & 0 & 0 \\
\hline Federation central government & $\ldots$ & $\ldots$ & $\ldots$ & 0 & 0 & $\ldots$ & 0 & 0 & 0 \\
\hline RS central government & $\ldots$ & $\ldots$ & $\ldots$ & 0 & 0 & & 0 & 0 & 0 \\
\hline \multicolumn{10}{|l|}{ Ceiling on accumulation external payment arrears by $4 /$} \\
\hline Institutions of BiH & 0 & 0 & 0 & 0 & 0 & 0 & 0 & 0 & 0 \\
\hline Federation general government & 0 & 0 & 0 & 0 & 0 & 0 & 0 & 0 & 0 \\
\hline RS general government & 0 & 0 & 0 & 0 & 0 & 0 & 0 & 0 & 0 \\
\hline CBBH & 0 & 0 & 0 & 0 & 0 & 0 & 0 & 0 & 0 \\
\hline \multicolumn{10}{|l|}{ Indicative targets } \\
\hline Floor on the net lending of the general government of $\mathrm{BiH} 1 /$ & 413.0 & 48.4 & -237.6 & -192.6 & -50.9 & $\ldots$ & -24.6 & -97.1 & -17.1 \\
\hline \multicolumn{10}{|l|}{ Ceiling on changes in the stock of "other accounts payable" 3 / } \\
\hline Federation general government & $\ldots$ & $\ldots$ & $\ldots$ & 16.9 & $\ldots$ & $\ldots$ & 100.0 & 100.0 & 100.0 \\
\hline RS general government & $\ldots$ & $\ldots$ & $\ldots$ & 81.2 & $\ldots$ & $\ldots$ & 160.0 & 160.0 & 160.0 \\
\hline \multicolumn{10}{|c|}{$\begin{array}{l}\text { 1/ Excluding foreign financed projects as defined in TMU. } \\
\text { 2/ The authorities requested modification of these performance criteria. } \\
\text { 3/ Proposed performance criteria and indicative targets, starting end-June } 2013 . \\
\text { 4/ Continuous. }\end{array}$} \\
\hline
\end{tabular}




\begin{tabular}{|c|c|c|c|}
\hline \multicolumn{4}{|c|}{ Table 9. Bosnia and Herzegovina: Structural Conditionality } \\
\hline Actions & Rationale & Test date & Status \\
\hline \multicolumn{4}{|l|}{ Prior Action for Board consideration of the second review } \\
\hline 1 Adopt a new law on privileged pensions in the Federation in line with IMF staff recommendations & $\begin{array}{l}\text { Reducing recurrent spending through better } \\
\text { targeting of transfer programs }\end{array}$ & & Met \\
\hline \multicolumn{4}{|l|}{ Structural benchmarks } \\
\hline 1 Continue to adhere to the Currency Board Arrangement as constituted under the law & $\begin{array}{l}\text { Anchor for macroeconomic policy; } \\
\text { contributing to economic and political } \\
\text { stability }\end{array}$ & Continuous & Met \\
\hline 2 Refrain from introducing new privileged or special rights for retirement & $\begin{array}{l}\text { Reducing recurrent spending through better } \\
\text { targeting of transfer programs }\end{array}$ & Continuous & Met \\
\hline $\begin{array}{l}3 \text { Publish on the web site of the Institutions of BiH quarterly consolidated general government accounts } \\
\text { with a } 6 \text { week lag }\end{array}$ & Fiscal transparency & Quarterly & $\begin{array}{l}\text { Met in September; not } \\
\text { met in December }\end{array}$ \\
\hline $\begin{array}{l}4 \text { Carry out eligibility audits for war benefit recipients; publish results (quarterly within } 4 \text { weeks after the } \\
\text { end of each quarter) of audits (Entities) }\end{array}$ & $\begin{array}{l}\text { Reducing recurrent spending through better } \\
\text { targeting of transfer programs }\end{array}$ & Quarterly & Met with delay \\
\hline $\begin{array}{l}5 \text { Pay obligations accrued through May } 2012 \text { arising from early retirement provisions under the Law on } \\
\text { Service in the Armed Forces of BiH }\end{array}$ & Arrear clearance & End-December 2012 & Met \\
\hline $\begin{array}{l}6 \text { Amend the Law on Financing of the Institutions of BiH to allow for continued servicing of foreign debt in } \\
\text { the absence of an adopted budget }\end{array}$ & $\begin{array}{l}\text { Contributing to economic and political } \\
\text { stability as well as to investor confidence }\end{array}$ & End-December 2012 & Met with delay \\
\hline $\begin{array}{l}7 \text { Amend the banking law in the Federation to limit provisional administration to one year with a possible } \\
\text { six month extension }\end{array}$ & $\begin{array}{l}\text { Strengthening bank supervision as well as } \\
\text { the bank resolution framework }\end{array}$ & End-December 2012 & $\begin{array}{l}\text { Not met; reset to end- } \\
\text { June } 2013\end{array}$ \\
\hline $\begin{array}{l}8 \text { Amend the banking law in the RS to limit provisional administration to one year with a possible six } \\
\text { month extension }\end{array}$ & $\begin{array}{l}\text { Strengthening bank supervision as well as } \\
\text { the bank resolution framework }\end{array}$ & End-December 2012 & $\begin{array}{l}\text { Not met; reset to end- } \\
\text { June } 2013\end{array}$ \\
\hline $\begin{array}{l}9 \text { Amend the legal frameworks related to the treatment of confidential information in the Federation and } \\
\text { the RS to align them with EU requirements }\end{array}$ & $\begin{array}{l}\text { Improving information sharing and policy } \\
\text { coordination }\end{array}$ & End-December 2012 & $\begin{array}{l}\text { Not met, reset to end- } \\
\text { June } 2013\end{array}$ \\
\hline $\begin{array}{l}10 \text { Sign a Memorandum of Understanding by the Ministry of Finance and Treasury of } \mathrm{BiH} \text {, the Ministry of } \\
\text { Finance of the Federation, the Ministry of Finance of the RS, and the } \mathrm{CBBH} \text {, which will regulate the } \\
\text { disbursements from and servicing of all related obligations to the IMF }\end{array}$ & Safeguarding Fund Resources & End-December 2012 & Met with delay \\
\hline $\begin{array}{l}11 \text { Adopt a new law on budget in the Federation that improves data reporting and enhancing control over } \\
\text { lower level governments, extra-budgetary funds, and public companies }\end{array}$ & Fiscal sustainability & End-March 2013 & $\begin{array}{l}\text { Not met, reset to end- } \\
\text { May } 2013\end{array}$ \\
\hline $\begin{array}{l}12 \text { Submit to the BiH Parliament a revised law governing the Deposit Insurance Agency along the lines } \\
\text { specified in } \llbracket 28 \text { of the LOI of September 11, } 2012\end{array}$ & $\begin{array}{l}\text { Improving crisis preparedness and } \\
\text { contingency planning }\end{array}$ & End-March 2013 & Met \\
\hline $\begin{array}{l}13 \text { Sign a joint Memorandum of Understanding by the four tax agencies (ITA, FTA, RSTA, and BDTA) on data } \\
\text { exchange to further improve the exchange of information }\end{array}$ & $\begin{array}{l}\text { Reducing tax evasion and enhancing policy } \\
\text { cooperation }\end{array}$ & End-May 2013 & \\
\hline 14 Establish a one-stop shop process for business registration in RS & Improving business environment & End-September 2013 & \\
\hline 15 Amend legislation in the RS to eliminate the take-home pay protection for public sector employees & $\begin{array}{l}\text { Controlling the public sector wage bill in the } \\
\text { medium term }\end{array}$ & End-December 2013 & \\
\hline
\end{tabular}

\section{(CInternational Monetary Fund. Not for Redistribution}




\begin{tabular}{|c|c|c|c|c|c|c|c|c|c|}
\hline & 2011 & 2012 & 2013 & 2014 & 2015 & 2016 & 2017 & 2018 & 2019 \\
\hline & \multicolumn{2}{|c|}{ Actual } & \multicolumn{7}{|c|}{ Projections } \\
\hline \multicolumn{10}{|l|}{ Fund repurchases and charges 1 / } \\
\hline In millions of SDRs & 4.8 & 24.3 & 142.1 & 151.4 & 42.6 & 76.6 & 149.5 & 97.2 & 16.1 \\
\hline In millions of U.S. dollars & 7.6 & 37.3 & 218.3 & 232.1 & 65.1 & 116.9 & 227.7 & 148.1 & 24.5 \\
\hline In percent of exports of goods and NFS & 0.1 & 0.7 & 4.0 & 3.9 & 1.0 & 1.7 & 3.2 & 1.9 & 0.3 \\
\hline In percent of external public debt service & 3.1 & 13.5 & 41.1 & 40.9 & 14.3 & 25.5 & 37.6 & 27.8 & 4.3 \\
\hline In percent of quota & 3.0 & 14.0 & 84.3 & 89.3 & 25.1 & 45.2 & 88.3 & 57.5 & 9.5 \\
\hline In percent of gross official reserves & 0.2 & 0.8 & 4.9 & 5.0 & 1.4 & 2.3 & 4.4 & 2.8 & 0.5 \\
\hline \multicolumn{10}{|l|}{ Fund credit outstanding $1 /$} \\
\hline In millions of SDRs & 338.2 & 416.8 & 432.1 & 370.3 & 331.9 & 258.9 & 112.0 & 15.9 & 0.0 \\
\hline In millions of U.S. dollars & 534.0 & 638.5 & 663.8 & 567.7 & 507.5 & 395.0 & 170.6 & 24.1 & 0.0 \\
\hline In percent of quota & 200.0 & 246.5 & 255.5 & 219.0 & 196.3 & 153.1 & 66.3 & 9.4 & 0.0 \\
\hline In percent of GDP & 2.9 & 3.7 & 3.5 & 2.9 & 2.4 & 1.8 & 0.7 & 0.1 & 0.0 \\
\hline In percent of gross official reserves & 12.3 & 14.6 & 14.8 & 12.2 & 10.5 & 7.9 & 3.3 & 0.5 & 0.0 \\
\hline \multicolumn{10}{|l|}{ Memorandum items: } \\
\hline Exports of goods and services (millions of US\$) & 5,713 & 5,043 & 5,458 & 5,877 & 6,297 & 6,722 & 7,205 & 7,723 & 8,278 \\
\hline External public debt service (millions of US\$) & 248 & 277 & 532 & 568 & 457 & 458 & 606 & 532 & 569 \\
\hline Quota (millions of SDRs) & 169 & 169 & 169 & 169 & 169 & 169 & 169 & 169 & 169 \\
\hline Quota (millions of US\$) & 267 & 259 & 260 & 259 & 259 & 258 & 258 & 258 & 258 \\
\hline Gross official reserves (millions of US\$) & 4,329 & 4,388 & 4,494 & 4,671 & 4,815 & 4,999 & 5,123 & 5,250 & 5,381 \\
\hline GDP (millions of US\$) & 18,243 & 17,326 & 18,867 & 19,707 & 20,785 & 22,107 & 23,447 & 24,868 & 26,375 \\
\hline U.S. dollars per SDR & 1.58 & 1.53 & 1.54 & 1.53 & 1.53 & 1.53 & 1.52 & 1.52 & 1.52 \\
\hline
\end{tabular}




\begin{tabular}{|c|c|c|c|c|c|c|}
\hline \multicolumn{7}{|c|}{$\begin{array}{c}\text { Table 11a. Bosnia and Herzegovina: Gross Financing Requirements 2013-18 } \\
\text { (In millions of euros) }\end{array}$} \\
\hline & 2013 & 2014 & 2015 & 2016 & 2017 & 2018 \\
\hline Financing requirements & 1,804 & 1,802 & 1,723 & 1,699 & 1,819 & 1,505 \\
\hline Current account deficit & 1,245 & 1,186 & 1,152 & 1,088 & 1,045 & 977 \\
\hline Amortization & 559 & 616 & 571 & 612 & 774 & 528 \\
\hline Government & 327 & 354 & 277 & 284 & 407 & 109 \\
\hline Other & 232 & 263 & 294 & 327 & 367 & 419 \\
\hline Financing & 1,528 & 1,628 & 1,722 & 1,699 & 1,819 & 1,504 \\
\hline Capital transfers & 190 & 195 & 201 & 207 & 214 & 221 \\
\hline FDI & 347 & 304 & 317 & 329 & 342 & 355 \\
\hline Net bank financing & 20 & 131 & 134 & 142 & 151 & 150 \\
\hline Foreign loans & 632 & 645 & 665 & 613 & 620 & 610 \\
\hline Government & 342 & 325 & 336 & 285 & 285 & 285 \\
\hline Other & 290 & 320 & 329 & 328 & 335 & 325 \\
\hline Gross international reserves $(+=$ increase $)$ & 73 & 159 & 137 & 169 & 125 & 348 \\
\hline Other & 412 & 512 & 543 & 576 & 616 & 515 \\
\hline Financing gap & 276 & 174 & 0 & 0 & 0 & 1 \\
\hline IMF & 176 & 98 & 0 & 0 & 0 & 0 \\
\hline EU & 100 & 0 & 0 & 0 & 0 & 0 \\
\hline World Bank & 0 & 76 & 0 & 0 & 0 & 1 \\
\hline \multicolumn{7}{|c|}{$\begin{array}{c}\text { Table 11b. Bosnia and Herzegovina: Gross Financing Requirements 2013-18 } \\
\text { (In percent of GDP) }\end{array}$} \\
\hline & 2013 & 2014 & 2015 & 2016 & 2017 & 2018 \\
\hline Financing requirements & 12.7 & 12.0 & 10.8 & 10.0 & 10.0 & 7.7 \\
\hline Current account deficit & 8.7 & 7.9 & 7.2 & 6.4 & 5.7 & 5.0 \\
\hline Amortization & 3.9 & 4.1 & 3.6 & 3.6 & 4.3 & 2.7 \\
\hline Government & 2.3 & 2.4 & 1.7 & 1.7 & 2.2 & 0.6 \\
\hline Other & 1.6 & 1.8 & 1.8 & 1.9 & 2.0 & 2.2 \\
\hline Financing & 10.7 & 10.9 & 10.8 & 10.0 & 10.0 & 7.7 \\
\hline Capital transfers & 1.3 & 1.3 & 1.3 & 1.2 & 1.2 & 1.1 \\
\hline FDI & 2.4 & 2.0 & 2.0 & 1.9 & 1.9 & 1.8 \\
\hline Net bank financing & 0.1 & 0.9 & 0.8 & 0.8 & 0.8 & 0.8 \\
\hline Foreign loans & 4.4 & 4.3 & 4.2 & 3.6 & 3.4 & 3.1 \\
\hline Government & 2.4 & 2.2 & 2.1 & 1.7 & 1.6 & 1.5 \\
\hline Other & 2.0 & 2.1 & 2.1 & 1.9 & 1.8 & 1.7 \\
\hline Gross international reserves $(+=$ increase $)$ & 0.5 & 1.1 & 0.9 & 1.0 & 0.7 & 1.8 \\
\hline Other & 2.9 & 3.4 & 3.4 & 3.4 & 3.4 & 2.7 \\
\hline Financing gap & 1.9 & 1.2 & 0.0 & 0.0 & 0.0 & 0.0 \\
\hline IMF & 1.2 & 0.7 & 0.0 & 0.0 & 0.0 & 0.0 \\
\hline EU & 0.7 & 0.0 & 0.0 & 0.0 & 0.0 & 0.0 \\
\hline World Bank & 0.0 & 0.5 & 0.0 & 0.0 & 0.0 & 0.0 \\
\hline
\end{tabular}




\begin{tabular}{|c|c|c|c|c|c|c|c|c|}
\hline \multicolumn{9}{|c|}{$\begin{array}{c}\text { Table 12. Bosnia and Herzegovina: Financial Soundness Indicators, 2008-12 } \\
\text { (In Percent) }\end{array}$} \\
\hline & 2008 & 2009 & 2010 & 2011 & \multicolumn{4}{|c|}{2012} \\
\hline & & & & & Mar & Jun & Sep & Dec \\
\hline \multicolumn{9}{|l|}{ Capital } \\
\hline Tier 1 capital to risk-weighted assets (RWA) & 12.0 & 12.4 & 12.6 & 13.6 & 14.3 & 14.1 & 14.1 & 14.1 \\
\hline Net capital to RWA & 16.3 & 16.1 & 16.2 & 17.2 & 17.5 & 16.7 & 16.8 & 17.0 \\
\hline \multicolumn{9}{|l|}{ Quality of assets ${ }^{1}$} \\
\hline Nonperforming loans to total loans & 3.1 & 5.9 & 11.4 & 11.8 & 12.1 & 12.7 & 12.7 & 13.5 \\
\hline Nonperforming assets (NPAs) to total assets & 2.2 & 3.9 & 8.1 & 8.8 & 9.3 & 9.7 & 9.7 & 10.3 \\
\hline NPAs net of provisions to tier 1 capital & 14.3 & 25.9 & 46.1 & 26.1 & 25.9 & 28.7 & 28.9 & 30.4 \\
\hline Provision to NPAs & 37.9 & 34.6 & 40.8 & 68.2 & 68.1 & 67.4 & 66.6 & 67.4 \\
\hline \multicolumn{9}{|l|}{ Profitability } \\
\hline Return on assets ${ }^{2}$ & 0.4 & 0.1 & -0.6 & 0.7 & 0.7 & 0.8 & 1.1 & 0.6 \\
\hline Return on equity ${ }^{2}$ & 4.3 & 0.8 & -5.5 & 5.9 & 6.0 & 6.5 & 8.7 & 5.0 \\
\hline Net interest income to gross income & 60.6 & 61.5 & 60.1 & 63.8 & 65.5 & 64.2 & 63.6 & 63.7 \\
\hline Noninterest expenses to gross income & 90.5 & 97.4 & 109.0 & 86.3 & 83.2 & 81.0 & 81.1 & 87.2 \\
\hline \multicolumn{9}{|l|}{ Liquidity } \\
\hline Liquid assets to total assets & 30.0 & 30.9 & 29.0 & 27.3 & 24.7 & 24.7 & 24.9 & 25.4 \\
\hline Liquid assets to short- term financial liabilities & 51.8 & 52.9 & 49.7 & 46.7 & 42.3 & 43.0 & 43.5 & 44.1 \\
\hline Short- term financial liabilities to total financial liabilities & 65.4 & 66.2 & 66.9 & 68.4 & 69.0 & 67.7 & 67.4 & 67.9 \\
\hline \multicolumn{9}{|l|}{ Foreign exchange risk } \\
\hline Foreign currency and indexed loans to total loans & 73.3 & 73.9 & 70.0 & 66.7 & 63.3 & 63.5 & 63.7 & 63.1 \\
\hline Foreign currency liabilities to total financial liabilities & 69.5 & 69.2 & 67.0 & 66.0 & 65.4 & 67.0 & 66.5 & 65.2 \\
\hline Net open position & 6.2 & 1.7 & 4.4 & 16.1 & 6.4 & 8.3 & 6.4 & 5.4 \\
\hline \multicolumn{9}{|c|}{$\begin{array}{l}\text { Source: CBBH. } \\
{ }^{1} \text { Prior to 2010, assets classified as loss, alongside the provisions made against them, were held off-balance sheet by banks in BiH. } \\
\text { This lowered the reported NPL ratios and coverage of nonperforming loans by provisions. Starting with the December } 2010 \text { data, } \\
\text { the RS Banking Agency requires banks to record on-balance sheet the "loss" loans and related accrued interest and provisions, } \\
\text { resulting in a structural break in the series. The Federation Banking Agency is planning to enforce the same methodology } \\
\text { starting in December } 2011 .\end{array}$} \\
\hline
\end{tabular}




\section{APPENDIX I. SUPPLEMENTARY LETTER OF INTENT}

Sarajevo and Banja Luka, Bosnia and Herzegovina

April 23, 2013

Ms. Christine Lagarde

Managing Director

International Monetary Fund

Washington, D.C. 20431

Dear Ms. Lagarde:

1. The Stand-By Arrangement (SBA) for Bosnia and Herzegovina ( $\mathrm{BiH})$ that was approved in September 2012 by the Executive Board of the International Monetary Fund (IMF) continues to provide us with a valuable framework for our economic policies. We remain committed to implementing the policies described in our Letter of Intent dated September 11, 2012, as well as to the policies described in our supplementary Letter of Intent of December 6, 2012. This supplementary Letter of Intent provides information on our efforts and achievements since the completion of the first review under the arrangement in December 2012, as well as on additional policy measures we plan to undertake during the remainder of 2013 to help ensure that the objectives of the SBA will be met.

2. The overall economic situation remains difficult. After two years of modest recovery, real GDP is estimated to have contracted in 2012 by close to 1 percent. With the outlook for Europe remaining subdued and limited room for domestic stimulus, modest growth is projected for 2013: we expect that growth in $\mathrm{BiH}$ will remain below 1 percent this year. Inflation, meanwhile, continues to be well contained at close to 2 percent, despite higher food and energy prices, with core inflation low at around $1 / 2$ percent. Inflation is expected to remain low in 2013. Unemployment, however, is very high and continues to be a major concern. 


\section{Program Implementation}

3. Our policies are well on track to meet program objectives. All quantitative performance criteria for end-December 2012 on the budget balances of the Institutions of $\mathrm{BiH}$ and the central governments of the Federation and the Republika Srpska were met with comfortable margins. As overall revenues were slightly less than forecasted, this outcome reflects our ongoing efforts to contain public spending. Similarly, we did not contract or guarantee any new non-concessional short-term external debt, nor did we accumulate any external payment arrears, neither through endDecember 2012, nor in the first quarter of 2013. However, we face considerable difficulties in monitoring the observance of the performance criterion on the non-accumulation of domestic arrears, because of weaknesses and delays in reporting by lower levels of government. While we can report that the Institutions of $\mathrm{BiH}$ and the central governments of the Federation and the Republika Srpska did not see an increase in domestic arrears in the period through end-December 2012, data collection for the lower levels of government, extra-budgetary funds, and road and highway funds for end-2012 is yet to be finalized. This process involves in many cases the verification of the balance sheets and financial statements-a process that is complicated by a lack of a sufficient number of trained staff-and this process is not expected to be completed before end-May. Going forward, to avoid these delays, we request a modification of this performance criterion so that it applies only to the central governments of the Federation and the Republika Srpska and to the Institutions of $\mathrm{BiH}$. As we remain committed to ensure the integrity of our public finances, we would also like to set indicative targets for the changes in the stock of "other accounts payable" for the general governments of the Federation and the Republika Srpska, for which information can be directly derived from our harmonized reporting template. In addition, we will seek further technical assistance from the IMF to assist us with improving reporting by lower levels of government.

4. Good progress has been made toward fiscal consolidation. Although final end-2012 data for the general government will only become available in the coming months, based on the information available to date we are confident that the overall deficit was below our target of 3 percent of GDP. Available information also suggests that the indicative target for the balance of the general government-which excludes foreign financed projects—is also likely to have been met. Fiscal consolidation will continue in 2013, with the 2013 budgets that were adopted in December being consistent with a further reduction in the overall deficit to 2 percent of GDP. 
5. We have also made steady progress in advancing our structural reform agenda. We have continued to adhere to the Currency Board Arrangement (CBA) and refrained from introducing new privileged or special rights for retirement-both continuous structural benchmarks-and most of the structural benchmarks through end-December 2012 were observed, albeit in several cases with some delay and some are still awaiting parliamentary approval. These delays largely stemmed from the longer-than-expected time it took to obtain parliamentary approval where this was needed, in part reflecting a heavy legislative agenda and the need for adequate consultative processes. More specifically:

- The consolidated general government accounts for end-September 2012 have been published on the website of the Institutions of $\mathrm{BiH}$ and we expect to publish the accounts for end-December 2012 in May 2013;

- The eligibility audits of recipients of war benefits are continuing and the results of these audits through end-2012 have been published by both entities;

- Payments of accrued amounts to decommissioned army personnel whose entitlements were repealed at the State level in May 2012 have been made;

To facilitate cooperation with foreign bank supervisors, the Banking Agency law was amended in the Federation to bring the treatment of confidential information in line with EU practices, and this process is expected to be completed in the Republika Srpska by end-June 2013;

- To strengthen the bank resolution framework, amendments to the banking laws of both entities to limit the duration of provisional administration to one year with a possible six month extension have been submitted to the respective parliaments. Parliamentary approval is expected by end-June 2013;

- The Law on Financing of the Institutions of $\mathrm{BiH}$ has been amended to secure that external debt service can continue regardless of the status of approval of the budget and to require the Institutions of $\mathrm{BiH}$ and its ministries to ensure that sufficient balances are accumulated and available in the relevant accounts held with the Central Bank of Bosnia and Herzegovina $(\mathrm{CBBH})$ to service the foreign debt. 
- The Ministry of Finance and Treasury of $\mathrm{BiH}$, the Ministry of Finance of the Federation of $\mathrm{BiH}$, the Ministry of Finance of the Republika Srpska, the Indirect Taxation Authority (ITA), and the $\mathrm{CBBH}$ signed a Memorandum of Understanding to regulate the disbursements from and servicing of all related obligations to the IMF. This memorandum specifies that all disbursements under the SBA will be exchanged into domestic currency by the $\mathrm{CBBH}$ and deposited in the subaccounts of the entities at the $\mathrm{CBBH}$, and provides the $\mathrm{CBBH}$ with a standing authorization to execute debt obligations vis-à-vis the IMF as they fall due using the designated IMF payment account and the Indirect Tax Authority accounts designated for debt servicing.

A new law on privileged pension has been adopted in the Federation (a prior action for this review). This law now provides a comprehensive system that is financially sustainable and socially fair. The new law ensures the separation of the contributory portion of pensions from the privileged portion: pension fund obligations cover only pension entitlements based on years of contributions and age, while the additional amounts stemming from military service will be paid from the central government budget. The new law also harmonized privileged pension levels across similar groups and, more importantly, substantially reduced the average level of privileged pensions, bringing it much closer to the average level of contributory pensions. Moreover, the new law introduced large penalties for early retirement. As these changes ensure that the costs to the budget would remain well within the maximum envelope of KM 197 million, the revisions allowed for an expansion of the number of beneficiaries to ensure fair treatment of older veterans and veterans with disabilities. The new law furthermore requires that existing recipients of privileged pensions who have not already been audited go through a process of re-certification to confirm their eligibility within a period of four months as of the date of effectiveness of the new law, and no applications for any privileged pensions will be accepted after December 1, 2013 (with the exception of those qualifying under Articles 4.1 and 4.3 of the new law). Moreover, no further new categories of privileged pensions will be introduced following the adoption of this law (a continuous structural benchmark). Going forward, the new law specifies that the increase in benefit levels will be less than the rate of consumer price inflation to achieve further convergence with the average level of contributory pensions, while the law also ensures the continued use of the rationing coefficient to guarantee that privileged pension 
payments financed from the budget will not exceed the amount allocated in the central government budget in a particular year.

\section{Further Reforms}

6. A draft comprehensive pension reform strategy has been prepared in the Federation. This strategy is aimed at ensuring the financial sustainability of the pension system, including by raising the retirement age, increasing the number of contributors, and discouraging early retirement. The draft strategy is being discussed with stakeholders and is expected to be finalized and submitted to parliament-with the inclusion of an action plan—by end-May 2013.

7. A new budget system law has been adopted in the Republika Srpska, which introduced penalty clauses for undertaking commitments that exceed the level of budget allocations. A new law on budgets is also being prepared in the Federation with technical assistance from the IMF. A first draft has been discussed with IMF staff and we will update the draft in line with IMF staff recommendations, particularly to: (i) strengthen the intergovernmental consultation and coordination process; (ii) improve the medium-term budgeting process; (iii) ensure the inclusion of financial plans and outcomes of public companies and extra-budgetary funds as annexes to the annual budget documents; (iv) improve cash management procedures; and (v) strengthen internal and external audit provisions. As this will require more time, we expect the new law to be adopted by end-May 2013 (originally a structural benchmark for end-March). The Federation finance ministry will also expand its consolidation unit and seek additional assistance to train its staff and that of lower levels of government. The ministry will also seek further technical assistance from the IMF to strengthen its cash management.

8. We are moving ahead with strengthening our coordination in the area of tax administration. The Governing Board of the ITA approved new coefficients for the distribution of indirect tax revenues in March and will continue to do so quarterly, in line with the existing legal regulations and procedures. We will secure the functioning of the Final Consumption Unit under the Governing Board by staffing it with representatives of both entities by end-May 2013. The Governing Board will also approve a reorganization of the ITA by amending the Rulebook on Internal Organization and Systematization of the ITA with a view to targeting its resources-within its current budget envelope and existing number of employees - to the Large Taxpayer Unit and establish strategy and risk 
analysis units, with the latter also focusing on the detection and coordination of activities for the prevention of VAT fraud. The four tax agencies (ITA, FTA, RSTA, and BDTA) expect to sign the Memorandum of Understanding on the exchange of taxpayer information as planned by end-May. The information sharing of taxpayer records will start in the following months and will be comprehensive, unfettered, and automated. In particular, the FTA, RSTA, and BDTA will have permanent access to each other's income tax and social contributions data, as well as the ITA's VAT, excise, and customs data. Conversely, ITA auditors will have permanent access to taxpayer data held by the FTA, RSTA, and BDTA for purposes of undertaking VAT and customs post clearance audits.

9. Increased efforts are underway to improve the financial soundness of the Health Fund in the Republika Srpska. The collection base has been broadened to capture farmers and temporary employment contracts, and the transfer from the budget has been increased. Further efforts will also be made to collect contribution arrears. To contain health care spending, we will adjust the network of health centers and their staffing in line with our Primary Health Care Strategy for 2013. In addition, we will: (i) reduce the wage bill of the Health Insurance Fund by approximately KM 2.5 million in 2013; (ii) reduce the level of sick leave compensation for sick leave longer than 30 days by 10 percent; (iii) reduce the list of covered medications and orthopedic aids; and (iv) reduce the coverage of medical treatment outside Republika Srpska.

10. In the financial sector, to further increase our crisis preparedness and contingency planning, the $\mathrm{CBBH}$ and the Banking Agencies signed the joint Memorandum of Understanding formalizing stress-testing procedures in March. The identification of financial institutions that are considered systemically important is also almost completed. The list of systemically important banks will serve as a platform to monitor developments in the financial sector more closely and discuss possible risks. Amendments to the law governing the Deposit Insurance Agency have been prepared in line with Fund recommendations and have been submitted to parliament. We will determine further steps to enhance our crisis preparedness, as well as steps to improve the resolution framework for non-performing loans following technical assistance from the IMF. To update and harmonize our legal and regulatory framework on banks with EU legislation, both entities, i.e., the entity finance ministries and banking agencies, and the Deposit Insurance Agency will coordinate work and take the necessary steps, with assistance of the IMF, to prepare new laws on credit institutions by mid2014. 
11. With high unemployment, and particularly youth unemployment, a major concern, we recognize there is need to make Bosnia and Herzegovina a more attractive place to invest and create more jobs. We are already preparing a one-stop process for business registration in Republika Srpska and a new law on companies in the Federation, to make it easier to start and operate a business. We have also started the consultative process with trade unions and employers' organizations to revisit labor legislation with a view to increase job creation. We expect to adopt new labor laws in the Federation and the Republika Srpska to this effect by end-2013. We have made progress in amending our rules and procedures covering food and animal safety to align these with EU requirements and expect to complete this process in the coming months, to avoid the disruption of exports of agricultural products to neighboring countries acceding to the EU.

\section{Program Modalities}

12. We believe that our economic program continues to be on course, despite a difficult environment, and that our policies set forth in our Letter of Intent of September 11, 2012, and supplemented by the policies described in the supplementary Letter of Intent of December 6, 2012 and this supplementary letter are adequate to achieve the objectives of our program. We stand ready, however, to take any additional measures that may be needed to achieve the objectives of our economic program. We will consult with the IMF on the adoption of additional policy measures and in advance of any revision to the policies contained in our economic program, in accordance with IMF policies on such consultation. We will continue to provide IMF staff with the necessary information for assessing progress in implementing our program and will maintain a close policy dialogue with IMF staff.

13. As the consideration of this second review was delayed slightly in order for the prior action to be implemented, we request the Executive Board to approve waivers of applicability of the endMarch 2013 performance criteria on fiscal balances and domestic arrears, for which data are not yet available and for which there is no evidence that these were not observed. We also request the IMF's Executive Board to approve the modification of the performance criterion on the non-accumulation of domestic arrears for end-June 2013 and going forward so that it applies only to the central governments of the Federation and the Republika Srpska and to the Institutions of $\mathrm{BiH}$, while establishing indicative targets for the general governments of the Federation and the Republika Srpska on changes to the stock of other accounts payable. We furthermore request the Executive 
Board to complete the second review under the SBA and approve the third purchase under the arrangement in the amount of SDR 33.82 million.

14. We authorize the IMF to publish this Letter of Intent and its attachments, as well as the related staff report on the IMF's website following consideration of our request by the IMF's Executive Board.

/s/

Vjekoslav Bevanda

Chairman

of the Council of Ministers

Bosnia and Herzegovina

/s/

Nikola Špirić

Minister of Finance

and Treasury of

Bosnia and Herzegovina

/s/

Kemal Kozarić

Governor

Central Bank of Bosnia and Herzegovina /s/

Nermin Nikšić

Prime Minister

Federation of Bosnia

and Herzegovina

/s/

Ante Krajina

Minister of Finance

Federation of Bosnia

and Herzegovina /s/

Željka Cvijanović

Prime Minister

Republika Srpska

/s/

Zoran Tegeltija

Minister of Finance

Republika Srpska 


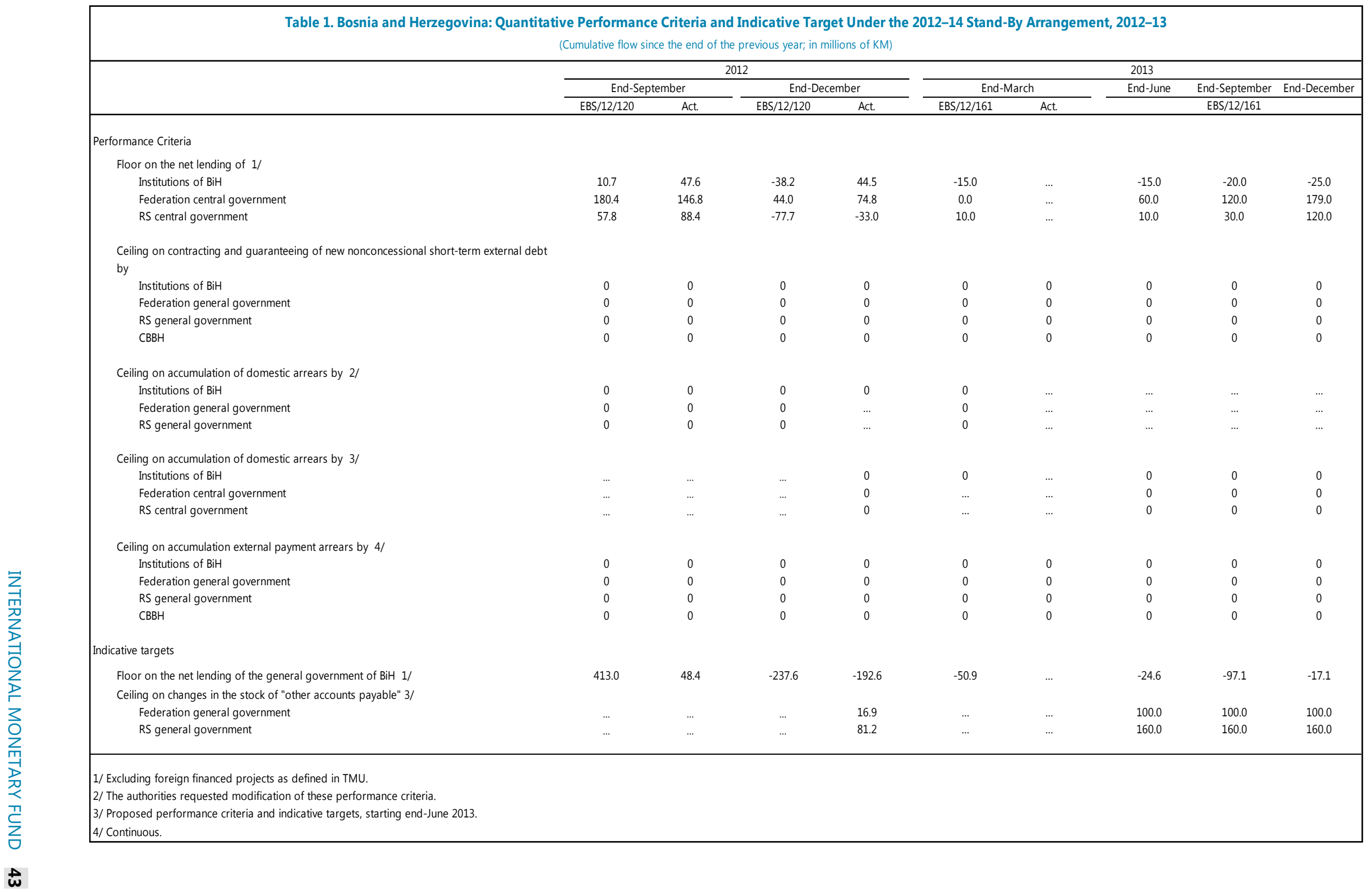


Table 2. Bosnia and Herzegovina: Structural Conditionality

Actions

Prior Action for Board consideration of the second review

1 Adopt a new law on privileged pensions in the Federation in line with IMF staff recommendations

\section{Structural benchmarks}

1 Continue to adhere to the Currency Board Arrangement as constituted under the law

2 Refrain from introducing new privileged or special rights for retirement

3 Publish on the web site of the Institutions of $\mathrm{BiH}$ quarterly consolidated general government accounts with a 6 week lag

4 Carry out eligibility audits for war benefit recipients; publish results (quarterly within 4 weeks after the end of each quarter) of audits (Entities)

5 Pay obligations accrued through May 2012 arising from early retirement provisions under the Law on Service in the Armed Forces of BiH

6 Amend the Law on Financing of the Institutions of $\mathrm{BiH}$ to allow for continued servicing of foreign debt in the absence of an adopted budget

7 Amend the banking law in the Federation to limit provisional administration to one year with a possible six month extension

8 Amend the banking law in the RS to limit provisional administration to one year with a possible six month extension

9 Amend the legal frameworks related to the treatment of confidential information in the Federation and the RS to align them with EU requirements

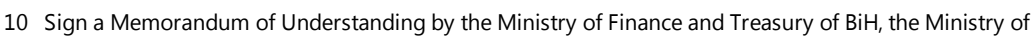
Finance of the Federation, the Ministry of Finance of the $\mathrm{RS}$, and the $\mathrm{CBBH}$, which will regulate the disbursements from and servicing of all related obligations to the IMF

11 Adopt a new law on budget in the Federation that improves data reporting and enhancing control over lower level governments, extra-budgetary funds, and public companies

12 Submit to the BiH Parliament a revised law governing the Deposit Insurance Agency along the lines specified in $\llbracket 28$ of the LOI of September 11, 2012

13 Sign a joint Memorandum of Understanding by the four tax agencies (ITA, FTA, RSTA, and BDTA) on data exchange to further improve the exchange of information

14 Establish a one-stop shop process for business registration in RS

15 Amend legislation in the RS to eliminate the take-home pay protection for public sector employees
Continuous

Met

Continuous

Quarterly

Quarterly

End-December 2012

End-December 2012

End-December 2012

End-December 2012

End-December 2012

End-December 2012

End-March 2013

End-March 2013

End-May 2013

End-September 2013

End-December 2013
Met in September; not met in December

Met with delay

Met

Met with delay

Not met; reset to endJune 2013

Not met; reset to endJune 2013

Not met, reset to endJune 2013

Met with delay

Not met, reset to endMay 2013

Met 


\section{ATTACHMENT 1. ADDENDUM TO THE TECHNICAL MEMORANDUM OF UNDERSTANDING ON DEFINITIONS AND REPORTING UNDER THE 2012-14 STAND-BY ARRANGEMENT}

The Technical Memorandum of Understanding (TMU) on Definitions and Reporting Under the 2012-14 Stand-By Arrangement dated September 11, 2012 and the Addendum to the TMU dated December 6, 2012 shall remain in effect except for the amendments below:

1. In Section E, references to "Federation and Republika Srpska General Governments" shall be replaced with "Federation and Republika Srpska Central Governments."

2. A new Section $F$ shall be introduced, reading:

"F. Ceiling on changes in the stock of "other accounts payable" by the Federation of Bosnia and Herzegovina and Republika Srpska General Governments (Indicative Target)

\section{Definition}

31. The indicative target established on the ceiling on changes in the stock of other accounts payable contemplates (i) a KM 100 million ceiling for the Federation of Bosnia and Herzegovina general government and (ii) a KM 160 million ceiling for the Republika Srpska general government, on the accumulation of other accounts payable compared to the balance as of December 31 of the previous year. The accumulation of other accounts payable (Ostale obaveze) is defined as the sum of change in float and change in arrears. These can arise from any expenditure item, including transfers to individuals, debt service, wages, pensions, energy payments, and goods and services.

\section{Application of the indicative target}

32. The respective ceilings on changes in the stock of other accounts payable apply to obligations of the Federation of Bosnia and Herzegovina and of the Republika Srpska general governments as defined above. This target will be measured quarterly on the basis of end-of-quarter data. Thus, if at the end of any given quarter any of the two governments exceed their corresponding ceiling on changes in the stock of other accounts payable compared to the balance of the same government's other accounts payable as of December 31 of the previous year, the indicative target will be missed.

33. Reporting requirements: Data on "other accounts payable" (Ostale obaveze) for the general government will be contained in the data on quarterly general government 
execution, including revenues, expenditure and financing, to be provided by the Ministries of Finance of the respective Entities no later than six weeks after the end of each quarter."

3. Paragraphs $31,32,33$, and 34 shall be renumbered $34,35,36$, and 37 respectively. 
May 6, 2013

\section{IMF Completes Second Review under the Stand-By Arrangement with Bosnia and Herzegovina and Approves €39 Million Disbursement}

The Executive Board of the International Monetary Fund (IMF) today completed the second review of Bosnia and Herzegovina's (BiH's) economic performance under a program supported by a 24-month Stand-By Arrangement (SBA). The completion of the review enables the disbursement of an amount equivalent to SDR 33.82 million (about $€ 39$ million, or US\$51.1 million), bringing total disbursements under the program to an amount equivalent to SDR 135.28 million (about $€ 155.9$ million, or US\$204.4 million).

The SBA with BiH was approved on September 26, 2012 (see Press Release No. 12/366) in an amount equivalent to SDR 338.2 million (about $€ 389.7$ million, or US\$511 million).

In completing the second review, the Executive Board also approved requests for the waiver of applicability of end-March 2013 performance criteria for which data are not yet available, and for the modification of the performance criterion on the non-accumulation of domestic arrears to align it better with the authorities' fiscal reporting framework and to take into account delays in data reporting by lower levels of government.

Following the Executive Board's discussion, Ms. Minouche Shafik, Deputy Managing Director and Acting Chair, stated:

"BiH's continued good progress under the program is testament to the authorities' commitment to prudent policies amid a very challenging domestic and external environment. Fiscal consolidation remains on track, while sound financial sector policies are mitigating risks. The Fund-supported program continues to provide a valuable anchor for the authorities' economic policies.

"Remaining within the spending envelopes in the 2013 budgets will be crucial to ensure sustained fiscal consolidation, leaving no room for fiscal stimulus. Nonetheless, a slightly slower pace of fiscal adjustment might be temporarily warranted should revenues disappoint in the event of weaker-than-expected growth. 
"Achieving medium-term fiscal sustainability will require moving ahead with fiscal structural reforms to generate structural savings. Reforms of war-related benefit programs, adopted in the Republika Srpska in early 2012 and now also in the Federation, are welcome and bold steps in this direction. Other key areas for reform include streamlining the size and structure of the government and reducing the cost of health care. Additional efforts to improve the quality and timeliness of fiscal reporting by lower levels of government are also critical.

"Progress made in strengthening banking supervision, including by formalizing stress testing procedures and identifying systemically important institutions, should enhance the authorities' risk assessment toolkit, thereby promoting financial stability. Nevertheless, the rise in non-performing loans (NPLs) warrants continued close monitoring of banks' health. The ongoing review of the NPL resolution framework will help define measures to enable banks to strengthen their balance sheets.

“Reaching BiH's growth potential will require further structural reforms to enhance competitiveness and create jobs. Improving the business environment and labor market flexibility are key to a thriving private sector and to making $\mathrm{BiH}$ an attractive place to invest." 


\section{Statement by Mr. Snel and Mr. Friedman on Bosnia and Herzegovina}

May 6, 2013

\section{Background}

The economy of Bosnia and Herzegovina $(\mathrm{BiH})$, which is strongly connected to Europe through trade and financial channels, continues to pay a high price for the tough conditions there. Following low demand in its trading partners, exports slumped in 2012 by 7.5 percent, dragging the whole economy down to an export-led recession that resulted in a contraction of economic activity by 0.7 percent. On top of the negative external conditions, fiscal consolidation, which was essential for maintaining debt sustainability, applied additional downward pressure on economic activity. The share of government spending in GDP fell by almost a whole percentage point, off-setting completely the automatic stabilizers. The negative output growth led unfortunately to an additional increase in the unemployment rate, which currently is at 28 percent. Notwithstanding these negative developments, $\mathrm{BiH}$ continues to make good progress with respect to its economic plan.

\section{Fiscal Policy}

The bright side is that although growth has so far been disappointing, and falls short when compared to the original forecast when the program was designed, fiscal consolidation, which is an important part of the program, is taking place at a faster pace than initially envisaged. The preliminary figures for 2012 point to a public deficit of 2.5 percent, while the program was designed to achieve a 3.0 percent deficit. Tight control over expenditures, which led to a contraction of 1.8 percent of government consumption in real terms, helped to stabilize the deficit at about the 2011 level. Consolidation took place at all levels of government. All quantitative performance criteria for end-December 2012 on the budget balances of the state-level Institutions of $\mathrm{BiH}$ and its entities were met.

The deficit resulted in an increase in the level of public debt to about 44 percent of GDP. Although not a high level when compared to its peers, the authorities are fully aware of the importance of bringing it down. Going forward, the 2013 budgets are designed to bring the deficit down to 2.0 percent, and the authorities are ready to take additional steps if it turns out that the assumptions under which the budget was designed - modest recovery in 2013 - are too optimistic.

\section{Structural reforms}

Bosnia and Herzegovina continues to make progress with respect to its program reform agenda. This is true for the entities of $\mathrm{BiH}$ - the Federation of $\mathrm{BiH}$ and Republika Srpska - as well as for the state-level institutions of $\mathrm{BiH}$ - the Council of Ministers, and the Central Bank of $\mathrm{BiH}$. 
The entities of $\mathrm{BiH}$ and the institutions of $\mathrm{BiH}$ continue to coordinate closely their policies, and this enabled the completion of a series of reforms. The fiscal council continued to meet and promote coordination at the national level. The fruits of national coordination include:

- $\quad$ a better banking resolution framework which is underway;

- A law that enables uninterrupted foreign debt servicing even in the absence of an adopted budget;

- $\quad$ a signed MOU between all the levels of government that safeguards debt servicing to the Fund;

- $\quad$ sharing taxpayer information to be started soon by the entities of $\mathrm{BiH}$, a step which is expected to improve tax collection by reducing the possibility of tax avoidance;

- the distribution of previous, indirect tax revenues between the entities of $\mathrm{BiH}$, an issue which was unsettled for some time;

- $\quad$ and an MOU signed by the $\mathrm{CBBH}$ and the Banking Agencies that will enable joint stress-testing.

\section{The entities of BiH}

Since the Approval of the SBA in September 2012 and the completion of the first review in December 2012, the Federation of BiH and Republika Srpska have made substantial progress with respect to several issues.

The Federation of $\mathrm{BiH}$ completed a long and complicated process of overhauling its Privileged Pension Law (PPL), a contentious, politically-difficult issue. The PPL is one of the major deliverables of the program and a cornerstone and a prior action of this second review. The new law achieves several important goals. From a public finance perspective, the law caps the total expenditure on privileged pensions this year and ensures that the allowances will increase by less than the CPI. These two features ensure that total expenditure on privileged pension is sustainable and that the fiscal cost of the PPL as a share of GDP will decrease over time. In addition, the "privilege" part of the PPL, i.e. that part that is not linked to contributions, will be financed from the general budget and not by the pension fund, thereby contributing to its sustainability.

The new PPL, which was designed in close consultations with the Fund and the World Bank, will cover a larger group of pensioners, but the allowance per person is going to be substantially lower, and new beneficiaries, such as disabled and unemployed war veterans will be receiving a minimum pension. This trade-off allows for a more socially just distribution. 
In addition the Federation of $\mathrm{BiH}$ amended its banking law with respect to the treatment of confidential information, so it now complies with EU standards, and this will make possible a tighter cooperation with foreign supervisors, which is key to financial stability given the structure and ownership of the banking system in $\mathrm{BiH}$.

In Republika Srpska, a new budget system law, which tightens the control of the central government over fiscal expenditure in governmental units, has been adopted. Efforts to contain the increasing costs of health care were taken, including broadening the base of revenue collection. A detailed plan to further consolidate health expenditure will be implemented in the next few months so to create substantial savings in 2013.

\section{Fund Support}

The authorities see the SBA as an important contribution to their economic plan. As before, the SBA increases the credibility of the currency board arrangement, contributes to national coordination, and to the implementation of important policy reforms.

As a result, the commitment of the authorities to the SBA and its timeline is strong, as had been demonstrated during the program approval in September 2012, when rebalanced budgets for $\mathrm{BiH}$ institutions and its entities were legislated late in the fiscal year, and in December 2012, when the 2013 budgets were legislated ahead of the fiscal year for the first time in the post-war period. This strong commitment is now demonstrated by the completion of the required prior actions for this review, some of which were unpopular and politically tough. Without underestimating the risks to the program going forward given the challenging political situation, the track-record of $\mathrm{BiH}$ so far indicates to the authorities' strong ownership.

The authorities of $\mathrm{BiH}$ request the Executive Board to complete the second review under the SBA and to approve waivers of applicability of the end-March 2013 performance criteria on fiscal balances and domestic arrears, for which data are not yet available. As to future reviews, the authorities are requesting to modify the performance criterion on the non accumulation of domestic arrears for end-June 2013 and going forward so that it applies only to the central governments of the entities of $\mathrm{BiH}$ and to the Institutions of $\mathrm{BiH}$, as given the lags in reporting, cannot be monitored in the general government level.

After a long upgrade process, $\mathrm{BiH}$ has finally joined the GDDS, and the authorities would like to thank the Fund for its continued support and efforts on this front. The participation in the GDDS database will allow better monitoring of the BiH economy, both by the authorities and the Fund in the future.

The authorities would like to express their gratitude to the mission chief, Mr. van Rooden, to the resident representative, Mr. Ruben Atoyan, and to the team as a whole, both here in DC and in Sarajevo, for their hard work, helpful advice and excellent report. 